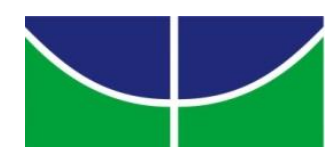

Universidade De Brasília

Instituto De Letras

Departamento de Linguística, Português e Línguas Clássicas

Programa de Pós-Graduação em Linguística

\title{
ASPECTOS PROSÓDICOS NA AQUISIÇÃO DO PORTUGUÊS BRASILEIRO POR AFRICANOS FRANCÓFONOS
}

Eugênia Magnólia da Silva Fernandes 
Eugênia Magnólia da Silva Fernandes

\section{ASPECTOS PROSÓDICOS NA AQUISIÇÃO DO PORTUGUÊS POR AFRICANOS FRANCÓFONOS}

Tese apresentada ao Programa de Doutorado em Linguística do Departamento de Linguística, Línguas Clássicas e Português da Universidade de Brasília como requisito parcial para obtenção do título de Doutora em Linguística.

Orientadora: Profa. Dra. Daniele Marcelle Grannier

Coorientadora: Profa. Dra. Aveliny Mantovam Lima-Gregio 
Eugênia Magnólia da Silva Fernandes

\section{ASPECTOS PROSÓDICOS NA AQUISIÇÃO DO PORTUGUÊS BRASILEIRO POR AFRICANOS FRANCÓFONOS}

Tese apresentada ao Programa de Pós-Graduação em Linguística da Universidade de Brasília como requisito parcial para a obtenção do título de Doutora em Linguística.

Brasília, 20 de março de 2015.

Banca examinadora:

Profa. Dra. Daniele Marcelle Grannier

Universidade de Brasília - LIP

Orientadora

Profa. Dra. Stella Virginia Telles de Araujo Pereira Lima Universidade Federal de Pernambuco

Prof. Dr. Ronaldo Mangueira Lima Júnior Universidade Federal do Ceará

Prof $^{a}$ Dra. Orlene Lúcia de Sabóia Carvalho Universidade de Brasília - LIP

Profa. Dra. Poliana Maria Alves Universidade de Brasília - LIP

Profa. Virginia Andrea Garrido Meirelles Universidade de Brasília - LET 
Aos meus alunos, aprendizes do Português Brasileiro como segunda língua, pelas trocas das infindáveis formas de ver o mundo. 


\section{AGRADECIMENTOS}

Durante o percurso do curso de doutorado, muitos se envolveram e contribuíram para a sua realização. Em primeiro lugar, agradeço à Universidade de Brasília, por ser minha casa acadêmica desde a graduação, há quase 10 anos. Neste lugar, conheci grandes mestres, fiz amizades verdadeiras, partilhei grandes alegrias e também frustrações.

Agradeço à Professora Dra. Daniele Marcelle Grannier, pela oportunidade de me acolher como sua orientanda, por contribuir imensamente com o meu amadurecimento no caminho acadêmico, pela motivação, apoio e calmaria que me invadiam após as orientações, ainda que tivéssemos de driblar o fuso horário na fase final da pesquisa.

Agradeço à Professora Dra. Aveliny Mantovan Lima-Gregio, minha coorientadora, pela ajuda com o programa PRAAT e com o manuseio dos dados da pesquisa, também pela paciência, pelo cuidado e pelas incontáveis horas de orientação a distância.

Agradeço aos professores do Departamento de Linguística, Português e Línguas Clássicas da UnB, pelas contribuições para a minha formação enquanto linguista. Em especial, à Professora Dra. Janaína de Aquino Ferraz e à Professora Dra. Orlene Lúcia de Sabóia Carvalho, grandes inspirações desde os primeiros passos na graduação.

Agradeço às secretarias do PPGL, Ângela e Renata, pelos sorrisos e inúmeras gentilezas.

Agradeço à Professora Dra. Luciana Lucente, criadora do sistema DaTo, por sua paciência e grandes contribuições para esta tese.

Agradeço à CAPES pelo suporte financeiro até o terceiro ano desta pesquisa.

Institucionalmente, agradeço ainda à University of California, em Davis, pelo acolhimento como leitora de língua portuguesa desde abril de 2014. A experiência ímpar de ensinar minha língua materna em outro país trouxe mais fortalecimento às discussões desta tese. Além disso, o acesso à grande parte da literatura discutida neste trabalho só foi possível pela consulta aos acervos dos campi.

Agradeço ao Programa de Ensino e Pesquisa em Português para Falantes de Outras Línguas (PEPPFOL), programa que existiu na Universidade de Brasília até 2012. Foi lá que aprendi o fazer docente e pude fazer perguntas para as pesquisas de mestrado e doutorado. Certamente, a prática que trago hoje, ainda em processo, sempre em processo, é fruto da minha formação no programa. 
Minha gratidão e admiração aos estudantes do programa PEC-G, minha motivação, que contribuíram para a coleta de dados desta pesquisa em várias fases. Dentre eles, estão Carine, Jacques, Jean, Jonathan, Kevin, Michée, Nina, Noel, Peggy e Serge.

Agradeço ao Instituto Cultural de Ensino de Português para Estrangeiros (Icepe), meu filho profissional, por ter permitido que eu continuasse a ser professora de português como segunda língua. O Icepe hoje já caminha sozinho e ameaça alçar voo graças à dedicação, à motivação e ao compromisso das amigas e sócias Camila e Renata.

Não apenas pela chance de ter dado vida ao Icepe, agradeço à minha amiga Camila Almeida por ser referência, para mim, de equilíbrio e sensatez. Parceiras também na vida acadêmica, senti-me, por muitas vezes, segura, acolhida e amada com sua presença.

Agradeço também aos meus amigos pelos momentos de descontração e pela felicidade instantânea ao nosso encontro. Em especial, à querida Suseile, pela admirável dedicação ao seu caminho como pesquisadora, à Juliana, meu par e irmã de amor desde a infância, quem, gentilmente, contribuiu com a revisão deste trabalho.

À minha amiga, irmã e sócia, Renata, agradeço e deixo também aqui a minha admiração. Quando eu não pude, ela foi meus pés para onde precisei ir. Juntas vivemos grandes desafios acadêmicos e pessoais, partilhando momentos de felicidade e frustração. Sem dúvidas, a realização deste trabalho não seria possível sem suas amáveis contribuições.

Agradeço aos meus pais, Maria Eugênia e João (in memoriam), pela educação e o tempo a mim dedicado, ainda que incidentalmente curto para o meu pai. Ver a minha mãe atuar, com amor e dedicação, em sua profissão mudou, certamente, o curso do meu rio. Reconheço que, a cada dia, sou mais semelhante a ela: no nome e na garra.

Agradeço ao meu marido, Pedro, por seu incansável apoio, dedicação, compreensão e amor. Suas contribuições se estenderam à fragmentação dos dados e as discussões estatísticas deste trabalho. 
Tudo, aliás, é a ponta de um mistério, inclusive, os fatos. Ou a ausência deles. Duvida? Quando nada acontece há um milagre que não estamos vendo.

(Guimarães Rosa) 


\section{RESUMO}

A proposta deste estudo foi identificar as interferências das línguas africanas da família nigero-congolesa na aquisição do Português Brasileiro por africanos francófonos. Para responder às perguntas da pesquisa, sete colaboradores contribuíram para a coleta de dados, incluindo um para controle, falante nativo do PB. Falantes de línguas tonais da família nigerocongolesa, esses colaboradores apontaram as línguas usadas com mais frequência no contato com outros falantes, uma vez que todos eles apresentam uma competência multilinguística. $\mathrm{O}$ estudos teóricos acerca das línguas fon, lingala e ewondo evidenciaram o predomínio de sistemas tonais e contrastes significativos no campo segmental em comparação ao PB. A coleta de dados foi baseada na leitura de enunciados para a segmentação e análise acústica das unidades VV (vogal a vogal), determinantes da estrutura rítmica do PB (BARBOSA, 2006). A fragmentação dos enunciados também proporcionou a aplicação de rótulos aos contornos entoacionais com base no sistema DaTo (LUCENTE, 2012), que adota uma perspectiva dinâmica e funcional para os movimentos contínuos de f0 (frequência fundamental). Com base no sistema, foi possível constatar que embora os colaboradores façam marcações de proeminência em pontos próximos de um falante nativo, a variação de fo evidencia discrepâncias. Observou-se que não há distinções significativas no contraste entre os colaboradores por tempo de imersão, mas há dados relevantes no contraste entre os grupos por línguas maternas faladas e pela modalidade dos enunciados (injuntiva, declarativa ou interrogativa). A principal característica que distingue a produção dos colaboradores da estrutura rítmica do PB é a duração das unidades VV, que, para esses sujeitos, alonga-se até mais de 120 milissegundos em comparação ao falante nativo do PB.

Palavras-chave: Aquisição de Segunda Língua; Português Brasileiro para Africanos Francófonos, Entoação; Fonologia. 


\begin{abstract}
The goal of this study was to identify the interferences of the African languages of the family Niger-Congo in the acquisition of Brazilian Portuguese by Francophone Africans. In order to answer the research questions proposed, seven people collaborated for the data collection, including one who served as the control group, a native speaker of Brazilian Portuguese. Since the collaborators, speakers of the tonal languages of the Niger-Congo family, also have a multilingual competency, they pointed to the languages which were used more often while in contact with Brazilian Portuguese speakers. The studies made about the languages Fon, Lingala and Ewondo show the predominance of the tonal system and also significant contrasts in the segmental field in comparison to Brazilian Portuguese. The data collection was based on the reading of statements for the segmentation and acoustical analysis of the VV (vowel to vowel) units, determinants of the rhythmic structure of Brazilian Portuguese (Barbosa, 2006). The fragmentation of the statements also provided the application of labels to the intonation contour based on the DaTo system (Lucente, 2012), which adopts a dynamic and functional perspective for the continuous movements of f0 (fundamental frequency). The DaTo system showed however, that the collaborators make marks of prominence in fragments, in most of the data, close to a native speaker, the variation of f0 shows discrepancy. It was observed that there are no significant distinctions by comparing the collaborators for time of immersion. However, there are relevant data by comparing groups according to their first languages and the type of statement (mandatory, declarative or interrogative). The main characteristic that distinguishes the production of the collaborators of the rhythmic structure of Brazilian Portuguese is the duration of the VV units. Within this group, the VV units stretch even more than 120 milliseconds in comparison with the native speaker of Brazilian Portuguese.
\end{abstract}

Key words: Second Language Acquisition; Brazilian Portuguese for Francophone Africans; Intonation; Phonology. 


\section{SUMÁRIO}

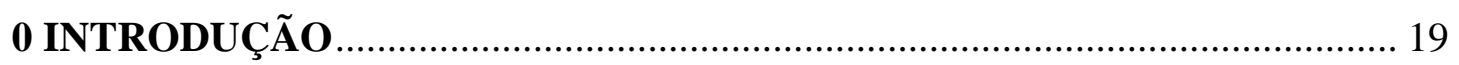

0.1 O ensino de Português como segunda Língua em Brasília................................... 19

$0.2 \mathrm{O}$ mapeamento da Unesco sobre a francofonia..................................................... 20

0.3 As situações de contato e a interferência linguística ........................................... 21

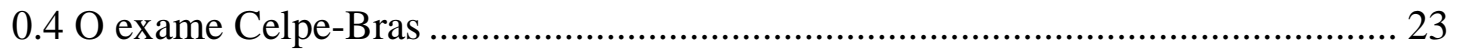

0.5 Objetivos, pergunta de pesquisa e hipóteses ......................................................... 24

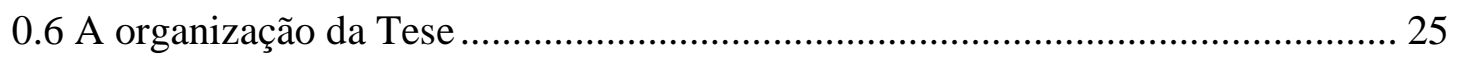

1 AQUISIÇÃO DE SEGUNDA LÍNGUA ….................................................. 26

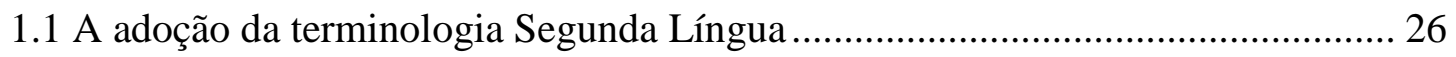

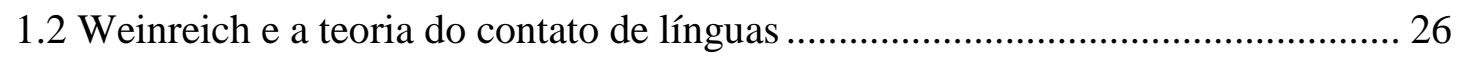

1.3 As contribuições acerca da Análise Contrastiva................................................. 29

1.4 Linguagem e aprendizagem: as discussões atuais acerca da teoria dos sistemas

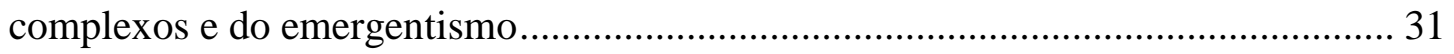

1.4.1 A natureza dos sistemas complexos e dinâmicos ............................................. 32

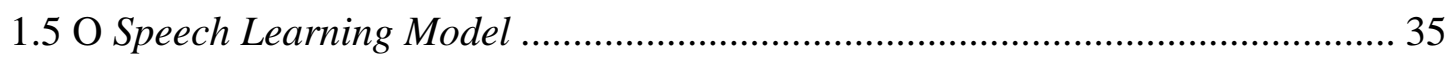

1.6 As teorias de protótipo: o modelo baseado no uso de Bybee ............................... 36

1.7 A aplicação das teóricas dinamicistas para a prosódia ........................................ 38

2 OS ESTUDOS EM FONÉTICA ACÚSTICA …............................................. 39

2.1 O surgimento e a repercussão dos estudos em Fonética Acústica........................ 39

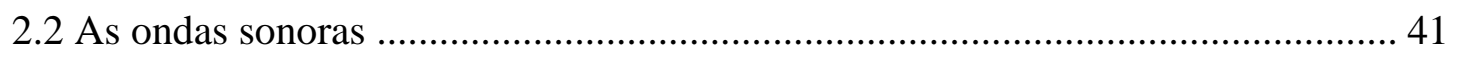

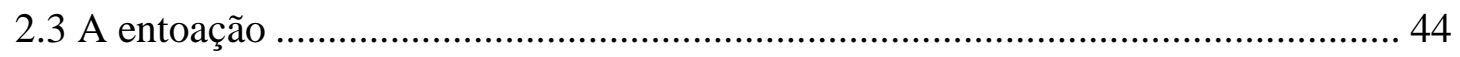

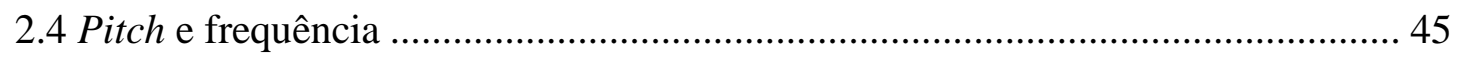

2.5 As discussões acerca da Teoria Métrica Autossegmental (MA) .......................... 47

2.6 Questões tipológicas sobre a tonicidade das línguas ......................................... 49

2.7 A estabilidade dos onsets das vogais na fala: a duração das unidades VV ......... 50

2.8 A entoação no processo de aquisição da linguagem ............................................ 50

3 PANORAMA DAS LÍNGUAS AFRICANAS ................................................. 52

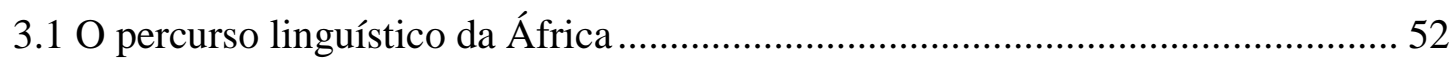




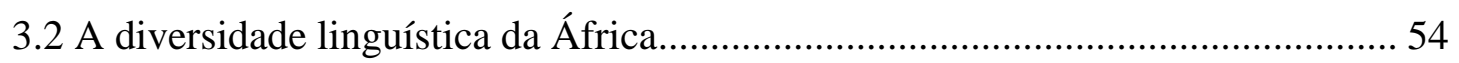

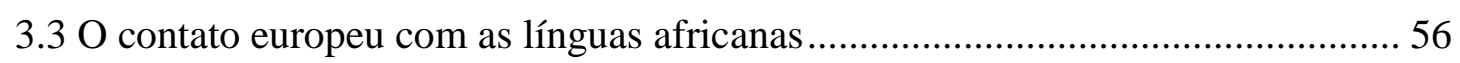

3.4 A classificação tipológica das línguas africanas .................................................... 58

3.4 As línguas africanas mais faladas pelos colaboradores do estudo......................... 62

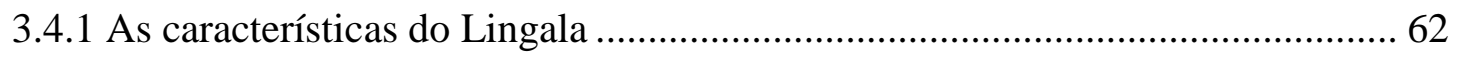

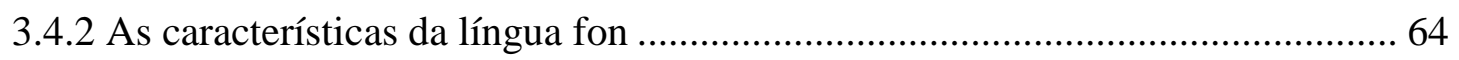

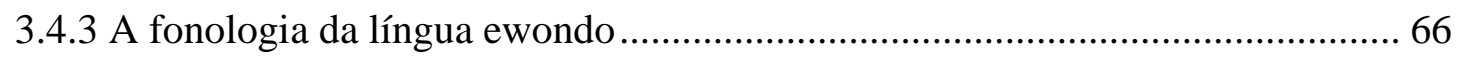

3.5 Características segmentais e autossegmentais das línguas nigero-congolesas ..... 67

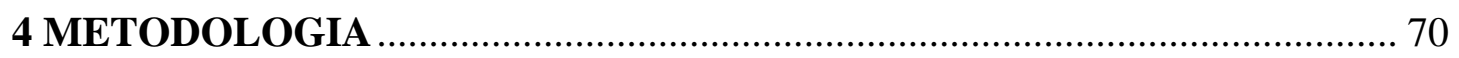

$4.1 \mathrm{O}$ contexto e os participantes da pesquisa............................................................ 70

4.2 Os procedimentos da coleta de dados ............................................................... 73

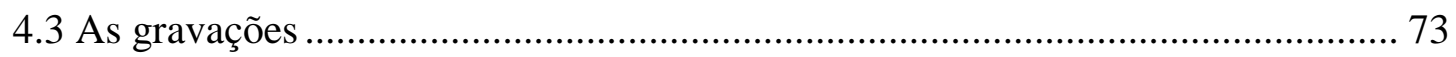

4.4 Procedimentos de análise de dados.................................................................... 74

4.4.1 A segmentação das unidades VV e o cálculo de $z$-score ..................................... 74

4.4.2 Os testes estatísticos usados para a validação dos dados ...................................... 76

4.4.3 A variação da frequência fundamental ........................................................... 78

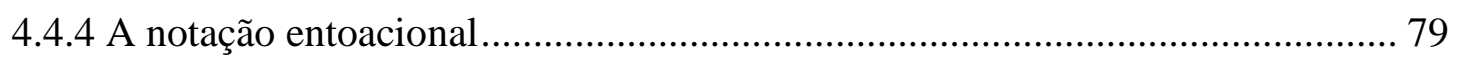

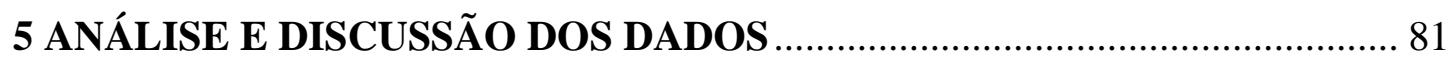

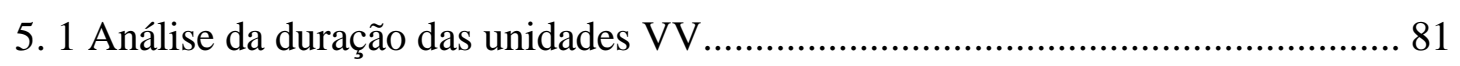

5.1.1 Considerações acerca da discrepância da duração das unidades VV ................ 99

5.2 A análise da variação da frequência fundamental (f0) e a adoção do sistema DaTo para

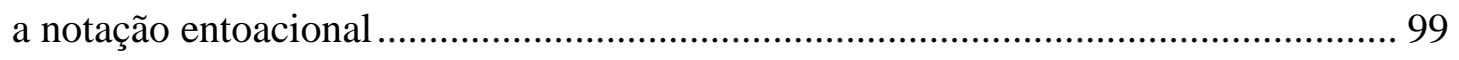

5.2.1 A variação da frequência fundamental ......................................................... 100

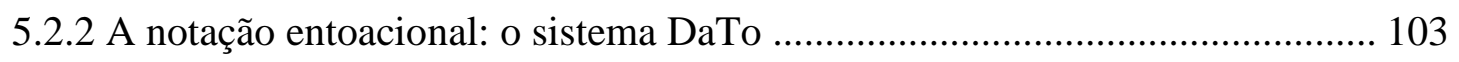

5.2.3 A frequência dos rótulos do sistema DaTo por modalidade de enunciados .... 108

6 CONCLUSÃO

6.1 As respostas aos questionamentos motivadores ao tema ..................................... 114

6.2 Perspectivas para futuras pesquisas embasadas na aquisição do ritmo e aplicabilidade da

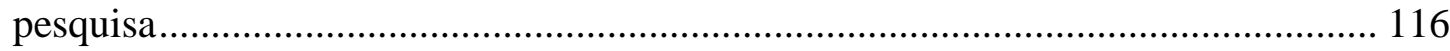

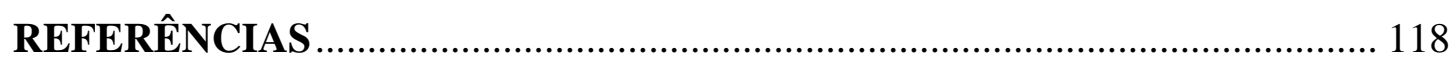


ANEXO A

130

ANEXO B

132

APÊNDICE A

143

APÊNDICE B

146

APÊNDICE C 148 


\section{LISTA DE FIGURAS}

Figura 1: Esquema da comunicação humana sob a perspectiva de Quilis (1988) 41

Figura 2: Comprimento e amplitude de onda 42

Figura 3: Divisão das zonas bantu por Bastin (1978)

Figura 4: As famílias linguísticas africanas pela proposta inicial de Greenberg (1955). 61

Figura 5: Recorte do campo de avaliação Pronúncia, da ficha do avaliador oral do exame Celpe-Bras $\left(2^{\circ} / 2012\right)$

Figura 6: Exemplo de segmentação de enunciado em unidades VV no enunciado "Ela não me respeita", produzido por $\mathrm{C} 1$

Figura 7: Valores de z-score e z-score suavizado de $\mathrm{C} 0$ e $\mathrm{C} 2$ no enunciado "Ela não me respeita" 78

Figura 8: Exemplo de configuração dos rótulos com a notação DaTo (produção de C2) .......80

Figura 9: Gráficos box-plot para constatação do contraste entre $\mathrm{C} 0$ e os colaboradores francófonos para as variáves duração, z-score e z-score suavizado.

Figura 10: Gráficos box-plot para a constatação do contraste entre $\mathrm{C} 0$ e os colaboradores francófonos com representação individual para as variáves duração, z-score e $z$-score suavizado.

Figura 11: Comparativo entre os valores médios de z-score e z-score suavizado, no enunciado injuntivo "arruma seu quarto", entre C0 e Grupo A.

Figura 12: Comparativo entre os valores médios de z-score e z-score suavizado, no enunciado interrogativo "Será que vai chover?", entre C0 e Grupo A

Figura 13: Comparativo entre os valores médios de z-score e $z$-score suavizado, no enunciado declarativo "Ela não me respeita", entre C0 e Grupo A.

Figura 14: Comparativo entre os valores médios de $z$-score e $z$-score suavizado, no enunciado injuntivo "Arruma seu quarto, menina", entre C0 e Grupo B

Figura 15: Comparativo entre os valores médios de $z$-score e z-score suavizado, no enunciado interrogativo "Você já organizou seu quarto hoje?", entre C0 e Grupo B.

Figura 16: Comparativo entre os valores médios de z-score e z-score suavizado, no enunciado declarativo "Eles estavam em casa esperando a mãe chegar com as roupas molhadas", entre C0 e Grupo B. 
Figura 17: Comparativo entre os valores médios de $z$-score e z-score suavizado, no enunciado injuntivo "Arruma seu quarto, menina", entre C0 e Grupo C.

Figura 18: Comparativo entre os valores médios de z-score e z-score suavizado, no enunciado interrogativo "Arruma seu quarto, menina", entre C0 e Grupo C.

Figura 19: Comparativo entre os valores médios de $z$-score e $z$-score suavizado, no enunciado declarativo "Eu já tinha pedido pra ela colocar as coisas no lugar, mas não adianta, ela não me obedece", entre C0 e Grupo C

Figura 20: Gráficos box-plot para constatação do contraste dos valores de f0 entre os colaboradores por L1.

Figura 21: O contorno dinâmico LH no enunciado injuntivo "Arruma seu quarto, menina", produzido por $\mathrm{C} 2$.

Figura 22: O contorno dinâmico >LH no enunciado interrogativo "será que vai chover?", produzido por $\mathrm{C} 1$

Figura 23: O contorno dinâmico vLH em um trecho do enunciado interrogativo "eu já tinha pedido pra ela colocar as coisas no lugar, mas ela não me obedece", produzido por C3. 106

Figura 24: O contorno dinâmico HL no enunciado declarativo "ela não me respeita", produzido por C6.

Figura 25: O contorno dinâmico $>\mathrm{HL}$ em um trecho do enunciado injuntivo "Arruma seu quarto, menina", produzido por $\mathrm{C} 1$.

Figura 26: Comparativo entre as variações da frequência fundamental (f0) dos colaboradores no enunciado declarativo "Ela não me respeita".

Figura 27: Comparativo entre as variações da frequência fundamental (f0) dos colaboradores no enunciado declarativo "Eu já tinha pedido pra ela colocar as coisas no lugar, mas não adianta, ela não me obedece".

Figura 28: Comparativo entre as variações da frequência fundamental (f0) dos colaboradores no enunciado interrogativo "Será que vai chover?".

Figura 29: Comparativo entre as variações da frequência fundamental (f0) dos colaboradores no enunciado interrogativo "Você já organizou seu quarto hoje?".

Figura 30: Comparativo entre as variações da frequência fundamental (f0) dos colaboradores no enunciado injuntivo "Arruma seu quarto, menina". 


\section{LISTA DE QUADROS}

Quadro 1: Examples of complex systems in applied linguistics (Larsen-Freeman e Cameron, 2008, p. 37).... 33

Quadro 2: Quadro consonantal do lingala por Guthrie (1970) 63

Quadro 3: Quadro consonantal do Fon de acordo com Guillet (1972). 65

Quadro 4: Quadro consonantal da Língua Ewondo segundo Redden (1979)..... 66

Quadro 5: Perfil dos colaboradores da pesquisa 72

Quadro 6: Colaboradores agrupados por tempo de imersão 72 


\section{LISTA DE TABELAS}

Tabela 1: Valores de duração, z-score, z-score suavizado e fronteiras para cada unidade VV do enunciado “Arruma seu quarto, menina”, produzido por $\mathrm{C} 0$............................................. 76

Tabela 2: Tabela-padrão para a aplicação do teste ANOVA (Analysis of Variance) ..............77

Tabela 3: Variação de f0 range no enunciado "Será que vai chover?", produzido por C0..... 79

Tabela 4: Valores de duração, z-score, z-score suavizado e fronteiras para cada unidade VV do enunciado "Será que vai chover?", produzido por C0.

Tabela 5: Comparação entre duração (ms), z-score e z-score suavizado entre colaboradores francófonos e controle

Tabela 6: $\mathrm{P}$-valores entre colaboradores $(\mathrm{C} 1$ a $\mathrm{C} 6)$ contrastados com $\mathrm{C} 0$

Tabela 7: Comparação entre duração, z-score e z-score suavizado por L1 faladas pelos colaboradores.

Tabela 8: P-valores obtidos pela comparação de variáveis da Tabela 7, que compara as línguas maternas de todos os colaboradores.

Tabela 9: comparação entre duração, z-score e z-score suavizado pelo tempo de imersão dos colaboradores francófonos e do controle.

Tabela 10: P-valores obtidos pela comparação das variáveis da Tabela 9, que contrasta os valores da duração, do z-score e do z-score suavizado por tempo de imersão dos colaboradores francófonos e controle.

Tabela 11: Comparação de enunciados por modalidades sob as variáveis duração, $z$-score e $z$ score suavizado.

Tabela 12: P-valores obtidos pela comparação das variáveis da Tabela 11, que contrasta os valores da duração, do z-score e do z-score suavizado dos enunciados por modalidade.

Tabela 13: Comparação dos valores de f0 para as produções dos colaboradores francófonos e controle (mín., máx. e range)

Tabela 14: p-valores obtidos pela análise da Tabela 13, que evidencia os valores de f0 (min, máx., e range).....

Tabela 15: comparação dos valores de f0 (min, máx., e range) para as produções dos colaboradores francófonos e controle agrupados por L1

Tabela 16: $\mathrm{P}$-valores obtidos pela análise da Tabela 15 , que evidencia os valores de f0 (min, máx., e range) para as produções dos colaboradores francófonos e controle agrupados por L1. 


\section{LISTA DE SÍMBOLOS E SIGLAS}

[a] vogal baixa central não arredondada

[a] vogal baixa central não arredondada desvozeada

[॰] vogal média-baixa posterior arredondada

[d] consoante oclusiva alveolar sonora

[e:] vogal média-alta anterior não arredondada alongada

[e] vogal média-alta anterior não arredondada

$[\varepsilon]$ vogal média-baixa anterior não arredondada

[ə] vogal média-baixa central não arredondada

[I:] vogal alta anterior não arredondada frouxa alongada

[i] vogal alta anterior não arredondada

[i] vogal alta anterior não arredondada alongada

[u] vogal alta posterior não arredondada

[ø] vogal média-alta anterior arredondada

[s] consoante fricativa alveolar surda

[S] consoante fricativa alveopalatal surda

[t] consoante oclusiva alveolar surda

[u] vogal alta posterior arredondada

$[\mho]$ vogal alta posterior arredondada frouxa

[y] vogal alta anterior arredondada

[z] consoante fricativa alveolar sonora

[3] consoante fricativa alveopalatal sonora

AIF: Organisation Internationale de La Francophonie

ATR: Advanced Tongue Root (raiz da lingual avançada)

Celpe-Bras: Certificado de Proficiência em Língua Portuguesa para Estrangeiros

CPLP: Comunidade dos Países de Língua Portuguesa

CV: Coeficiente de variação

DaTo: Dynamic Tones of Brazilian Portuguese

DCE: Divisão de Temas Educacionais

F0: Frequência fundamental

IC: Intervalo de confiança

IES: Instituição de Ensino Superior 
INEP: Instituto Nacional de Estudos e Pesquisas Educacionais Anísio Teixeira IPA: International Phonetic Alphabet (Alfabeto Fonético Internacional)

L1: Primeira Língua

L2: Segunda Língua

LM: Língua materna

MEC: Ministério da Educação

MRE: Ministério das Relações Exteriores

PALOP: Países Africanos de Língua Oficial Portuguesa

PB: Português Brasileiro

PBSL: Português Brasileiro como Segunda Língua

PEC: Programa Estudantes Convênio

PEC-G: Programa de Estudante-Convênio de Graduação

SLM: Speech Learning Model

MA: Métrica autossegmental

TCLE: Termo de Consentimento Livre e Esclarecido

VV: Vogal a vogal 


\section{O INTRODUÇÃO}

\subsection{O ensino de Português como segunda Língua em Brasília}

O Português Brasileiro (PB) tem ganhado, a cada dia, visibilidade no cenário internacional. Com o objetivo de oferecer oportunidades a estudantes de países também em desenvolvimento, o Ministério das Relações Exteriores (MRE), em sua Divisão de Temas Educacionais (DCE), criou em 1965 o Programa de Estudantes-Convênio de Graduação (PEC-G). O programa tem parceria com diversas Instituições de Ensino Superior (IES) brasileiras e africanas, estabelece relações com a África do Sul, Angola, a Argélia, o Benin, Cabo Verde, Camarões, a Costa do Marfim, o Egito, o Gabão, Gana, Mali, Marrocos, a Namíbia, a Nigéria, o Quênia, a República Democrática do Congo, o Congo, São Tomé e Príncipe, o Senegal, a Tanzânia, o Togo e a Tunísia. É importante ressaltar que o PEC-G também mantém convênios com países da América Latina e da Ásia.

Em uma breve comparação de dados, a DCE divulgou em 2013 que, desde o ano 2000 até 2013, o Brasil recebeu 6001 estudantes africanos, 1636 de países da América Latina e 30 da Ásia. A maioria desses estudantes vem de Países Africanos de Língua Oficial Portuguesa (Palop) e não é um requisito, para esses, aprender o PB para ingressar nas IES. Dos dados provenientes da DCE, 84,6\% dos estudantes são de Palop. Outros 9,4\% têm o francês como língua de alfabetização e 5,8\%, o inglês. Para que haja o ingresso nas IES aos francófonos, é necessário que o candidato obtenha, no mínimo, certificação intermediária no Certificado de Proficiência em Língua Portuguesa para Estrangeiros (Celpe-Bras). Para isso, os estudantes participam um curso de Português do Brasil como Segunda Língua (PBSL), muitas vezes, em IES diferentes daquelas para onde irão após a aprovação.

A Universidade de Brasília recebeu, nos anos de 2011, 2012 e 2013, uma média de 14 estudantes por ano, todos de países africanos francófonos. Após sete meses de imersão no $\mathrm{PB}$, com contatos formal e informal, os estudantes foram submetidos ao Celpe-Bras. A pesquisadora deste trabalho atuou como docente desses estudantes nos programas de 2011, 2012 e parte de 2013, quando pôde perceber as particularidades em suas produções linguísticas, as quais poderiam acarretar dificuldades na aprendizagem do PB.

A proposta deste trabalho é a análise das interferências fonológicas das línguas maternas desses estudantes no PB. A revisão bibliográfica elaborada para esta pesquisa 
levantou a existência de pesquisas anteriores feitas, especificamente, sobre o século XIX, em que se abordavam aspectos morfossintáticos da aquisição/aprendizagem do português por africanos. Entretanto, não foram encontrados estudos que vislumbrassem aspectos fonológicos desse processo: aquisição do português brasileiro por africanos francófonos. No contato em sala de aula, foi perceptível que os sujeitos de pesquisa possuem uma aquisição rítmica diferenciada de outros francófonos.

Esta pesquisa faz parte de um projeto maior intitulado Aquisição do português como primeira e segunda língua, sob coordenação da Professora Dra. Daniele Marcelle Grannier, que tem por objetivo estudar o processo de aquisição do português como primeira e segunda língua, bem como identificar a estrutura da língua portuguesa e suas contribuições para estrangeiros, surdos e indígenas.

\subsection{O mapeamento da Unesco sobre a francofonia}

Para conhecer a fundo as interferências fonológicas das línguas maternas dos sujeitos de pesquisa, é preciso identificar o mosaico da realidade linguística africana. Sobre esse tema, é necessário saber que, na África, há aproximadamente 2035 línguas que se subdividem em quatro grandes famílias. Esses são recentes dados de 2010, divulgados pela Organização das Nações Unidas para a Educação, a Ciência e a Cultura (Unesco): a nigero-congolesa (aproximadamente 1436 línguas, incluindo a subfamília bantu), o afroasiático (com 371 línguas), a nilo-saariano (com 196 línguas) e a khoisan (com 35 línguas). Na Nigéria, são faladas 410 línguas, na República Democrática do Congo, 206, na Etiópia, 97, em Camarões, 185 línguas, no Benim, 58 línguas, no Congo, 31, na Tanzânia, 120, e em Mali, 12.

No que concerne à aquisição do PB por africanos francófonos, estudos anteriores evidenciam que, entre o século XVII e o século XIX, africanos e afrodescendentes correspondiam a cerca de $60 \%$ da população brasileira (MUSSA, 1991). É sabido também que, passados mais de 500 anos de muitas histórias de contato linguístico, hoje não há língua africana falada como nativa em nenhuma comunidade linguística brasileira. Sobre a formação do português brasileiro, Mattos e Silva (1993) afirma:

A partir da segunda metade do século XVIII, uma série de fatores de história externa conduz à definição do Brasil como país majoritariamente de língua nem indígena nem africana. O multilingüismo menos ou mais generalizado, 
a depender da conjuntura histórica local nos séculos anteriores, localiza-se e abre, então, o seu caminho o português brasileiro. (MATTOS E SILVA, 1993, p. 83)

Seria enriquecedor para a pesquisa linguística que o contato das línguas africanas com o português recortado neste trabalho fosse também contrastado com acervos escritos do português falado por africanos no século XIX. Entretanto, a documentação do contato dos séculos iniciais é pouco conhecida e inconsistente, talvez pelo fato de os afrodescendentes não terem sido escolarizados durante a escravidão. Mattoso (1990) aponta que a ausência de documentos escritos por negros é observada tanto por linguistas quanto por historiadores.

Os africanos estão imersos em um contexto multilíngue, o que requer, por parte das organizações educacionais, uma melhor eficácia nas políticas linguísticas em todos os estados. De acordo com a Unesco (2010), durante o ensino primário na África, o ensino das línguas nacionais tem o objetivo de favorecer a aprendizagem e a aquisição progressiva de uma língua de comunicação internacional: o francês. Dessa forma, a primeira língua do indivíduo exerce uma influência determinante sobre seu nível cognitivo e afetivo, afetando o curso natural do bilinguismo ou do plurilinguismo escolar. A Unesco (2010) aponta que há países, como o Benim, Burkina Faso, o Burundi, Camarões, a Nigéria e o Senegal, em que as situações sociolinguísticas são muito diversificadas e representam estados de utilização das línguas nacionais muito diferentes nos sistemas educativos.

A Unesco (2010) alerta para a necessidade do ensino das línguas africanas na escola não apenas como uma atitude nacionalista, mas também para uma compreensão da identidade nacional e do processo de colonização dos países. Além disso, a proposta é que os indivíduos conheçam seus valores culturais e participem ativamente da construção de seu patrimônio. Dados obtidos na Nigéria, onde já há ênfase no ensino das línguas nacionais, evidenciam uma melhora no rendimento escolar dos alunos e um posicionamento melhor desses sujeitos no campo socioeconômico.

\subsection{As situações de contato e a interferência linguística}

Sabe-se que no território africano há várias ocorrências de contato entre línguas de diferentes famílias. Pode-se intitulá-las línguas de contato, pois são usadas alternadamente 
pelas mesmas pessoas. As situações de contato podem ser percebidas pelo aumento de empréstimos, alterações fonológicas, gramaticais, misturas de línguas.

A interferência está no desvio da norma das duas línguas e ela implica um rearranjo de padrões. O contato de línguas, para alguns antropólogos, é dado como um dos aspectos do contato de culturas, como uma faceta da difusão cultural e da aculturação. Dessa forma, é de extrema importância contextualizar o contato com critérios extralinguísticos: sócio-históricos, políticos, econômicos e educacionais.

Para Weinreich ${ }^{1}$ (1953), quanto maior a diferença entre os dois sistemas, maior é a dificuldade de sua aprendizagem e a área potencial de interferência. O ponto de interesse deste trabalho é observar as interferências de formas fonológicas no português. O que não impede que sejam também futuramente identificadas na sintaxe, na semântica e nas relações gramaticais.

O contato linguístico é tratado aqui abordando línguas, dialetos e variedades do mesmo dialeto da mesma forma, não importando o status dado ao sistema linguístico, a interferência será a mesma. Outros fatores também devem ser considerados na situação de contato dos sujeitos desta pesquisa: a facilidade de expressão verbal e a habilidade de manter as duas línguas separadas, a proficiência nas duas línguas, a competência linguística, a maneira de aprender outra língua e também as atitudes com relação a cada língua, como os estereótipos.

Os dados desta pesquisa foram analisados no programa PRAAT (BOERSMA, P. A.; WEENINK, D). O programa foi desenvolvido pelos linguistas Paul Boersma e David Weenink, do Instituto de Ciências Fonéticas da Universidade de Amsterdã, e tem como principal foco a análise acústica, oferecendo diversas possibilidades de uso, como: análise espectrográfica, síntese de fala, experimentos de percepção auditiva e a criação de gráficos.

A análise de dados evidenciou que a estrutura rítmica das produções dos sujeitos, africanos francófonos, é amplamente distinta da estrutura do PB. Para chegar a essa conclusão, foi necessária uma revisão bibliográfica de estudos que descrevessem a estrutura rítmica do português e também das línguas maternas desses aprendizes. Há trabalhos como Acento e Ritmo, de Massini-Cagliari, Elementos de Fonética do Português, de Luiz Carlos Cagliari e Incursões em torno do ritmo da fala, de Plínio Barbosa, que contemplam descrições

\footnotetext{
${ }^{1}[\ldots]$ every enrichment or impoverishment of a system involves necessarily the reorganization of the old distinctive oppositions of the system. To admit that a given element is simply added to the system which receives it without consequences for this system would ruin the very concept of system.
} 
do ritmo do português brasileiro. Sobre o ritmo, é necessário saber que é próprio da organização temporal da linguagem e, para Massini-Cagliari (1992, p. 33), o ritmo na Linguística se preocupa com a "noção de expectativa de uma eventual repetição de algum parâmetro no tempo". O ritmo é um aspecto prosódico da língua, embora saibamos que existam outros, como a entoação, a acentuação, o tom, o volume e a qualidade de voz.

São de interesse desta pesquisa: a análise do padrão rítmico do português falado por africanos francófonos, a interferência de ritmo das línguas da família nigero-congolesa na escolarização desses sujeitos em língua francesa e a interferência indireta no Português Brasileiro.

\subsection{O exame Celpe-Bras}

O retorno para os sujeitos de pesquisa, que integram o grupo de colaboradores, é auxiliá-los no exame Celpe-Bras, exigência para sua permanência no Brasil e para o ingresso no curso superior. O exame Celpe-Bras é elaborado atualmente pelo Instituto Nacional de Educação e Pesquisa (INEP) em parceria com o Ministério da Educação (MEC) e o Ministério das Relações Exteriores (MRE). Dividido em duas etapas: oral e escrita, o exame consiste na avaliação das habilidades de ouvir, falar, ler e escrever. A etapa escrita tem duração de três horas e conta com a exibição de um vídeo, a reprodução de um áudio e a exposição de dois gêneros textuais. A partir dessas fontes de insumo, o examinando deve produzir quatro textos escritos adequados ao gênero solicitado. A etapa oral consiste em uma entrevista de, em média, 25 minutos. No momento da entrevista, o examinando é avaliado pelo entrevistador e pelo observador que, separada e sigilosamente, avaliam a fluência, a entonação, o ritmo, a pronúncia, as adequações léxicas e gramaticais e a interação com notas de 1 a 5 .

São certificados os examinandos que obtêm os níveis intermediário, intermediário superior, avançado e avançado superior. Observa-se que, para o ingresso em programas de intercâmbio como o PEC-G, o nível exigido é, no mínimo, o intermediário. Após a obtenção da certificação, os estudantes têm matrícula regular em IES, que são escolhidas previamente pelos próprios estudantes em seus países de origem, juntamente à opção de bacharelado ou licenciatura. 


\subsection{Objetivos, pergunta de pesquisa e hipóteses}

O objetivo principal desta pesquisa é descrever os aspectos prosódicos relacionados à aquisição do PB por africanos francófonos. Para isso, inicialmente, relatar-se-á o mosaico das línguas africanas sob a interferência de outras línguas, como o francês. Por meio da discussão teórica, a competência multilingual dos africanos será abordada e, em especial, serão mostrados dados das línguas maternas dos colaboradores desta pesquisa. Dentre esses dados, estão descrições de cunho segmental e suprassegmental.

São também objetivos desta tese: descrever as curvas entoacionais dos colaboradores, falantes de línguas da família nigero-congolesa, em comparação àquelas do falante nativo do PB e contrastar o pitch range dos picos da curva entoacional, considerando o tempo de imersão, a língua materna e a modalidade dos enunciados. Pela análise dos dados, espera-se que sejam criadas bases para futuras aplicações didáticas.

Para nortear este estudo e alcançar seus objetivos, uma pergunta de pesquisa é de grande relevância:

1. Que aspectos prosódicos caracterizam a produção dos africanos francófonos aprendizes do PB?

Dessa forma, são feitas também perguntas secundárias e consoantes com os objetivos de pesquisa:

a) Há diferenças na duração das unidades VV entre os colaboradores francófonos e o controle? Como se dá o efeito da duração dessas unidades na prosódia?

b) Quais são os contrastes entre os valores de z-score suavizado entre os colaboradores francófonos e o controle?

c) Quais são as diferenças entre os picos máximos e mínimos, medidos em Hz, entre os colaboradores francófonos e o controle? Há diferenças significativas de f0 range?

d) De acordo com a análise da curva entoacional, qual é a frequência dos rótulos do sistema DaTo nos enunciados dos colaboradores francófonos em comparação àqueles produzidos pelo colaborador controle?

A hipótese central desta tese é que a percepção da fala com ritmo destoante do PB, produzida pelos africanos francófonos, seja resultado da influência de suas línguas maternas, da família nigero-congolesa. Outra hipótese é que grupos com maior tempo de imersão tenham interferênciasprosódicas da L1 menores que aqueles com menor tempo de contato 
com o PB. Essas interferências envolvem a duração das unidades VV em enunciados declarativos, injuntivos e interrogativos, a equivalência ou aproximação dos rótulos do sistema DaTo nesses enunciados e a variações de pitch.

\subsection{A organização da Tese}

Esta tese está organizada em seis capítulos: o primeiro sobre as teorias de aquisição de segunda língua, o segundo sobre a importância da fonética acústica para os estudos linguísticos, o terceiro apresenta um panorama das línguas africanas, o quarto, a metodologia utilizada na pesquisa, o quinto, a análise dos dados coletados com os colaboradores e, por fim, o sexto, a conclusão. Todos os capítulos apresentam uma introdução às discussões apresentadas. Nos anexos, está o Parecer do Comitê de Ética, o Termo de Consentimento Livre e Esclarecido, a ficha de identificação do colaborador, o script do SG Detector e o material usado como insumo para a coleta dos dados. 


\section{AQUISIÇÃO DE SEGUNDA LÍNGUA}

Neste capítulo, discutir-se-á sobre as teorias de aquisição da linguagem, especificamente de segunda língua. Há o percurso dos estudos linguísticos voltados à aquisição linguística para a adoção de um posicionamento teórico referente às interferências da L1 na L2.

\subsection{A adoção da terminologia Segunda Língua}

Neste trabalho, a primeira língua (L1) será tratada como sinônimo de língua materna (LM). Quando o sujeito adquire ou aprende uma segunda língua, o desenvolvimento se dá por meio de seu conhecimento de mundo aliado à competência linguística. É através da L1 que são adquiridos valores pessoais e sociais. Ao se referir à língua materna dos sujeitos desta pesquisa, menciona-se aquela língua usada, na maioria das vezes, no dia a dia desses colaboradores. A língua materna não será tratada aqui como a língua da mãe ou como a primeira língua aprendida em contextos formais.

Nesta pesquisa, o contato com o PB será intitulado de aquisição, uma vez que se refere também ao contato informal e natural por meio de situações reais, já que os sujeitos estão em contexto de imersão com o PB. Observa-se que os colaboradores também passaram por situações de ensino formal, dessa forma, o termo aquisição abrange os dois contextos. Como o contato linguístico dos sujeitos desta pesquisa se deu em contexto de imersão, tratarse-á o fenômeno como aquisição de segunda língua e não de língua estrangeira.

\subsection{Weinreich e a teoria do contato de línguas}

O processo de aquisição de segunda língua foi amplamente discutido na década de 1970. Entretanto, há relatos anteriores de estudos linguísticos, como o livro Languages in Contact, de Uriel Weinreich (1953). Nessa obra, o autor discute como dois sistemas linguísticos se relacionam entre si na mente de um mesmo indivíduo. Um conceito de suma 
importância para Weinreich (1953) é o de interferência, que, para o autor, se baseia nas instâncias de desvios de normas ou o modo que a linguagem ocorre no discurso de sujeitos bilíngues, como resultado da familiarização com mais de uma língua.

A interferência pode acontecer em todos os sistemas linguísticos. Os falantes podem transferir a fonologia da L1 ignorando distinções feitas na segunda língua (L2), mas não na L1. No nível gramatical, os falantes constroem enunciados inadequados na L2 devido à estrutura da L1.

Para Weinreich (1953), a interferência não acontece somente no sentido L1 para L2, mas há também efeitos no sentido contrário, L2 para L1, havendo, inclusive, uma perda linguística gradual em alguns bilíngues. Para o autor, a interferência pode acontecer em duas dimensões: no uso linguístico atual de um bilíngue e em seu conhecimento linguístico². Embora o principal objetivo do livro Languages in Contact fosse tratar do conhecimento linguístico ao invés de seu desenvolvimento, pode-se dizer que as questões sobre o conhecimento linguístico e sua aquisição, bem como o papel da interferência são temas que levantaram grandes discussões acerca dos trabalhos de Weinreich.

Weinreich (1953) trouxe, com sua produção científica, uma grande influência para o estudo da aquisição de segunda língua. Um dos aspectos mais importantes por ele levantado é a concepção da organização do significante e do significado na mente de indivíduos bilíngues. Observando exemplos de relações de palavras da língua inglesa, Weinreich (1953) exemplifica com a palavra book, de equivalência em russo, kniga. Uma possibilidade para os bilíngues é separar dois conceitos na mente, correspondendo a duas palavras separadas. Os indivíduos sabem o que significa book e o que significa kniga, mas não há uma ligação entre as duas línguas na mente, os dois sistemas linguísticos coexistem. Weinreich (1953) usa o termo bilinguismo coordenado para esses casos. É necessário saber que outros autores também já haviam mencionado, em período similar, o conceito de bilinguismo coordenado, como se vê em Ervin e Osgood (1954).

Além desse tipo de bilinguismo, há outra possibilidade em que os bilíngues teriam, por exemplo, um significado para book ligado a duas palavras diferentes, ou significantes /kniga/ ou /buk/ nas duas línguas. Esse tipo de bilinguismo é considerado por Weinreich como composto, descrito tal qual aquele em que duas línguas são ligadas na mente no nível conceitual. Uma terceira visão de análise do bilinguismo é quando a segunda língua não é

\footnotetext{
2 "In speech, interference is like sand carried by a stream; in language, it is sedimented sand deposited on the bottom of a lake" (Weinreich, 1953, p. 1)
} 
adquirida diretamente, mas por meio da L1. Por exemplo, um falante de inglês, em situação de aquisição do russo, conectaria a palavra russa /kniga/ diretamente à palavra inglesa /buk/ ao invés de fazer uma conexão ao significado do signo linguístico. Nesse tipo de bilinguismo, a segunda língua é derivada da primeira, ao invés de ter uma existência separada. Intitulado de bilinguismo subordinado por Weinreich (1953), esse modelo foi fundido como bilinguismo coordenado na teoria de outros estudiosos posteriormente.

Alguns estudos procuraram evidenciar as diferenças entre o bilinguismo composto e o coordenado, como Jakobovits e Lambert (1961). Por exemplo, a repetição contínua da palavra em uma língua causaria a perda de características conotativas e emocionais nas duas línguas nos casos de bilinguismo composto, e apenas em uma língua nos falantes que passarem por uma aquisição de bilinguismo coordenado. Experimentos mostraram que a distinção não pode ser claramente aplicada sempre (OLTON, 1960).

A distinção entre bilinguismo composto e coordenado foi foco de discussões e até negada por muitos estudiosos. McLaughlin (1978) afirma que a distinção não foi validada experimentalmente e, por isso, há dificuldades em colocá-la em prática. Ainda assim, o tema foi foco de investigação por muitos anos e recebeu revisões de vários pesquisadores. Sob a perspectiva linguística, as falhas da área de aquisição de segunda língua estão na restrição do escopo do vocabulário, ao invés de se considerar o sentido conotativo e os diversos aspectos do conhecimento linguísticos apontados por Weinreich (1953). Isso também pode ser observado na conexão entre o significante e o significado, agora visto de maneira mais complexa que a relação linear proposta nos diagramas de Weinreich (1953).

Para Weinreich (1953), o bilinguismo é a prática alternada de duas línguas, um conceito direto e prático, tratando-se da terminologia linguística. Entretanto, o termo bilinguismo pode agregar várias definições. Outra definição considerada extrema por Cook (1993) é a de Bloomfield (1933), que afirma que o bilinguismo é como um controle de um nativo em duas línguas. Também chamado de ambilinguismo por Halliday, MacIntosh e Strevens (1994). Haugen (1953) considera que bilinguismo é qualquer uso de uma L2.

Observa-se que os colaboradores desta pesquisa se enquadram em casos de multilinguismo. Entretanto, são abordadas as discussões acerca do bilinguismo, uma vez que bilíngues e multilíngues podem apresentar níveis diferentes de proficiência das línguas com as quais se comunicam, ainda que multilíngues tenham a habilidade de usar mais que duas línguas. Assim, o desempenho também pode variar nos contextos de uso e, também, com o objetivo da comunicação. 


\subsection{As contribuições acerca da Análise Contrastiva}

Baseada nos estudos de Fries (1945) e Lado (1957), a Análise Contrastiva, em sua Versão Forte, propunha a identificação de semelhanças e de diferenças entre duas línguas por meio de um contraste. Esperava-se, assim, que fosse possível prever os problemas que os aprendizes teriam no processo de aquisição e, consequentemente, que houvesse base para a preparação de materiais didáticos e abordagens específicas para os pares das línguas em jogo.

Alvo de muitas críticas e de novos embates teóricos, como a publicação de Chomsky Aspects of the Theory of Syntax em 1965, a Análise Contrastiva passou por reformulações. Em 1967, Corder propôs uma nova avaliação de erros, incitando bases para a transformação em sua Versão Fraca: a Análise de Erros. Coletados por meio de dados provenientes dos próprios aprendizes, na Versão Fraca, o professor usava dados oriundos de gravações, por exemplo, através dos quais poderia analisar, listar os erros e classificá-los de acordo com sua frequência, causa, tipologia, entre outros aspectos. A diferença entre as duas versões está na concepção de aquisição da linguagem e, especialmente, nas discussões que giram em torno da estrutura linguística.

A partir da década de 1970, muitos estudos foram feitos no campo de aquisição de segunda língua. Os trabalhos de Selinker (1972), dentre os de maior relevância, estabeleceu inicialmente os estudos sobre interlíngua. Considerando como evidências linguísticas a performance dos aprendizes na L2, Selinker excluía estudos baseados em experimentos e exercícios. Sua metodologia baseava-se no discurso dos aprendizes. Parte de sua teoria advém dos estudos de Corder (1967), o qual sugeria que o aprendizado tanto da L1 quanto da L2 se realizava por meio da aplicação de estratégias de input para a internalização de regras gramaticais.

Corder (1967) trouxe aos estudos de aquisição da linguagem uma discussão a respeito da análise de erros no processo de aquisição da L2. O conceito de erro precisaria ser revisto por meio de uma metodologia complexa e detalhada a partir do discurso dos aprendizes. A proposta da análise de erros baseou-se em três etapas: o reconhecimento da idiossincrasia, em que o pesquisador analisava os enunciados produzidos pelo aprendiz a fim de reconhecer os erros e reconstruir estruturas, ou ainda inferindo as intenções do aprendiz por meio do contexto linguístico; a sistematização do dialeto idiossincrático do aprendiz, em que o pesquisador observa as sentenças de interlíngua produzidas pelos aprendizes e as 
descreve; e a explicação dos desvios na segunda língua, em que o pesquisador buscava explicar o surgimento das inadequações.

O posicionamento do texto de Corder (1967) sobre o valor dos erros especialmente para o pesquisador foi de grande importância no campo da aquisição da segunda língua. Adotando a mesma visão de Chomsky (1957) de que a linguagem é uma atividade criativa, Corder acredita que o aprendiz de segunda língua também reformula hipóteses, embora de maneira diferente.

Com os estudos de Corder, novas discussões surgiram sobre a aquisição de segunda língua. Estudiosos como Nemser (1971) e Selinker (1972) propuseram novas visões para o campo com as discussões sobre sistema aproximado e interlíngua, respectivamente. Para Nemser (1971), o sistema aproximado faz referência a qualquer língua que não seja a não nativa. O autor propõe uma classificação diferenciada: língua objeto (L2), língua origem (L1) e sistema aproximado (o sistema que surge na tentativa de alcançar a L2). Nemser (1971) sugere ainda o estudo da regularidade dos erros de percepção e produção como objeto de pesquisa.

Usado para nomear a língua de falantes não nativos, o termo interlíngua foi trazido por Selinker (1972) para nomear um sistema independente o qual não corresponde nem à língua materna nem à língua-alvo. O objetivo de Selinker foi sistematizar dados importantes para a elaboração de uma teoria psicolinguística de aprendizagem. Consonante à ideia de Chomsky, Selinker propõe uma estrutura latente da linguagem, responsável pela aquisição da segunda língua e pelo processo de aprendizagem de sucesso de alguns adultos. Além disso, Selinker (1972) propõe uma estrutura psicológica latente, que é ativada quando o indivíduo não atinge a proficiência ideal na segunda língua se comparado com um falante nativo. É no sistema psicológico latente que surge a interlíngua, e também as fossilizações de regras gramaticais ou características da L1, as quais são conversadas na língua-alvo.

Observando o percurso da pesquisa sobre aquisição e aprendizagem de línguas, Gass (1988) aponta três fases de desenvolvimento científico: a aceitação da transferência da língua materna como principal fator no processo de aquisição, a negação da interferência da L1 na aquisição da L2 e a releitura das transferências da L1, sendo vistas de maneira relativa e qualitativa.

Com um foco sociolinguístico, Schumann (1976) propôs uma análise de interlíngua de um falante de espanhol em imersão na língua inglesa. Schumann aborda a existência de uma pidgnização no processo de aquisição da L2, já que no início os aprendizes apresentam características semelhantes aos pidgins, como a falta de morfologia flexiva e derivações. 
Schumann (1976) justifica que a pidgnização ocorre pela distância social e psicológica entre o aprendiz e L2.

Aparentemente vistas como uma dicotomia, as Hipóteses Contrastiva e a Criativa receberam outro enfoque a partir da década de 1980. Selinker e Gass (1983) consideraram na introdução de Transfer in Language Learning que a afirmação de que essas hipóteses eram incompatíveis empobreceu as discussões sobre aquisição por uma década. Para eles, conciliar a visão de que a aquisição da L2 é um processo de testagem de hipóteses é plenamente acessível.

A teoria de Chomsky também foi fonte de questionamentos à área da aquisição. Para a aquisição infantil, a proposta de princípios e parâmetros deu muitas respostas. Entretanto, como há muitas diferenças entre o processo de L1 e L2, ainda há dúvidas sobre a aplicabilidade da proposta chomskyana para aquisição de L2, já que os aprendizes podem apresentar fossilizações, insucesso na aprendizagem e influência de fatores afetivos, por exemplo, se comparados às crianças.

\subsection{Linguagem e aprendizagem: as discussões atuais acerca da teoria dos sistemas complexos e do emergentismo}

Com seu início na década de 80, a teoria dos sistemas complexos consiste em uma abordagem multidisciplinar aplicada a várias ciências. No que tange aos estudos da linguagem, é na linguística aplicada que essa teoria tem tomado grandes dimensões. A teoria de sistemas complexos tem várias origens e foi denominada anteriormente como teoria da complexidade, tratando de sistemas complexos, dinâmicos, não lineares, auto-organizados, abertos, emergentes, caóticos e adaptativos (LARSEN-FREEMAN, 1997). Nas últimas duas décadas, a teoria da complexidade foi levada também a outras áreas, além daquelas em que se originou: biologia, matemática e física. A proposta era adotar as ideias da teoria para entender outros sistemas complexos que passavam por processos dinâmicos. Já mais próximos da linguística, psicólogos observaram a potencialidade da aplicação da teoria de sistemas dinâmicos ao desenvolvimento motor e até mesmo a outros sistemas humanos, criando um campo propício para outras aéreas da psicologia. Em 1994, Thelen e Smith afirmaram que a abordagem de sistemas dinâmicos proporcionaria uma base biológica, cultural e contextual à cognição humana. 
Em 1997, Larsen-Freeman escreveu explicitamente sobre a importância de se observar o processo de aquisição de segunda língua pela teoria do caos, ou complexidade. Logo após, em 2002, discutiu sobre como a teoria poderia ajudar na superação do dualismo que afeta o campo da linguística aplicada. As discussões foram frutíferas e hoje há estudiosos como De Bot, Lowie e Verspoor, os quais discutem sobre a aplicação da teoria de sistemas dinâmicos à aquisição de segunda língua; Herdina e Jessner, que abordam as mudanças na proficiência multilinguística em níveis individuais; e Lee e Schumann (2003), que usam a visão da teoria para observar a evolução da linguagem, dentre outros.

Larsen-Freeman e Cameron (2008) afirmam que a influência da teoria de sistemas dinâmicos tem chegado aos linguistas aplicados, fazendo-os refletir, cada vez mais, como as considerações e perspectivas de seu campo podem ser desafiados pela complexidade. A linguagem usada como discurso de uma comunidade pode ser descrita tal qual um sistema, igualmente assim as interações entre professores e estudantes na sala de aula ou até mesmo o funcionamento da mente humana. As autoras esperam que, reformulando conceitos para essas situações e fenômenos, seja possível caminhar em direção a novas ações e esclarecimentos no campo da Linguística Aplicada.

\subsubsection{A natureza dos sistemas complexos e dinâmicos}

Os sistemas complexos são aqueles que estão em constante processo de mudança sem interrupção de seu fluxo. Neles está o atrativo para os linguistas, juntamente às suas similaridades aos sistemas, como: línguas, discurso, salas de aulas, aprendizes em sala de aula como grupo dinâmico. Há teorias que desconsideram ou removem a dinamicidade dos sistemas, observando-os como estáticos para serem objetos de análise. A teoria dos sistemas complexos, ao contrário dessa, propõe métodos de comparação para os sistemas em mudança, observando seus processos com o tempo.

Para entender a teoria, é preciso, primeiramente, entender o que é um sistema. Para Larsen-Freeman e Cameron (2008), um sistema é o produto de um conjunto de componentes que interagem de maneiras particulares para produzirem algo de estado mais total ou, até mesmo, uma forma em um ponto específico no tempo. Naqueles intitulados sistemas simples, um conjunto pequeno de componentes similares é ligado de maneira previsível e imutável, já nos sistemas complexos, ou dinâmicos, há elementos que têm sequencialidade, entretanto, 
seus estados futuros dependem de seu estado no presente. Nesses sistemas, tudo é dinâmico, não apenas os elementos, mas os agentes que o mudam com o tempo. Além disso, a maneira como os agentes interagem também acarreta mudanças, pois eles emergem em algum momento, podem evoluir e ainda acabar quando não houver mais motivos para que existam. O contexto de aquisição de segunda língua só poderia gerar um sistema aberto, sensível ao meio, como acontece, por exemplo, com um aprendiz em sala de aula.

Os sistemas complexos são caracterizados por sua heterogeneidade, dinamicidade, não linearidade, adaptabilidade e abertura. A linguagem é um sistema não linear, por exemplo. Em sistemas não lineares, a interação entre elementos e agentes muda com o tempo. Nos sistemas adaptativos, uma mudança em uma parte do sistema leva a uma alteração no todo. Nesses sistemas, o contexto não é separado, mas parte deles e de sua complexidade.

Sistemas abertos permitem que energia e matéria entrem de fora para dentro deles. A existência dessa abertura pode dar uma característica menos equilibrada ao sistema, embora haja um esforço para que as mudanças se adaptem e, assim, se mantenha a estabilidade.

Em uma analogia à linguística aplicada e à teoria dos sistemas complexos, LarsenFreeman e Cameron (2008, p. 37, Table 2.2 Examples of complex systems in applied linguistics) propõem:

\begin{tabular}{|c|c|c|}
\hline Field & Spoken interaction & $\begin{array}{c}\text { Classroom language } \\
\text { learning }\end{array}$ \\
\hline Agents & $\begin{array}{l}\text { speakers, their language } \\
\text { resources }\end{array}$ & students, teachers, languages \\
\hline Heterogeneity & $\begin{array}{c}\text { speaker backgrounds, styles, } \\
\text { discourse topics }\end{array}$ & $\begin{array}{l}\text { abilities, personalities, } \\
\text { learning demands }\end{array}$ \\
\hline Organization & dyads, speech communities & $\begin{array}{l}\text { class, groups, curricula, } \\
\text { grammars }\end{array}$ \\
\hline Adaptation & shared semantics, pragmatics & $\begin{array}{c}\text { imitation, memorizing, } \\
\text { classroom behaviors }\end{array}$ \\
\hline Dynamics & $\begin{array}{c}\text { conversation dynamics, } \\
\text { negotiation of understanding }\end{array}$ & $\begin{array}{l}\text { classroom discourse, tasks, } \\
\text { participation patterns }\end{array}$ \\
\hline Emergent behavior & $\begin{array}{l}\text { discourse events, idiom, } \\
\text { specific languages e.g. } \\
\text { 'english' }\end{array}$ & $\begin{array}{l}\text { language learning, } \\
\text { class/group behavior, linguae } \\
\text { francae }\end{array}$ \\
\hline
\end{tabular}

Quadro 1: Examples of complex systems in applied linguistics (Larsen-Freeman e Cameron, 2008, p. 37)

Larsen-Freeman e Cameron (2008) apontam que a linguagem deve ser concebida como complexa, adaptativa, como um sistema dinâmico. Por uma perceptiva nativista, as autoras consideram que, como humanos, a herança genética se baseia nos mecanismos gerais 
de cognição e sociabilidade que interagem com o ambiente para organizar o comportamento. Muitas das pesquisas em aquisição de segunda língua trataram o processo como estático e composto por regras gramaticais, sendo esses os únicos objetivos linguísticos.

O processo de aprendizagem não se baseia apenas em levar o aprendiz a focar na forma, mas também em promover a constante adaptação aos usos linguísticos e à construção de significados, proporcionadas em situações dinâmico-comunicativas. Além disso, as diferenças entre aprendizes não devem ser desconsideradas, pois são partes da dinamicidade do comportamento dos indivíduos com diferentes orientações, tais quais as relações com grupos sociais e até mesmo a história pessoal, tendo em vista que os aprendizes são construtores de seu universo linguístico.

Para a implementação de sistemas dinâmicos, De Bot e Makoni (2005) apontam que modelos de redes conexionistas precisam trabalhar melhor. Como resultado da ativação por input e output, as conexões tendem a se tornar mais fortes. Se não fortalecidas regularmente, elas podem se deteriorar. O ponto de partida da Teoria dos Sistemas Dinâmicos é que um sistema em desenvolvimento é mantido por um fluxo de energia. Assim, cada desenvolvimento cognitivo é forçado a recursos limitados, como memória, atenção, motivação, dentre outros. Para De Bot e Makoni (2005), o sistema está em constante interação complexa com seu meio e recursos internos. Sua múltipla interação de componentes produz pontos de equilíbrio auto-organizados cuja forma e equilíbrio dependem das restrições do sistema. O crescimento, então, é visto como um processo repetitivo, o que significa que o nível presente de desenvolvimento depende criticamente do próximo nível (VAN GEERT, 1998).

De Bot e Makoni (2005) afirmam que as línguas evidenciam todas as características de um sistema dinâmico e, assim, podem ser vistas pela perspectiva da teoria. Os sistemas linguísticos possuem muitos subprocessos, como o pragmático, o sintático, o lexical e o fonológico, que, por sua vez, interagem e se auto-organizam, dependendo de recursos internos e externos. Dessa forma, se pode ver o crescimento e declínio, quando ocorrem, embora nunca se instaurem completamente.

Tratando-se do desenvolvimento da linguagem, De Bot e Makoni (2005) apontam que é necessário se fazer uma distinção entre recursos internos e externos. Respectivamente, são desenvolvidos individualmente e envolvem motivação, informações pessoais e tempo, e estão fora do individual, envolvendo os ambientes espaciais em que ocorrem, informações individuais, como a língua usada no ambiente, recursos motivacionais e materiais. Capacidade de armazenamento de memória, habilidades de percepção e produção e aptidão para ler estão 
em ambos os recursos. Os recursos são limitados e interligados no sistema dinâmico. A estrutura interligada desses recursos se refere ao sistema cognitivo. O sistema cognitivo se baseia em subsistemas que têm seus próprios papéis na linguagem e em seu desenvolvimento. São recursos cognitivos relacionados à linguagem: não só a capacidade de memória funcional e de longa duração, como também os processos de atenção e velocidade.

\subsection{O Speech Learning Model}

Uma série de estudos abordam a influência da idade na aquisição de uma segunda língua e, consequentemente, no sucesso desse processo. Flege, Schirru e MacKay (2000) apontam que a literatura na área de aquisição apresenta três definições para o efeito da idade na performance dos aprendizes de segunda língua: a primeira é, quanto maior a idade, menos efetivamente trabalhariam os mesmos mecanismos de aquisição de L1; a segunda é que os aprendizes de L2 em fase tardia receberiam menos input que aqueles em fase infantil; e a terceira estaria ligada à interação entre os sistemas linguísticos. Dessa forma, os falantes seriam capazes de evitar a influência de sua L1 na L2.

Discutindo a ideia postulada na terceira definição, Flege e outros estudiosos desenvolveram um modelo de aprendizagem intitulado Speach Learning Model (SLM), o qual procura entender a organização dos subsistemas fonéticos da L1 e da L2 em um espaço fonológico comum na mente do aprendiz e suas influências. O SLM também busca analisar de que maneira o fator da idade pode limitar ou influenciar na produção de vogais ou consoantes em uma língua-alvo. De acordo com a proposta, sem alvos claros para guiarem o sistema sensório-motor dos falantes aos sons da L2, a produção pode ser imprecisa. A ideia difere de outras propostas de aquisição de segunda língua. Weinreich (1957), por exemplo, se referia aos sons de L1 e L2 ligados perceptivamente como diafones. O modelo também pretende ser menos abstrato que a proposta da Análise Contrastiva (Lado, 1957), mas é, apesar disso, um modelo que usa da abstração. Flege (1995) propõe postulações ao modelo:

- Os mecanismos e processos usados na aquisição do sistema de sons da L1 incluem a formação de categorias que permanecem intactas durante a vida dos falantes e podem ser aplicadas à aprendizagem da L2;

- Os aspectos específicos dos sons da fala são especificados nas representações da memória de longa duração e chamados de categorias fonéticas; 
- As categorias fonéticas formadas na infância para os sons da L1 desenvolvem durante toda a vida as propriedades dos fonemas tanto da L1 quanto da L2, identificados de acordo com a realização de cada categoria;

- Os indivíduos bilíngues se esforçam para manter o contraste entre a L1 e a L2 em categorias fonéticas existentes em um espaço fonológico comum.

O SLM considera que a habilidade de aprendizagem da fala permanece intacta durante toda a vida dos falantes. Os efeitos da idade aparecem pela maneira como os subsistemas fonéticos da L1 e da L2 interagem. Assim, as categorias fonéticas usadas na percepção e na produção dos sons de palavras da L1 tornam-se mais especializadas e atrativas para o desenvolvimento de sons na L2 ao passo que a infância segue para a vida adulta (Walley e Flege, 2000). Assim, quanto mais vogais e consoantes da L1 se desenvolvem, mais haverá a assimilação desses sons na L2.

Flege (1981) indica três categorias de sons no processo de aprendizagem da L2 e seu relacionamento com o sistema da L1. Os sons idênticos nos dois sistemas, os sons diferentes e facilmente percebidos pelo aprendiz e aqueles semelhantes, especialmente nas diferenças acústicas, que podem causar maior dificuldade.

De acordo com o SLM, os sons da L1 e da L2 interagem por meio de dois mecanismos. O primeiro deles, intitulado assimilação categorias fonéticas, acontece quando o aprendiz não cria uma nova categoria para o som da L2, pois interpreta o som como parte de sua L1, como acontece com sons semelhantes. O segundo, intitulado dissimilação de categorias, ocorre quando o aprendiz cria uma nova categoria para o som da L2, tal qual acontece com sons diferentes à percepção.

Embora o SLM tenha recebido críticas, a proposta de levantamento de similaridades e diferenças entre LM e LE pode ajudar o aprendiz na aquisição dos sons. A grande discussão acerca da percepção e da produção: o que vem em primeiro lugar? Há diversos fatores no processo de aquisição de uma L2 que não são focos deste trabalho, mas que podem indicar estágios de conhecimento linguístico, estratégias de aprendizagem adequadas e, especificamente, ajudar no processo de produção e percepção da L2 por meio de experimentos, como se apresenta aqui.

\subsection{As teorias de protótipo: o modelo baseado no uso de Bybee}


Na tentativa de propor um novo modelo de descrição para os fenômenos fonológicos, Bybee (2001) rejeitou a ideia de que as regras linguísticas não apenas apareciam no léxico, contrariamente aos modelos estruturalista e gerativista. No estruturalismo, por exemplo, havia grande ênfase na sistematicidade da linguagem, reduzindo as complexidades das línguas a excertos de regularidade visíveis em enunciados gerais. Dessa maneira, o maior objetivo da análise linguística era determinar quais características linguísticas eram idiossincráticas e quais eram previsíveis à norma. As lacunas do modelo estruturalista trilharam o insucesso, uma vez que não há razão particular para crer que os falantes organizam a língua na mente dessa maneira.

Para tratar da assimilação de unidades fonológicas, a autora aponta que há várias correntes articulatórias e acústicas que formam um continuum, relacionando segmentos, sílabas e unidades rítmicas. Bybee (2001) diz que não há necessidade de fragmentar um discurso exaustivamente em unidades alfabéticas, mas, sim, indicar vogais puramente ou consoantes. Observando que as sílabas são vistas como a unidade básica de organização da articulação, Browman e Goldstein (1995) definem a estrutura silábica por um padrão característico entre gestos. Dessa forma, uma vez que a natureza e a duração de gestos são descritas, a estrutura silábica também é.

A natureza das regras simbólicas e de que forma essas se diferem de generalizações emergentes são intituladas esquema. Esquemas são altamente afetados pelo número de itens participantes, abrangendo padrões produtivos e improdutivos, e podem apresentar categorias ascendentes ou descendentes. Assim, os falantes podem apresentar um comportamento probabilístico, fixando formas de um esquema para o outro. Bybee (2001) aponta que, em contraste, as regras são secretas no comportamento desses falantes. Para a aquisição de línguas, similaridades entre trechos de fala podem guiar a uma noção não abstrata de possíveis sílabas para uma língua. A exemplificação dada pela autora surge a partir da palavra send,em inglês, podendo gerar um esquema muito local ou específico. Um esquema para uma rima, por exemplo, -end está em um nível mais geral de representação. Um esquema mais geral seria - vogal-nasalidade-vozeamento-pausa - ou ainda mais geral - vogal-sonoridade-pausa. A existência de um desses níveis de generalização de um esquema não impede que outros surjam.

É importante mencionar que o domínio sequencial dos esquemas é potencialmente aberto e apenas compelido pelo input, que determina quanto é necessário considerar como estrutura linguística. É claro que padrões ocorrem no uso linguístico e, como falantes, somos 
aptos a separar as propriedades necessárias da faculdade humana da linguagem das propriedades derivadas do input.

Bybee (2001) aponta que evidências de categorização prototípica são reportadas por vários níveis da estrutura linguística. O termo categorização prototípica é usado pela autora para se referir a uma categorização que não depende nem da presença nem da ausência de características discretas, mas da organização de sinais de experiências em grupos baseados na similaridade de um membro central. Miller (1994) mostra evidências de que a categorização de símbolos fonéticos tem uma estrutura prototípica com alguns símbolos sendo armazenados e categorizados mais ou menos como membros centrais de categorias.

Discussões sobre padrões fonotáticos são baseados não em regras abstratas, mas na frequência e nos padrões distribucionais de ocorrência de palavras em uma língua (PIERREHUMBERT, 1994). Os princípios sobre prototipicidade podem ser aplicados a todos os níveis linguísticos: sequências fonéticas, palavras, enunciados e, então, podem ser categorizados da mesma maneira de objetos não linguísticos (BYBEE, 2001). A estrutura das categorias é não discreta, e, dessa forma, os membros podem ser mais centrais ou marginais, a frequência da experiência influencia a importância das características particulares e essas características podem ser mais ou menos importantes na definição de uma categoria, entretanto nenhuma característica é redundante ou até mesmo dispensável.

\subsection{A aplicação das teóricas dinamicistas para a prosódia}

Observar a linguagem como um sistema dinâmico torna possível concebê-la como um todo formado por partes que, de forma não estática, interagem e evoluem temporalmente. Dessa maneira, Barbosa (2006) relembra da importância de teorizar o ritmo da fala como produto de um sistema dinâmico subjacente. A interação das partes desse sistema faz que sua evolução ocorra de forma adaptativa por meio de um princípio de auto-organização capaz de gerar séries complexas de padrões duracionais de unidades linguísticas.

Pensar no ritmo da fala de forma dinâmica leva à identificação do sistema rítmico que, para Barbosa (2006), separa os componentes prosódico e segmental, permitindo-os que interajam de maneira autônoma. Assim, o ritmo é visto como um produto desses dois sistemas. 


\section{OS ESTUDOS EM FONÉTICA ACÚSTICA}

Neste capítulo, apresenta-se o percurso da fonética acústica até os dias atuais e uma discussão acerca da relevância do uso da fonética acústica como ferramenta de análise linguística para os objetivos propostos.

\subsection{O surgimento e a repercussão dos estudos em Fonética Acústica}

Como um campo da Fonética, a fonética acústica surgiu na tentativa de identificar a fala como um processo complexo em que, por meio de uma análise perceptual de seus componentes, fosse possível identificar características peculiares dos sujeitos, tratando inclusive de pontos relativos à identidade como idade, origem linguística, interferências, dentre outros. São investigadas pela fonética acústica propriedades como a amplitude, a duração, a frequência fundamental e até mesmo o conteúdo espectral das ondas sonoras. Feita por meio de espectrogramas, a análise acústica retrata a forma da onda em gráficos, a trajetória dos formantes, dentre outras características.

Para Sapir (2004), há além do sistema objetivo dos sons, um sistema interior um pouco mais limitado que provavelmente não seja consciente para o ser humano. Esse sistema, um mecanismo mais psicológico, é coberto por um sistema mecânico. Sapir considerava que dois sistemas linguísticos podem não ter sons em comum, mesmo que seus sistemas fonéticos sejam idênticos. Para o estudioso, cada língua tem seus próprios modelos fonéticos e estruturas gramaticais e há uma natureza específica da expressão linguística caracterizada pela forma e estrutura da relação entre os elementos, que se concretiza por meio dos sons, a substância linguística.

Os pensamentos saussureanos já buscavam a concretização da língua na forma, não na substância. Saussure (1916) afirmou que nem sons, nem representações gráficas têm significações, o que de fato representam entre si é que têm validade. A Linguística enquanto ciência busca descrever as relações entre todos esses elementos.

Os estudos em fonética acústica tiveram evolução significativa após a invenção do fonógrafo, por Thomas Edson, em 1877. Através do fonógrafo, era possível gravar o sinal da 
fala e processá-lo para uma análise posterior. Depois desse invento, apareceram estudos voltados a espectrogramas e formantes.

Diferentemente da fonética articulatória, a fonética acústica estuda os sons de acordo com nossa percepção auditiva. Ladefoged (1993) afirma que a maneira como ouvimos os sons depende de sua estrutura acústica. É importante que haja uma descrição da natureza acústica para uma análise detalhada dos sons em função de explicar o porquê de alguns serem confundidos com outros, especificar principalmente vogais, que são difíceis de descrever por meio de movimentos articulatórios.

A fonética articulatória foi usada por muito tempo para descrever as línguas de maneira fisiológica, permitindo o entendimento dos órgãos do aparelho fonador e a descrição da articulação dos sons. Quilis (1988) indica que foi a partir da obra de Jakobson e Halle (1952) que foram estabelecidas oposições binárias baseadas em recursos acústicos, ainda que, desde o Círculo Linguístico de Praga, em 1929, já houvesse discussões acerca dos aspectos acústicos das línguas.

Embora a fonética acústica tenha grande relevância na atualidade, ainda levará muito tempo para atingir o estágio de pesquisas da fonética articulatória. O que é importante apontar é que uma não anula a outra, elas se complementam. A fonética articulatória é a origem da fonética acústica e nem por isso pode-se dizer que esta é estática. Quanto às semelhanças, pode-se dizer que as duas fonéticas estão envolvidas em um fenômeno de amplitude maior que o processo de comunicação: ambas trabalham com a identificação de fonemas. Quilis (1988) afirma que a realização acústica é a mais próxima do receptor da mensagem, é a que leva aos órgãos auditivos e se dirige ao cérebro. Já pelo ponto de vista articulatório, cada posição dos membros do aparelho fonador dá origem a sons diferentes.

Para exemplificar os contrastes entre as fonéticas acústica e articulatória, Quilis (1988) mostra como os manuais tradicionais de fonética apontam a diferença entre [s] e [J]. De acordo com esses materiais, pode-se dizer que o primeiro é alveolar e o segundo, alveolopalatal. O autor indica que o importante não é o ponto de articulação, mas a posição articulatória da língua para as duas consoantes. Na emissão de [s], a parte posterior do dorso da língua está baixa trazendo um movimento côncavo, enquanto para [J] está alta, trazendo um movimento convexo. As posições diferentes da língua originam diferenças dos ressoantes bucais e são essas diferenças de ressonâncias que correspondem à diferença acústica. Quilis (1988) indica que, pela fonética acústica, pode-se entender que isso acontece porque [s] tem uma frequência mais elevada que [J], dessa forma, entender a estrutura acústica dessas consoantes tem mais relevância que entender seus pontos de articulação. 


\subsection{As ondas sonoras}

Intitulado de fenômeno da compensação, o reconhecimento de duas posições articulatórias diferentes como mesmo fonema, sendo o resultado o mesmo espectro acústico, abre janelas para realizar a mesma imagem acústica de maneiras diferentes.

Embora os dados resultantes das pesquisas em fonética acústica sejam mais objetivos e constantes que os da fonética articulatória para a descrição fônica, não se pode dizer que uma é menos importante que a outra.

Quilis (1988) descreve o processo de comunicação como na Figura 1:

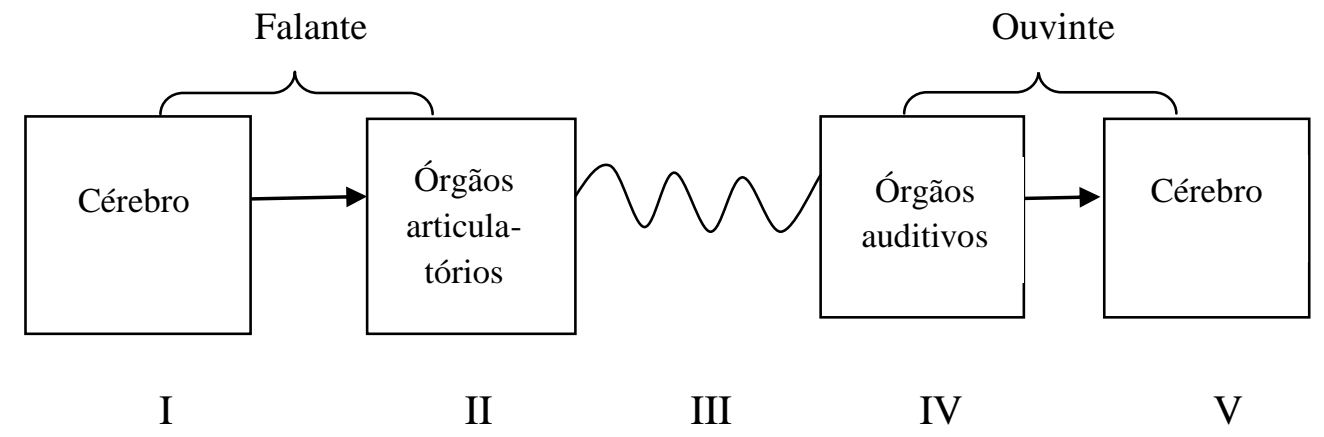

Figura 1: Esquema da comunicação humana sob a perspectiva de Quilis (1988)

Para explicar a Figura 1, Quilis (1988) identifica os números I e II como falantes, e IV e V como ouvintes. A fase III é o elo do veículo de comunicação. As fases I e V são fases psíquicas, já as fases II e IV são fisiológicas. A fase III, de interesse desta pesquisa, é a fase acústica, que se constitui de ondas acústicas complexas que formam cada um dos sons.

O ar é o meio de transmissão dos sons emitidos pelos órgãos do aparelho fonador. A produção dos sons passa por algumas fases: (1) a fase fonte, em que há a criação de um movimento em um corpo; (2) a fase de radiação, caracterizada pela comunicação desse movimento do corpo, servindo de transmissor; (3) a fase de propagação, em que o movimento é transmitido pelo ar; (4) a fase de recepção, em que esse movimento chega ao ouvido por meio da pressão das partículas no ar, no ouvido essa pressão age sobre os nervos auditivos, provocando uma sensação ao cérebro; (5) a fase de percepção, aquela em que há a interpretação das sensações que chegam ao cérebro. 
O som não se propaga no vácuo. Sua propagação no ar tem uma velocidade de aproximadamente $340 \mathrm{~m} / \mathrm{s}$ (metros por segundo). Em outros meios, como a água, essa velocidade sobe para $1.500 \mathrm{~m} / \mathrm{s}$.

Por meio da descrição das fases de produção e interpretação dos sons, pode-se afirmar que o som resulta da decodificação realizada no cérebro, promovida pelas vibrações recebidas pelos órgãos auditivos. Para que essas vibrações sejam realizadas, é necessário que sejam em forma de ondas sonoras.

As ondas sonoras são caracterizadas pelos ciclos com os quais ocorrem. O número de ciclos em dado tempo recebe o nome de frequência. Medida em Hertz e indicadora da quantidade de ciclos por segundo, a unidade recebe esse nome em homenagem ao alemão Heinrich Hertz, grande contribuidor para os estudos de eletromagnetismo. A distância entre a posição de repouso e o maior ponto de afastamento da onda sonora tem o nome de amplitude. É possível visualizar as definições dadas pela figura abaixo:

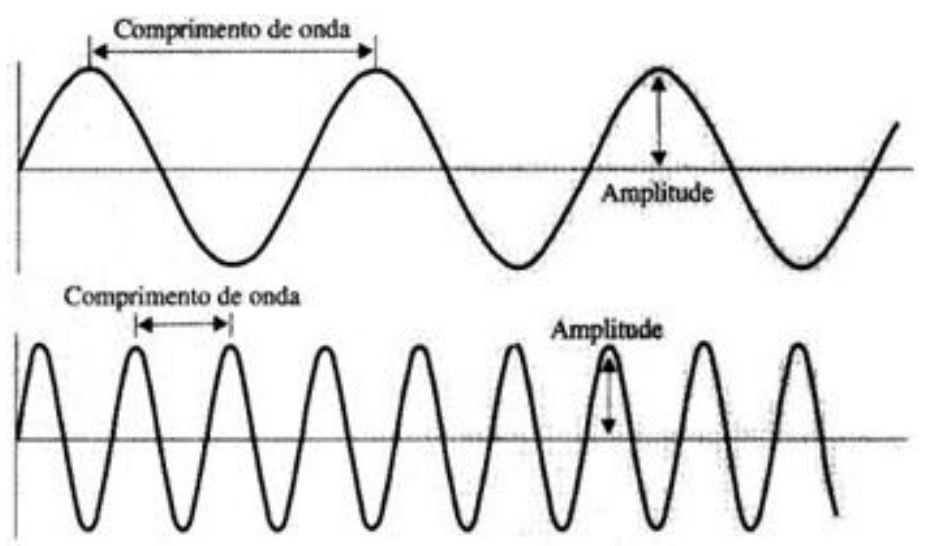

Figura 2: Comprimento e amplitude de onda ${ }^{3}$

A Figura 2 exemplifica uma onda simples. Entretanto, os sons linguísticos, foco deste trabalho, são caracterizados por ondas compostas, aquelas que resultam da soma de várias ondas simples. Quilis (1988) observa que o método de análise de ondas compostas surgiu com Furier, um matemático francês que em 1822 evidenciou que as ondas com repetição periódica podem ser decompostas.

Pode-se dizer que um som vocálico contém diferentes pitches simultaneamente. Há um pitch em cada enunciação e há vários pitches harmônicos que dão essas características distintivas pelas diferenças audíveis desses harmônicos. As vogais são distintas por dois

\footnotetext{
${ }^{3}$ Disponível em: http://www.fonologia.org/acustica_osom_2.php. Acesso em 19 de dezembro de 2014.
} 
pitches característicos chamados de formantes vocálicos. $\mathrm{O}$ mais baixo, intitulado primeiro formante e o mais baixo, de segundo formante. Também há um terceiro formante, mais difícil de ter o pitch demonstrado.

É possível analisar sons em que podemos medir a frequência dos formantes. Aqueles que caracterizam diferentes vogais são resultados de formas distintas do trato vocal. $\mathrm{O}$ ar nesse canal dá origem à vibração pela ação das cordas vocais. Sempre que as cordas vocais abrem e fecham, há um pulso de ar dos pulmões.

A onda mais longa que pode formar uma onda estacionária, com comprimento maior e menor frequência, é intitulada primeiro harmônico ou frequência fundamental, que determina a altura (pitch) do som. Na análise de dados desta pesquisa, utilizaremos o último termo como definição. Tom ou altura tonal é a impressão auditiva que temos da frequência fundamental, que pode ser alta ou baixa. Foco deste trabalho, do ponto de vista linguístico, a frequência fundamental tem função contrastiva, no nível da palavra, essa frequência recebe o nome de tom e, no nível do enunciado, de entoação, como ocorre nas línguas tonais africanas.

O timbre é caracterizado pelo número, audibilidade e conformação dos harmônicos. Dessa forma, podem ser graves, quando os harmônicos de maior amplitude são os mais baixos, e agudos, quando os harmônicos superiores têm uma amplitude maior.

Para Fant (1960 apud QUILIS, 1988), a onda da linguagem é a resposta dos sistemas de filtros do trato vocal a uma ou mais fontes de som. Por isso, a onda sonora linguística deve ser tratada com os termos fonte e filtro. $\mathrm{O}$ autor aponta que há uma relação entre os termos fonte e fonação, e entre articulação e filtro. A cavidade bucal, atuante como um tubo de ar, tem função de filtro. São os órgãos articulatórios que mudam de posição, formando na região superior à glote cavidades de forma e volume diferentes.

O fato de haver cavidades, também chamadas de ressonadores, diferentes traz respostas diferentes. É dessa maneira que se criam ondas sonoras diferentes, formando os diversos sons das línguas. Nas ressonâncias do trato vocal, os formantes são traços acústicos que determinam a qualidade dos sons. Pode-se intitular as frequências desses formantes de frequências formânticas.

Para diferenciar os sons de acordo com a maneira como ouvimos, há três formas que podem ser distintas ou iguais, são elas: o pitch, o volume e a qualidade dos sons. Ladefoged (1993) considera, que mesmo que duas vogais tenham exatamente o mesmo pitch e a mesma altura, uma pode ser [e] ou [o], por exemplo. Por outro lado, elas podem ter a mesma qualidade de vogais, mas se diferenciarem de acordo com o pitch: mais alto e mais baixo. 
Ladefoged (1993) afirma que os sons consistem em pequenas variações de pressão de ar que ocorrem bem rapidamente uma depois da outra. Essas variações são causadas pelos órgãos vocais dos falantes, que são na maior parte do tempo superimpostas pelo fluxo de saída do ar expelido pelos pulmões.

Em relação aos sons vocálicos, a vibração das cordas vocais corta o fluxo do ar dos pulmões que pulsam ora em alta pressão, ora em baixa. Nos sons fricativos, a corrente de ar é forçada através da abertura estreita que os turbulencia com irregularidades, ocorrendo picos de pressão. Os outros sons são produzidos com os mesmos princípios. Variações na pressão de ar, na forma de ondas sonoras, movem-se no ar como ondulações em um lago, como afirma Ladefoged (1993) metaforicamente. Quando as ondas alcançam os ouvidos, elas causam a vibração do tímpano. Um gráfico de uma onda sonora é muito semelhante ao gráfico dos movimentos do tímpano.

Nos espectrogramas, o eixo vertical representa a pressão do ar, relacionada à pressão do ambiente, enquanto o eixo horizontal representa o tempo, relacionado ao ponto de partida. Nem sempre é simples observar o formato das ondas e identificar os sons produzidos. As ondas de vários sons são bem similares e podem ser interpretadas apenas pela análise de seus componentes. Ladefoged (1993) observa que nos espectrogramas há uma clara diferença entre sons surdos e sonoros pela troca de padrões entre os tipos de sons, como as vogais, sons laterais e nasais.

\subsection{A entoação}

Para iniciar as discussões acerca da entoação, Ladd (2008) a define como um termo referente ao uso de características fonéticas suprassegmentais que transmitem sentidos pragmáticos às sentenças estruturadas linguisticamente. Ao tratar de características suprassegmentais, Ladd (2008) aponta que, para esses estudos, é preciso focar, tradicionalmente, na frequência fundamental (f0), na intensidade e na duração dos sons. Entretanto, não é possível fechar os olhos para os problemas trazidos pela restrição da definição.

Lehiste (1970) aponta, por exemplo, que os estudos suprassegmentais são definidos pelo pitch, o acento e a quantidade. Entre essa definição e a definição tradicional apontada por Ladd, há diferenças que envolvem propriedades físicas, psicofísicas e fonéticas. Ladd (2008) 
aponta que o acento é claramente uma propriedade fonética, enquanto a sonoridade é psicofísica e a intensidade, física. Distinções parecidas podem ser dadas no caso de pitch e f0, ou quantidade e duração. Ladd aponta que, em todos esses casos, há sempre confusão entre a escolha dos termos que devem ser usados mais apropriadamente ao se falar sobre o fenômeno suprassegmental.

Para evitar a discussão entre os termos, adotar-se-á a posição de Ladd (2008) de não fazer distinções rigorosas entre pitch e f0. Na análise, f0 será vista como uma propriedade física correspondente ao pitch, que é psicofísica.

Outro ponto importante é que, em muitas línguas, como nas tonais faladas pelos colaboradores dessa pesquisa, a entoação tem significação não apenas pragmática, mas também morfológica. Nesses casos, é necessário que haja distinção de análise não apenas no nível suprassegmental.

Ladd (2008) indica que a definição de entoação está relacionada aos sentidos dos enunciados e da elocução de maneira holística, como foco no discurso, no ato, no foco ou na estrutura na informação. Dessa forma, a entoação excluiria características de acento, tonicidade definidas pelo léxico. Entretanto, foneticamente, essas características interagem com as entoacionais de múltiplas maneiras.

Os aspectos entoacionais são organizados distintamente em unidade, por meio das fronteiras de tons, e por suas relações, como fortes ou fracos. $\mathrm{Na}$ análise desses aspectos, não são considerados os aspectos paralinguísticos, que podem variar por seus parâmetros físicos, como o tempo e a sonoridade, embora esses possam interagir com a entoação.

\subsection{Pitch e frequência}

Ladefoged (1993) afirma que o pitch de um som depende da taxa de vibração das cordas vocais. Em um som com o pitch alto, há uma frequência mais alta na vibração que no pitch baixo. Devido à abertura e ao fechamento das cordas vocais, há um pico de pressão de ar na onda sonora. O pitch de um som pode ser observado pela taxa de ocorrência dos picos na onda sonora.

Já a frequência é um termo usado para uma propriedade acústica dos sons, ou para o número de repetições completas (ciclos) de variações de pressão de ar por segundo. O pitch de um som é a propriedade auditiva que habilita o ouvinte a colocá-lo numa escala de baixa 
para alta sem considerar diretamente as suas propriedades acústicas. Quando a frequência do som aumenta, o pitch sofre reflexos, aumentando também. O mesmo som pode ser equivalente em três dimensões: 1) articulatória: vibrações das pregas vocais; 2) auditiva: pitch; 3) acústica: frequência fundamental (f0) (FIORIN, 2011, p.12). Ladefoged aponta que alguns autores não fazem distinção para esses termos, usando pitch tanto para a propriedade auditiva quanto para os atributos físico-acústicos.

É possível determinar a frequência de um som contando os picos de pressão de ar na gravação das ondas. A observação dos picos na onda sonora é uma boa forma de determinar a frequência da vibração das cordas vocais na elocução. Os programas de computador, como os atuais, possuem displays gráficos e algorítimos automáticos que permitem facilmente a identificação e a medição do pitch, respectivamente.

Fonemas sonoros têm ondas regulares que aumentam a precisão da sensação do pitch. Para a voz masculina, Ladefoged (1993) afirma que a frequência da vibração das cordas vocais no discurso pode ocorrer entre 80 e $200 \mathrm{~Hz}$, para a feminina, a frequência pode ir além de $400 \mathrm{~Hz}$. As frequências predominantes em sons surdos, por exemplo, são frequentemente acima de $200 \mathrm{~Hz}$.

Em geral, o volume de um som depende do tamanho das variações na pressão de ar que ocorre. Como observado, a frequência fundamental (f0) é a medida acústica mais diretamente relacionada ao pitch do som. Na mesma medida, então, temos que a amplitude (em decibel - dB), na dimensão acústica, é a medida mais apropriada correspondente à intensidade (ou volume)_ de um mesmo som, na dimensão auditiva. Assim, como sensação de intensidade se tem a variação forte/fraco (FIORIN, 2011, p.12). Para Ladefoged (1993), a intensidade é proporcional ao tamanho médio ou amplitude das variações na pressão de ar.

$\mathrm{O}$ autor considera ainda que as vogais têm maior intensidade e, por isso, são mais notáveis nos espectrogramas. Entretanto, afirma que a intensidade de um segmento depende de vários fatores, como sua posição na sentença, o nível de tonicidade em cada palavra e até mesmo de características particulares dos falantes.

O volume e a frequência são evidenciados em espectrogramas em escalas de decibéis (dB) e Hertz (Hz), como mencionado anteriormente. Tecnicamente, a medida de frequência em $\mathrm{Hz}$ não é uma maneira adequada de medir o pitch sem que se possa mostrar que as medidas de frequência estão relacionadas a como as pessoas percebem o pitch. Para Ladefoged (1993), são bases para a medição de frequência: (1) a indicação válida do pitch, uma vez que é notável por meio de vários procedimentos que o pitch está relacionado à frequência; (2) a confiabilidade, já que os instrumentos foram calibrados, então, sabe-se que o 
nível de precisão de cada frequência medida, e (3) a medição significativa, por que se faz um número significativo de medições, então, sabe-se que a média aumenta nessas circunstâncias. A funcionalidade das análises acústicas permeia o estudo de vários problemas fonéticos.

\subsection{As discussões acerca da Teoria Métrica Autossegmental (MA)}

O Institute for Perception Research (IPO), em Eindhoven, trouxe inúmeras contribuições para os estudos de entoação desde 1965. Ladd (2008) afirma que, a princípio, os estudiosos buscavam encontrar um modelo de entoação da língua holandesa para que fosse usado na síntese discursiva. Posteriormente, a abordagem IPO desenvolveu uma teoria ampla para a estrutura entoacional não apenas do holandês, mas de outras línguas. Esses estudos iniciais serviram de base para análises do inglês, do alemão, do russo, do francês e do indonésio. A abordagem veio caindo em desuso devido aos objetivos do instituto, que foram redirecionados. Não se pode deixar de mencionar, entretanto, as grandes conquistas alcançadas pelos pesquisadores, que abriram portas com seus trabalhos iniciais sobre o nível fonológico abstrato e o detalhamento da realização fonética dos elementos fonológicos.

A teoria mais discutida atualmente é a teoria MA. Ladd (2008) aponta que o surgimento dos debates acerca do tema se deu por meio das teses de doutorado de Liberman (1975), Bruce (1977) e, principalmente, Pierrehumbert (1980). Aplicada em diversas línguas europeias, a teoria MA serviu de base para inúmeros sistemas de síntese de entoação por regra. Sob essa visão, foi primordial o desenvolvimento de uma fonologia de laboratório, em que desde cedo se adotou o objetivo de explicar detalhada e instrumentalmente as medidas de f0 na descrição fonológica. Assim, seguramente, é possível usar instrumentos fonéticos como fonte de dados para a teoria fonológica. Foram desenvolvidos softwares como o Praat e até mesmo séries de sistemas como o ToBI (BECKMAN et al, 1994), que promovem a transcrição de sistemas de entoação de várias línguas com bases amplas para discussões sobre a estrutura prosódica e a relação entre entoação e informações provenientes de suas estruturas.

Para Ladd (2008), a teoria MA tem o objetivo de promover a caracterização dos contornos adequadamente nos termos da curva melódica e da caracterização dos elementos que a compõem. Ao contrário da abordagem IPO, que possuía bases na percepção do discurso, a teoria métrica autossegmental tem foco além dos problemas fonológicos, pois 
abrange a problemática da estrutura suprassegmental que motiva previamente o trabalho autossegmental, como nas línguas tonais africanas deste estudo.

Embora grandes discussões tenham acontecido fortemente na década de 1970, a teoria MA ganhou força após as propostas de Abercrombie (1991), que trouxe à tona discussões acerca da terminologia stress e pitch accent ${ }^{4}$, $e$ Ladd (1996). Para Ladd (1996), o objetivo fonológico da teoria MA é abrir caminhos para a caracterização de contornos de maneira adequada, ainda que se trabalhe com elementos distintos categoricamente. O objetivo fonético da teoria MA é, então, oferecer aos estudos na área um mapeamento dos elementos fonológicos para alcançar parâmetros acústicos contínuos.

Consoante à descrição de Ladd (1996), são quatro os princípios da teoria MA: (1) a sequencialidade da estrutura tonal; (2) a diferenciação entre pitch accent e stress; (3) a análise dos pitch accents quanto à altura dos sons, sendo os níveis básicos $\mathrm{H}$ (high) e L (low); e (4) a comparação entre características mais particulares, relacionadas à altura, a padrões mais gerais.

Chama-se aqui a atenção para o segundo princípio: a distinção entre pitch accent e stress. Quanto ao pitch accent, Ladd (1996) aponta que, mesmo que nem todas as línguas apresentem ocorrências desse fenômeno, ele indica a proeminência, enquanto o stress aponta para o acento lexical.

A dicotomia entre stress e pitch accent também levanta outras questões. Entretanto, a noção de acento usada neste trabalho se refere à unidade entoacional mais perceptível, como adotado por Bolinger (1972) e Hyman (2014) na literatura métrica.

Hulst (2014), por exemplo, indica que o stress está ligado à dinamicidade e o pitch accent, à melodia. As definições são complementares no uso de seus expoentes fonéticos. $\mathrm{O}$ autor explica que, mesmo até os dias atuais, o acento não é uma propriedade bem definida nos estudos linguísticos. Em sua análise, o acento tem características fonéticas e fonológicas. Os expoentes fonéticos incluem a duração, as vogais não reduzidas e o pitch, que juntos compõem a tonicidade. Como expoentes fonológicos, o autor indica a duração, o contraste entre vogais e a altura.

Hyman (2014) questiona se todas as línguas possuem marcas de posições mais proeminentes nas palavras e indica que um número considerável e, provavelmente, a maioria evidencia o fenômeno do acento. Muitos estudiosos assinalam a falta de acento em certas línguas africanas tonais e até em línguas não tonais. Newman, por exemplo, (1947) indica que

\footnotetext{
${ }^{4}$ Pela frequência desses termos na literatura acerca do tema, será mantida a terminologia em língua inglesa.
} 
na língua bella coola, falada em território canadense, não há o fenômeno do acento e do pitch associado a sílabas ou palavras, assim, quando duas ou mais sílabas ocorrem em uma palavra ou sentença, a distinção é feita apenas pela força articulatória.

Por outro lado, muitas línguas não evidenciam ambiguidade na questão do acento e é importante ressaltar que as teorias para esses estudos são independentes e até mesmo pessoais: algumas pessoas notam o acento e outras, não. Assim, Hyman (2014) afirma que é extremamente difícil demonstrar acentos e ainda mais falar sobre universais para eles.

Para uma definição mais precisa de acento, adotar-se-á neste trabalho as propriedades concedidas por Hyman (2014) para o fenômeno. Assim, considera-se que:

- A localização do acento não pode ser reduzida à primeira ou segunda sílaba das palavras (que frequentemente representam as fronteiras);

- Sílabas tônicas evidenciam efeitos de proeminência devido à posição: consoantes, vogais e contrastes de tons são mais comuns em sílabas tônicas; os segmentos ganham mais força em sílabas tônicas;

- Sílabas átonas evidenciam efeitos de posição não proeminentes: consoantes, vogais e contrastes de tons são menos comuns em sílabas átonas e segmentos são enfraquecidos também nessas sílabas;

- O acento evidencia efeitos cíclicos;

- O acento evidencia efeitos rítmicos lexicalmente ou pós-lexicalmente, como ocorre com o inglês;

- O acento no nível lexical interage com o nível frasal;

- O acento lexical fornece elementos para a atribuição de tons entoacionais;

- Outros argumentos de que cada sílaba é um constituinte métrico podem ser mencionados.

\subsection{Questões tipológicas sobre a tonicidade das línguas}

Hulst e Smith (1988) afirmam que uma divisão simples de línguas não tonais e línguas tonais seria uma simplificação brusca de fenômenos. Assim, o mais cabível seria enquadrá-las em um continuum de línguas mais tipicamente tonais ou mais tipicamente de não tonais. Hulst e Smith procuram identificar como as línguas flutuam nesse continuum. 
Hulst e Smith (1988) sugerem que, em uma abordagem de sistemas entoacionais, os contornos são limitados a um conjunto de movimentos de pitch. Pike (1948) definiu línguas tonais como aquelas que possuem significado léxico, contrastivo e relacionado ao pitch de cada sílaba. Hulst e Smith (1988) criticam a definição de Pike, uma vez que quase todas as línguas têm pelo menos algumas sílabas em que o tom não é contrastivo, embora previsível pelo ambiente. Uma definição mais ajustada é a de Welmers (1959), que indica que línguas tonais são línguas em que tanto fonemas com pitch quanto fonemas segmentais se encaixam na composição de, pelo menos, um morfema.

\subsection{A estabilidade dos onsets das vogais na fala: a duração das unidades VV}

Em seu livro, "Incursões em torno do ritmo da fala", Barbosa (2006) apresenta, por meio de experimentos, uma característica primordial da organização temporal das vogais: a preservação do seu onset. Indicando a presença de um fluxo vocálico contínuo nas línguas como o inglês e o sueco, Barbosa afirma que, para línguas de ritmo distinto, como o francês e o PB, há o argumento da homogeneidade duracional das unidades VV. Considera-se uma unidade VV o segmento acústico de um onset vocálico até o seguinte. Vale ressaltar que estão inclusos nesses segmentos até mesmo constituintes assilábicos.

Barbosa (2006) considera a unidade VV como integrante da prosódia. De acordo com seus estudos, a duração desses segmentos está intimamente ligada ao ritmo do PB. Para o autor, a periodicidade das unidades VV na cadeia da fala "está intimamente relacionada à observação de que a enunciação se dá pela produção continuada de vogais interrompidas ou perturbadas marginalmente pela realização das consoantes” (BARBOSA, 2006, P.31).

O valor duracional das unidades VV tem grande relevância para a análise de dados deste trabalho e é considerado como determinante do ritmo do PB.

\subsection{A entoação no processo de aquisição da linguagem}


A entoação abrange todos os aspectos percebidos pelos padrões de pitch que os falantes procuram usar entendendo os padrões de pronúncia, fazendo esses usos controladamente ou não (Beckman, 1995). Considerando a aquisição de primeira língua, há autores como Kuhl e Iverson (1995), que consideram as propriedades prosódicas como adquiridas desde o útero. Afirmações como esta evidenciam um contato não consciente com a entoação, se compararmos a outros segmentos. Entretanto, também há estudos os quais indicam que a percepção dos traços suprassegmentais integram uma parte importante da capacidade humana de percepção da fala. Assim, Clark e Yallop (1995) afirmam que os humanos têm a capacidade de discernir mudanças de apenas 0,5\% na frequência. Dessa forma, alterações em frequências inferiores a $1000 \mathrm{~Hz}$ são importantes para notar movimentos importantes de f0, ou seja, de entoação, ao mesmo tempo em que mudanças acima de $1000 \mathrm{~Hz}$ são indispensáveis para diferenciação de formantes para as categorias segmentais.

Mesmo que se saiba que a prosódia e a entoação contribuam para a aquisição de uma segunda língua, há muitos estudos voltados apenas para o sotaque. Há uma gama de pesquisas voltadas para os aspectos segmentais na aquisição de segunda língua. Por isso, é importante que haja estudos contrastivos de entoação que contribuam para a pesquisa entoacional do contato entre línguas. Infelizmente, existe uma escassez de trabalhos voltados para a prosódia e entoação bem vinculados a conceitos consistentes sobre a aquisição de segunda língua.

Um estudo de grande pertinência é o de Barbosa (2006), que inclui aspectos significativos da prosódia do português e do francês, como a magnitude do movimento do pitch na ascensão final do pitch, a realização de acentos, as diferenças no contorno do f0 associadas a contextos tonais frasais em situações discursivas específicas, o onset mais alto do português no início da frase entoacional, dentre outros.

É a percepção do nativo que torna possível a identificação de um desvio entoacional de um não nativo. Para Jilka (2000), se um desvio entoacional é encontrado em uma das enunciações de um sujeito de pesquisa, isso ocorre devido ao sotaque. Muitos aspectos adicionais de variação entoacional precisam ser levados em conta, já que a variação não atinge apenas a escolha e distribuição de categorias tonais, mas inclusive a realização fonética da categoria.

É necessário refletir sobre um protótipo entoacional, dessa forma, as enunciações podem ser vistas como diferentes, mas não como estrangeiras. Assim, é possível explicar que as categorias entoacionais podem ter realizações fonéticas que variam com o contexto. Vários desvios de colocação de acento ou até mesmo escolhas inadequadas de acento de pitch podem nem ser notados pelo falante de segunda língua devido a interpretações diferentes. 


\section{PANORAMA DAS LÍNGUAS AFRICANAS}

Este capítulo traz o percurso linguístico do continente africano, mencionando as influências das línguas de colonização e um retrato linguístico das famílias e subfamílias faladas na atualidade. Nas subseções, há descrições das características segmentais e suprassegmentais das línguas da subfamília nigero-congolesa, faladas pelos colaboradores desta pesquisa.

\subsection{O percurso linguístico da África}

Os estudos sobre o continente africano remetem à antiguidade da escrita por suas origens: os primeiros relatos históricos foram produzidos principalmente em árabe, mas há publicações em francês e inglês. Dentre os grandes historiadores da África, está Ibn Khaldun (1332-1406), um norte-africano nascido em Túnis. Para Fage (1981), nenhum estado africano poderia manter a identidade e a integridade sem que houvesse uma tradição reconhecida sobre sua origem e desenvolvimento.

A escrita árabe chegou à Africa com o Islã, que atravessando o Saara avançou pela costa oriental africana. Dessa forma, os textos escritos passaram a ser instrumento de conservação da história. Os manuscritos árabes e sua difusão não isentam a existência da língua semítica, falada na África tropical (atual Etiópia). Na língua semítica, inicialmente falava-se o gueze e posteriormente o amárico, língua que teve suas tradições registradas por aproximadamente dois mil anos. Dentre as obras históricas mais conhecidas, há História das Guerras, de Amda Syôn, do século XIV. Os registros da história da África feitos em outras línguas africanas, como o haussa e o swahili, apareceram apenas em meados do século XIX.

Fage (1981) aponta que a costa da Guiné foi a primeira região africana em contato com os europeus. $\mathrm{O}$ foco na região era o fornecimento de mercadorias e o espaço funcionava como um motor para as atividades europeias. Como a região era visada apenas pelo comércio, os europeus não se sentiam incitados a interferir na sociedade africana, mas apenas observála, com exceção dos missionários, que se sentiam no dever de interferir no que encontravam.

$\mathrm{Na}$ região do baixo Congo, na Angola, bem como no vale do Zambeze e arredores, havia mais que interesse na evangelização. Entretanto, o que a sociedade africana podia 
receber não era suficiente aos desejos europeus e, dessa forma, os africanos sofriam fortes pressões. Os povos europeus consideravam que o estudo e documentação de sociedades não europeias não eram dignos de apreciação. Esse pensamento é fruto de correntes, como o Renascimento, o Iluminismo e a crescente revolução científica e industrial. Para os europeus, os africanos eram vistos apenas sob a ótica do tráfico de escravos, que gerava cada vez mais o caos no continente.

Em Filosofia da História, Hegel (1770-1831) posicionou-se afirmando que a África não era um continente histórico e que não demonstrava nem mudança, nem desenvolvimento. Além disso, apontou que os povos negros não eram aptos ao desenvolvimento e à educação.

Mesmo que a influência de Hegel não tenha sido forte na construção da história da África, seu posicionamento foi aceito pela ortodoxia histórica e até hoje conta com adeptos. Ao contrário disso, alguns europeus no início do contato possuíam um anseio de registrar e coletar tudo o que pudessem sobre o passado dos povos africanos, organizando documentos orais e escritos.

Em 1923, A. P. Newton afirmou que a África não possuía história antes da chegada dos europeus, justificando que só há história quando o homem branco começa a escrever. Para ele, só era possível reconstituir o passado da África por meio de resquícios materiais das línguas e dos costumes primitivos. Dessa forma, o papel não era dos historiadores, mas, sim, de arqueólogos, linguistas e antropólogos.

Tratando de línguas africanas, Seligman (1930) afirmou que as civilizações existentes na África são de origem camita, do norte da África, com a interação entre duas raças africanas, a negra e a bosquímana. Essa afirmação é passível de análise: para Fage (1981), não há provas de que as civilizações da África são as civilizações de camitas e ainda que o progresso histórico seja resultante dessa influência.

Greenberg (1963) demonstra que não há sentido nos termos camita e camítico, a não ser que se trate de uma classificação linguística. Os linguistas modernos evitam o emprego do termo "camítico". Há uma classificação das línguas que integrariam esse grupo, bem como as línguas semíticas, em um grupo maior: o afroasiático, também chamado de eritreu. Greenberg afirma (1963) que não há necessariamente uma ligação entre a língua falada por uma população e sua origem racial ou cultural. Essa refutação à língua camítica é dada principalmente sobre os estudos da subsubfamília bantu. Dentre os nomes que trouxeram contribuições notáveis à linguística africana, pode-se citar Harry Johnston, Maurice Delafosse e Westermann, que publicou em 1952 um estudo precursor ao de Greenberg sobre as línguas 
da África, e grande contribuidor à obra de Baumman. Entretanto, nota-se em seus escritos uma visão deturpada da teoria camítica.

\subsection{A diversidade linguística da África}

É adequado afirmar que as línguas humanas são partes indissociáveis da cultura de um povo e que a diversidade linguística é uma riqueza. Mesmo que haja tamanha heterogeneidade, as línguas constituem ao mesmo tempo unidades e diversidades. Unidades por serem meio de contato dos povos e diversidades por contrastes de ordem social, geográfica e de faixa etária, por exemplo.

A extensão do continente africano conta com $30.310 .000 \mathrm{~km}$. Nessa vasta amplitude territorial, há uma das maiores diversidades linguísticas do mundo. Kukanda (2000) aborda as línguas africanas em diferentes níveis linguísticos. Sua classificação linguística reúne as línguas autóctones em quatro grandes famílias: a congo-kordofaniana, a nilo-sahariana, a afroasiática e a khoisiana.

A família congo-kordofaniana é subdivida em duas famílias: a nigero-congolesa, que vai do Senegal até a África do Sul, aproximadamente, abrangendo toda a parte leste do continente desde o sul da Somália, e uma segunda subfamília (não intitulada por Kukanda) que é limitada a aproximadamente 20 línguas faladas por comunidades pequenas que habitam Nuba, nas montanhas da República do Sudão. Kukanda (2000) afirma que havia aproximadamente 300 milhões de falantes das línguas da família nigero-congolesa.

A família Nilo-Saariana, para Kukanda (2000), está espalhada por uma distância de aproximadamente $6.000 \mathrm{~km}$ de leste a oeste da África. As línguas dessa família estão localizadas no Níger, em Burkina Faso, Tchad, Etiópia (oeste) e também no Sudão. Dentre as línguas mais conhecidas da família nilo-saariana, pode-se citar o dinka, o shilluk, o nuer, o massai e o mangbetu, falado no nordeste da República Democrática do Congo.

Já a família afroasiática abrange exclusivamente línguas faladas na Ásia e o semítico, que inclui o hebraico e o árabe. Com as conquistas muçulmanas árabes dos séculos VII e VIII, essas línguas se difundiram e se enraizaram no norte do continente africano.

Kukanda (2000) considera que as línguas regionais possuem função veicular e que, muitas vezes, podem se sobrepor às línguas autóctones locais mesmo que coexistam 
geograficamente. Observando essas línguas, é possível notar suas subdivisões geograficamente.

Ao norte, há o árabe na região habitada pelos muçulmanos. Kukanda considera o árabe como língua litúrgica, pois foi trazida pelo Islã aos países da África Subsaariana. Ao oeste, são falados o wolof, na região do Senegal e da Gâmbia e usado pela administração e comércio local; o manding, representado pelos dialetos bambara, diula e malinké, que são falados no Mali, em grande parte da Costa do Marfim, em Burkina Faso, em Guiné Bissau, Guiné Conakri e Serra Leoa; o Haussa, falado ao norte da Nigéria, em Gana, no Togo na República do Níger e em cidades como Dakar, Freetown, Abidajan, Duala, Yaundé, Brazzavile e Tripoli; o ewe é falado em Gana, na Nigéria, no Togo e no Benim; o iorubá é falado no Benim e na Nigéria, onde é uma das línguas de maior relevância; o Igbo também é falado na Nigéria e abrange um vasto conjunto de dialetos.

Ao centro, são falados o fang, em Camarões, na Guiné Equatorial, no Gabão e na República Democrática do Congo; o lingala, a língua das capitais congolesas Kinshasa e Brazzaville, falada pelo exército da República Democrática do Congo e de grande representação musical; o kikongo, falado na Angola, no sudeste da República Democrática do Congo, no centro e no sul do Congo, no Gabão e no Burundi; e o luba, falado anteriormente no leste do Congo na colonização. Nos dias atuais, há uma quantidade reduzida de falantes de luba se comparado ao swahili.

Ao leste do continente africano, há a predominância do swahili, considerado por Kukanda (2000) a língua veicular bantu de maior relevância. Geograficamente, essa língua abrange o Quênia, Moçambique, a Tanzânia, Uganda, Ruanda, algumas ilhas da Zâmbia e o Malawi. No contexto internacional, o swahili é objeto de estudo de várias universidades e tem difusão em muitos meios de comunicação. O bemba é intitulado por Kukanda (2000) como língua veicular falada na Zâmbia. Já o macua, que tem em média 2.500 falantes, é falado em Moçambique e no Malawi. O shona é um exemplo de koiné ${ }^{5}$ e resulta do contato entre o korekore, o zezuru e o karanka, ocorrido na $1^{\text {a }}$ Guerra Mundial. É falado no Zimbábue e no Moçambique.

\footnotetext{
${ }^{5}$ Para Teixeira (2012), uma koiné é resultado do contato de várias línguas, tornando-se uma língua mais simplificada com funcionalidade veicular entre os povos.
} 
Ao sul, a língua zulu é falada no sudeste da África do Sul. Como pidgin 6 , foi chamado de fangalo e é usado em Joanesburgo como meio de contato de mineiros imigrados do Zimbábue e da Zâmbia.

\subsection{O contato europeu com as línguas africanas}

O povo europeu trouxe à África um contexto linguístico extremamente complexo. Esse contato deu origem às línguas crioulas ${ }^{7}$ e manteve as línguas europeias. Quanto às formas crioulas, Kukanda (2000) constatou que as línguas apresentadas foram o Inglês, usado pelos colonos na Libéria e na África do Sul, havendo uma forma crioula, o krio, em Serra Leoa; o afrikaans, uma manifestação do neerlandês trazida pelos colonos holandeses na África do Sul; o espanhol, com influência apenas nas Ilhas Canárias; e o português, na forma crioula, é parte das comunidades linguísticas de Cabo Verde e São Tomé e Príncipe.

Com a colonização, as potências trouxeram políticas linguísticas consoantes aos seus interesses. As línguas de maior influência foram o inglês, o francês, o português e, em menor difusão, o espanhol. Essas línguas, usadas como línguas de dominação, mantiveram-se conservadas após as independências como línguas oficiais, permitindo que houvesse uma comunicação aberta entre os países.

É importante ressaltar que essas línguas de dominação pertencem à mesma família e, ainda assim, trouxeram modificações distintas à realidade africana. Hoje esses países integram organizações como a Organisation Internationale de La Francophonie (AIF), a Comunidade dos Países de Língua Portuguesa (CPLP) e Países Africanos de Língua Oficial Portuguesa (PALOP).

A situação atual das línguas africanas oficiais é descrita por Kukanda (2000) separadamente. O inglês possui papel de destaque no continente africano, pois é falado em 19 países e influencia muitos outros, como Moçambique, a República Democrática do Congo e Ruanda.

\footnotetext{
${ }^{6}$ Para Crystal (1985), os pidgins ocorrem quando duas comunidades linguísticas tentam se comunicar,cada uma delas trazendo traços mais aproximativos de suas línguas. Todo pidgin é formado por uma motivação por parte dos falantes.

7 "Por crioulização entende-se a formação de uma língua crioula, uma vez que sobre esta não há a menor sombra de dúvida de que se trata de uma língua plena, como qualquer outra.” (COUTO, 2009).
} 
Já o francês, língua oficial em 17 países e em mais oito, como segunda língua oficial, é mencionado por Kukanda (2000, p.108):

\begin{abstract}
A sua adopção recentemente como língua oficial pela Guiné Equatorial, por exemplo, deve enganar. A criação da Organisation Internationale de La Francophonie não mudou nada nessa situação e os africanos francófonos têm actualmente tendência a tornarem-se bilíngues com a aprendizagem do inglês. Esse quadro não vai mudar apesar do lançamento de vários programas de promoção do francês, em diferentes domínios, apoiados pela Francofonia. (KUDANDA, 2000, p.108)
\end{abstract}

Sobre o português, Kudanda (2000, p.108) relata sobre a pressão dos vizinhos quanto às línguas oficiais:

\begin{abstract}
A Guiné-Bissau está completamente cercada por vizinhos que têm o francês como língua oficial. No plano interno, o crioulo exerce também uma pressão sobre a língua portuguesa [...] São Tomé e Príncipe está numa zona onde dominam o inglês e o francês [...] Angola tem quatro vizinhos dos quais os dois ao Norte (RDC e Congo) e os dois outros ao sul e ao leste têm respectivamente o francês e o inglês como línguas oficiais. Quanto ao Moçambique, ele é completamente rodeado por países anglófonos (Tanzânia, Malawi, Zâmbia, Zimbábue, África do Sul, Swazilândia. (KUDANDA, 2000, p.108)
\end{abstract}

Com o contexto linguístico dos países lusófonos, foi necessário buscar soluções que incluíssem a utilização do inglês nas regiões de contato, como se vê em Moçambique e em Angola, por exemplo. Já a proximidade da República Democrática do Congo, do Gabão, do Senegal e da Guiné Conakri faz com que haja influências ao norte de Angola, a São Tomé e Príncipe e a Guiné-Bissau. A única pressão exercida sobre Cabo Verde vem do crioulo, pois o espanhol só é usado, como primeira língua, na Guiné Equatorial. Na África Subsaariana, há o domínio da família congo-kordofan. Desta família surge a nigero-congolesa, uma subfamília evidente por meio das línguas bantu, presente em um terço da África. A área das línguas bantu vai de Camarões à África do Sul, aproximadamente.

Kukanda (2000) considera que há, em média, 200 milhões de falantes das línguas bantu. Da África negra, essas línguas integram o conjunto linguístico de maior relevância da África, se vistas geográfica e demograficamente. De maneira geral, as línguas bantu são faladas em Camarões, na República Centro-Africana, na Guiné-Equatorial, no Gabão, em São Tomé e Príncipe, no Congo, na República Democrática do Congo, em Ruanda, no Burundi, em Uganda, no Quênia, na Tanzânia, em Angola, na Zâmbia, em Mauari, em Moçambique, em Comores, na Namíbia, em Botsuana, no Zimbábue, em Suazilândia, em Lesoto e na África do Sul. 
Os países situados na zona bantu são necessariamente multilíngues. As crianças da República Democrática do Congo, por exemplo, falam em sua maioria três línguas: a língua materna (de sua etnia), a língua regional (o lingala) e o francês, ensinado na escola. É importante ressaltar que falar de monolinguismo na África é até irreal, pois há no continente um amplo universo linguístico.

\subsection{A classificação tipológica das línguas africanas}

No contexto etnolinguístico atual, há duas classificações das línguas africanas de grande relevância: a de Guthrie (1948) e a de Greenberg (1955). Observando a classificação tipológica proposta por Greenberg (1955), as línguas podem ser aglutinantes, isolantes ou flexionais. Nas línguas africanas, só é possível identificar uma dessas três tipologias: a aglutinante.

As línguas aglutinantes apresentam delimitações claras entre raízes e afixos, como se observa nas línguas bantu, especificamente em Lingala, de acordo com Angenot e Amaral (2009)

As línguas não são agrupadas de acordo com seus traços fonéticos, fonológicos, morfológicos ou sintáticos. Guthrie (1948) explicou o funcionamento das línguas africanas pela instituição de grupos linguísticos intitulados zonas. Ao todo são 16 zonas, 78 grupos linguísticos e 650 línguas bantu (sem incluir seus dialetos). Observando o mapa abaixo (BASTIN, 1978), é possível observar as delimitações de Guthrie na Figura 3: 


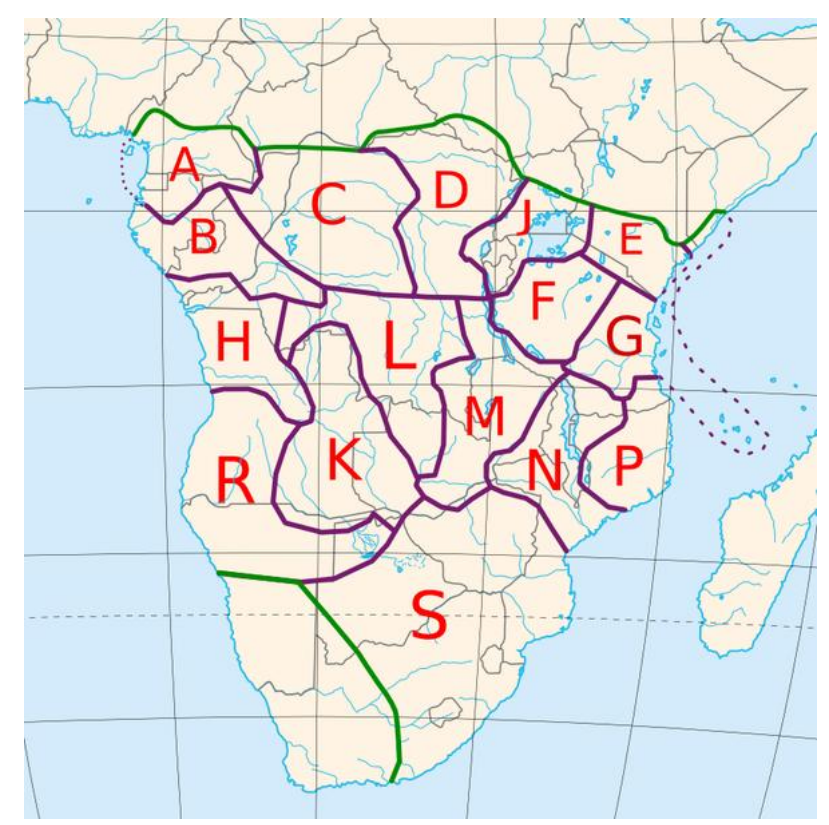

Figura 3: Divisão das zonas bantu por Bastin (1978)

Para Guthrie (1948), as línguas bantu são assim dividas:

- Zona A: com nove grupos, abrange Camarões, Guiné Equatorial, Gabão e Congo;

- Zona B: com oito grupos, abrange Gabão, Congo e República Democrática do Congo;

- Zona C: com nove grupos, abrange o Congo e a República Democrática do Congo;

- Zona D: com nove grupos, abrange o Congo;

- Zona E: com sete grupos, abrange o Quênia e a Tanzânia;

- Zona F: com três grupos, abrange a Tanzânia;

- Zona G: com seis grupos, abrange a Tanzânia, o Quênia, a Somália e Camarões;

- Zona H: com quatro grupos, abrange o Congo, a República Democrática do Congo e Angola;

- Zona J: com seis grupos, abrange a República Democrática do Congo, Ruanda, Burundi, Uganda, Quênia e Tanzânia;

- Zona K: com cinco grupos, abrange a República Democrática do Congo, Angola, Zâmbia e Namíbia; 
- Zona L: com seis grupos, abrange a República Democrática do Congo e a Zâmbia;

- Zona M: com seis grupos, abrange a República Democrática do Congo, Zâmbia, Zimbábue e Tanzânia;

- Zona N: com quatro grupos, abrange a Zâmbia, Botsuana, Moçambique, o Malaui e a Tanzânia;

- Zona P: com três grupos, abrange a Tanzânia, Moçambique e o Malaui;

- Zona R: com quatro grupos, abrange Angola, Namíbia e Botsuana;

- Zona S: com seis grupos, abrange o Zimbábue, Botsuana, Moçambique, A África do Sul, Suazilândia e Lesoto.

Greenberg (1955) classifica as línguas africanas em quatro famílias: a nigerokordofan, a nilo-saariana, a afroasiática e a koisan. Observa-se que as ideias de Greenberg são oriundas da classificação de Wistermann (1911 apud GREENBERG, 1955), que classificou as línguas sudanesas. Com sua reanálise, Greenberg (1955) considerou que a família nigerocongolesa se reparte em seis subdivisões. Dentre elas, encontra-se o benue-congo. Já a subfamília bantu não deveria ser uma subfamília coordenada a outras, mas um subgrupo do benue-congo. O kordofan, coordenado com a família nigero-congolesa, forma a nigerokordofan, uma família maior. A proposta de Greenberg (1955) pode ser vista no mapa linguístico da Figura 4: 


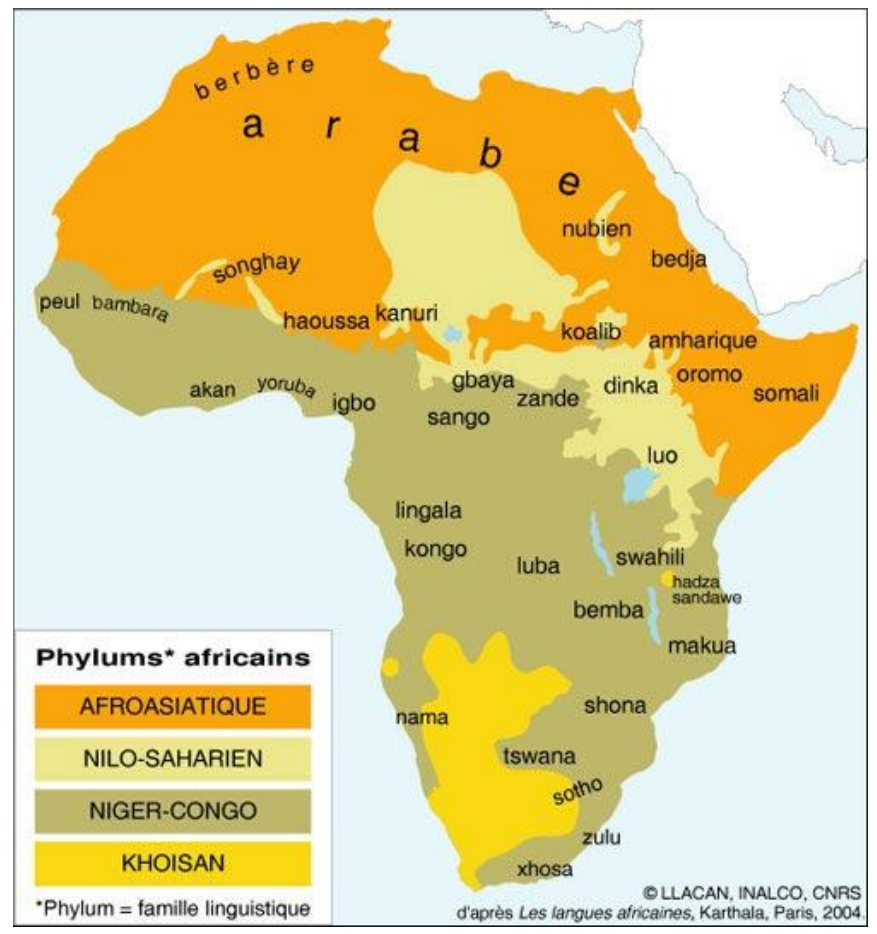

Figura 4: As famílias linguísticas africanas pela proposta inicial de Greenberg (1955)

É curioso observar que a população bantufone abrange hoje cerca de 60 milhões de falantes. O termo "bantu" foi usado inicialmente por W. Bleek (1862), considerado o fundador da linguística bantuísta. Bleek propôs a organização dos nomes bantu em 18 classes, descreveu as concordâncias e identificou os processos fonéticos como a assimilação, palatalização, harmonia vocálica, dentre outros.

Em 1899, Carl Meinhof ganhou também relevância na pesquisa linguística pela proposta de reconstruções preliminares do protobantu. Angenot e Amaral (2009) observam que quase todas as línguas da megafamília nigero-kordofan são tonais e que os cliques são evidenciados apenas no sul da área bantu devido aos empréstimos das línguas da família Koisan.

Greenberg (1955) considera que a subfamília bantu deve ser um grupo dentro da família nigero-congolesa devido às correspondências regulares identificadas entre o protobantu e o protossudanês ocidental e às semelhanças entre os sistemas de classificadores, o campo semântico e os morfemas lexicais compartilhados.

Ressalta-se que, para Greenberg (1955), o bantu não é diretamente ligado ao nigerocongolês, mas uma de suas subfamílias: 
Nigero-congolês $\rightarrow$ benue-kua $\rightarrow$ benue kongo $\rightarrow$ benue kongo leste $\rightarrow$ bantoide $\rightarrow$ bantoide sul $\rightarrow$ bantu

\subsection{As línguas africanas mais faladas pelos colaboradores do estudo}

Para a compreensão das interferências da L1 na aquisição do PB, nas subseções seguintes há uma breve descrição do sistema fonológico das línguas lingala, fon e ewondo, línguas mais faladas pelos colaboradores em contextos sociais e familiares. Convém apontar que o lingala e o ewondo são línguas bantu e que o fon pertence à subfamília nigerocongolesa cuá.

\subsubsection{As características do Lingala}

O lingala é uma língua franca ${ }^{8}$ falada por quase todos os grupos étnicos bantu em uma vasta região próxima do Rio Congo. Praticamente todos os falantes dessa língua também falam outras línguas em seus grupos. Guthrie (1970) aponta que há uma similaridade infindável entre o lingala e outras línguas bantu e, por isso, essa língua é usada muitas vezes para representar as demais. Foneticamente, essas línguas são idênticas e o lingala, particularmente, preservou muitas marcas de seu sistema fonético com o passar dos anos.

O lingala tem um sistema vocálico composto por sete vogais /i/, /e/, /ع/, /a/, /o/, /o/ e /u/. As vogais /e/ e / / / são bem distintas e devem ser escritas com grafemas diferentes para que haja distinção de palavras. Há uma regra de eufonia ${ }^{9}$ nessa língua em que vogais são abertas e fechadas para que nunca apareçam misturadas em um mesmo radical. Assim, /e/ é associada a /o/ mas nunca com / $/ /$ ou / /. O princípio da eufonia em outras línguas pode incluir prefixos e a classes de nomes, mas na língua lingala está unicamente associado às vogais fechadas, como em /mokolっ/ 'dia' e /esengo/ 'alegria'. As consoantes do lingala sob a análise de Guthrie (1970) podem ser vistas no Quadro 2:

\footnotetext{
${ }^{8}$ Por língua franca entende-se aquela que é falada por grupos de falantes de línguas maternas diferentes, mas que usam essa língua para um intercurso comum (GUIMARÃES, 2007).

${ }^{9}$ Princípio de alternância rítmica (Scarpa, 2014).
} 


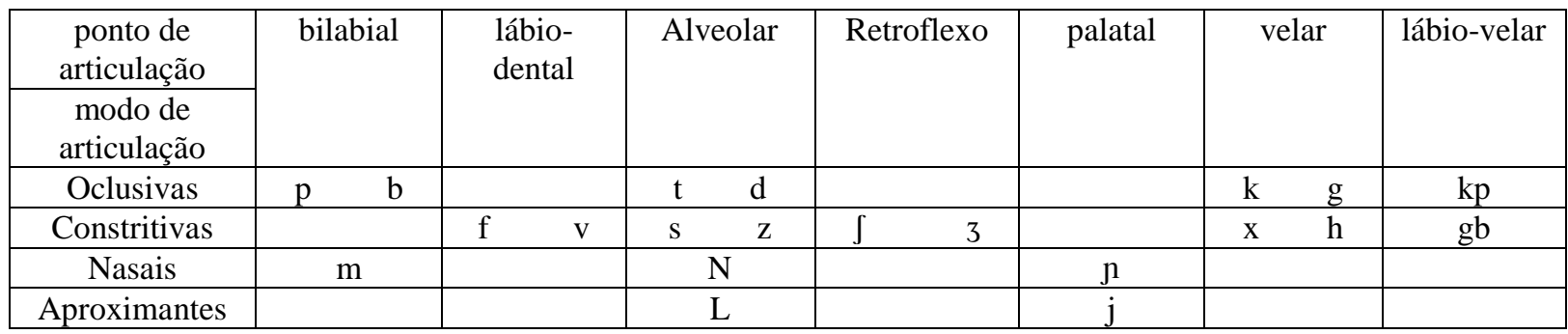

Quadro 2: Quadro consonantal do lingala por Guthrie (1970)

Sobre as consoantes, /b/, /d/ e /g/ e também /gb/ e /kp/, quando ocorrem, são frequentemente implosivas, mas não essencialmente. Ou seja, consoantes implosivas e explosivas vozeadas pertencem ao mesmo fonema.

\subsubsection{A entoação no lingala}

O lingala, como as demais línguas bantu, é uma língua tonal. Tanto o sistema tonal quanto o gramatical dessa língua sofreu inevitavelmente uma simplificação em sua adaptação enquanto língua franca. Entretanto, não se pode desconsiderar que a mudança faz parte da dinamicidade das línguas. O lingala tem tons semânticos e muitas palavras como nomes e verbos são definidos pela diferença entre os tons. Há também uma entoação gramatical, ou seja, cada flexão verbal tem seu próprio tom, embora não aparentem tons sintáticos.

Há apenas dois tipos de tom: alto e médio. O tom baixo nunca é usado e não afeta também as fronteiras de consoantes. Praticamente todas as fronteiras são formadas por raízes dissilábicas e todos os quadro padrões ocorrem. Guthrie (1970) aponta que os prefixos têm tom médio, embora algumas palavras tenham transferido prefixos de tom alto de outras línguas próximas.

Os verbos possuem quatro padrões de entoação que podem ser vistos na comparação com os nomes derivados da mesma raiz. Com exceção do subjuntivo, os prefixos pronominais são sempre de tom médio, até mesmo no plural.

Como em outras línguas, a forma final de questões interrogativas no lingala é distinta. Entretanto, é apenas a última sílaba que é afetada. Há uma distinção entre verbos e nomes nesse aspecto. A sílaba final de um verbo tem tom alto e não resistente, ou seja, ao 
invés de cair para o tom médio, o tom cai do médio para o baixo exatamente como se fosse de tom médio. Nos nomes, a sílaba final de tom alto cai para o médio e a final de tom médio cai ainda mais para o tom baixo.

Nos enunciados interrogativos, todos os enunciados que não envolvem palavras interrogativas possuem tons altos. Em enunciados afirmativos no modo indicativo, tons altos finais e tons médios permanecem no mesmo nível, tons crescentes permanecem crescentes. Em enunciados afirmativos no modo subjuntivo, as sílabas finais apresentam uma queda de tom no final das sílabas, distinguindo-os de comandos. A forma negativa é explicitada pelo aumento do nível da voz e pelo tom do advérbio té /te/, que sempre acompanha o fim de sentenças negativas. Os enunciados com esse advérbio são não resistentes, ou seja, caem do tom médio para o baixo. Em perguntas retóricas, o tom geralmente é alto. Guthrie (1970) ressalta que perguntas com pronomes interrogativos têm exatamente a mesma forma da entoação de outros enunciados do tipo: não é necessário haver um aumento de nível para mandar o tom final, pois a presença do pronome interrogativo já basta para a indicação de uma pergunta.

Outras características mostradas por Guthrie (1970) sobre o lingala são o alargamento ou estreitamento entre tons altos e normais, um aumento ou diminuição do tom da voz, que também pode ser gradual. Nessa língua, o aumento do tom de voz durante a enunciação é praticamente imperceptível, entretanto, há outra modificação que afeta a última silabada das sentenças ou palavras que se chama cadência final. Assim, Guthrie (1970) afirma que há quatro variações tonais no lingala: a normal, a variação de primeiro grau, a de segundo e a de terceiro.

Guthrie (1970) observou um aumento de tom de voz que também envolve um alargamento do intervalo entre dois tons. Essas quatro variações são bem marcadas. A variação normal é usada em todo discurso não enfático e é característica em enunciados simples, tanto afirmativos quanto negativos.

\subsubsection{As características da língua fon}

O quadro de vogais do fon apresenta 12 elementos, sete vogais orais e cinco nasais. São elas: /a/, / / /, /e/, /i/, /o/, / / / e /u/. /a/, / / /, /i/, / / e /u/ podem ser nasalisadas. Para que haja eufonia, as vogais que seguem consoantes nasais são também nasalisadas. Guillet (1972) 
intitula o fenômeno de economia linguística. São exemplos: mò /mon/ 'encontrar' e amà /aman/ 'folha'.

Quanto às consoantes, Guillet (1972, p. 9) apresenta o quadro abaixo:

\begin{tabular}{|c|c|c|c|c|c|c|c|}
\hline $\begin{array}{c}\text { ponto de } \\
\text { articulação } \\
\text { modo de } \\
\text { articulação }\end{array}$ & bilabial & $\begin{array}{l}\text { lábio- } \\
\text { dental }\end{array}$ & Alveolar & retroflexo & palatal & velar & lábio-velar \\
\hline oclusivas & $\mathrm{p} \quad \mathrm{b}$ & & $\mathrm{d}$ & & $\mathrm{c}$ & $\mathrm{K}$ & $\mathrm{Kp}$ \\
\hline constritivas & & $\mathrm{V}$ & $\mathrm{z}$ & & & $\mathrm{X}$ & $\mathrm{Gb}$ \\
\hline Nasais & $\mathrm{m}$ & & $\mathrm{N}$ & & $\mathrm{n}$ & & \\
\hline laterais & & & $\mathrm{L}$ & & & & \\
\hline $\begin{array}{c}\text { semi- } \\
\text { consoantes }\end{array}$ & & & & & $\mathrm{y}$ & & $\mathrm{W}$ \\
\hline
\end{tabular}

Quadro 3: Quadro consonantal do Fon de acordo com Guillet (1972)

A língua fon é uma língua tonal. Para distinguir os tons, há acentos na escrita. Guillet (1972) aponta que a língua possui quatro tons: um alto, um médio, um baixo e um modular descendente. Nesta língua é comum que haja duplicação ortográfica e alongamento fonológico de vogais, havendo dois tons simples, como em /átónn/ 'cinco' e /daá/ 'chefe de família'. É importante ressaltar também que o tom modular não pode ocorrer jamais entre consoantes surdas, ao contrário do tom alto, que é suportado apenas por essas consoantes. O tom médio pode ser suportado por todas as consoantes. $\mathrm{O}$ tom alto não é encontrado sobre as consoantes surdas e é invariável. É recorrente em vogais simples como /ó/ ou /é/. O tom baixo pode ser encontrado em sílabas com qualquer consoante, já o tom médio é mais raro em palavras monossilábicas e frequente naquelas com mais sílabas.

Como outras línguas, o fon tem muitos empréstimos linguísticos que também refletem na entoação da língua. Quando há um empréstimo, o acento se mantém na língua original, mas recebe um tom alto ou duplo, e, caso uma palavra termine com uma consoante formada apenas na língua original, o fon abre essa consoante e acrescenta a ela uma vogal. Pode-se observar em /cávi/ 'chave', de origem portuguesa e também em /sóza/, de origem inglesa, soldier, 'soldado'.

Guillet (1972) afirma que as palavras no fon têm um tom próprio e é indispensável conhecê-lo. O tom pode variar de acordo com sua origem (referência aos empréstimos de outras línguas, como visto acima), ou ainda ser alto, baixo, modular ou médio.

Outra noção importante apresentada por Guillet (1972) é a da unidade tonal. A unidade tonal é determinante para a tonalidade e aborda como essas unidades são percebidas como pausas reais ou virtuais da voz. Essas unidades justapostas formam as frases. Com o 
objetivo de determinar os grupos de palavras que formam as unidades tonais, Guillet aponta que há uma regra interior para as unidades tonais. É certo que as palavras possuem um tom próprio, entretanto, ele pode se modificar devido às condições do contexto. Então, se as palavras se encontram mais frequentemente juntas e podem ter seus tons modificados, pode-se dizer que houve uma unidade tonal. É o lugar da palavra na unidade tonal que determina o tom que ela terá. Como exemplo, Guillet (1972) indica que a sílaba que termina em unidade tonal e em tom baixo, permanece em tom baixo. Como em: é nùl sìn 'ele bebeu água'. Em nú termina a primeira unidade tonal e no substantivo sin, na segunda.

\subsubsection{A fonologia da língua ewondo}

Também pertencente à subfamília bantu, o ewondo tem 33 fonemas, os quais Redden (1979) dividiu entre 27 segmentais e seis suprassegmentais. Quanto aos segmentais, há 20 consoantes e sete vogais. Os fonemas suprassegmentais indicam a caracterização tonal da língua: três tons e três junturas. O quadro consonantal, descrito por Redden (1979, p. 5), está disponível abaixo:

\begin{tabular}{|c|c|c|c|c|c|}
\hline & labiais & alveolares & palatais & velares & lábio- \\
\hline oclusivas & b & $\begin{array}{ll}\mathrm{t} & \mathrm{ts} \\
\mathrm{d} & \mathrm{dz} \\
\end{array}$ & & $\begin{array}{l}\mathrm{k} \\
\mathrm{g}\end{array}$ & $\begin{array}{l}\mathrm{kp} \\
\mathrm{gb}\end{array}$ \\
\hline fricativas & $\begin{array}{l}\mathrm{f} \\
\mathrm{v}\end{array}$ & $\begin{array}{l}\mathrm{S} \\
\mathrm{Z}\end{array}$ & & & \\
\hline nasais & $\mathrm{m}$ & $\mathrm{N}$ & $\mathrm{n}$ & $\eta$ & \\
\hline laterais & & $\mathrm{L}$ & & & \\
\hline semivogais & w & & $\mathrm{y}$ & & \\
\hline
\end{tabular}

Quadro 4: Quadro consonantal da Língua Ewondo segundo Redden (1979)

Redden (1979) observa que as consoantes oclusivas possuem alofones que podem ser fricativos ou tepes, em algumas posições não iniciais de morfemas. Outra característica é que a oposição entre consoantes sonoras e surdas ocorre em fricativas e oclusivas, mas não ocorre entre /b/ e /p/, pois /p/ só ocorre em variantes expandidas da língua ewondo ou em empréstimos linguísticos para situações muito específicas.

As vogais da língua ewondo podem ser altas, médias e baixas, havendo um contraste entre anteriores e posteriores nesses três níveis, mas o contraste entre anteriores, centrais e 
posteriores só ocorre em dois desses níveis. Redden (1979) aponta que a duração das vogais nessa língua é fonêmica, havendo uma quantidade significativa de encontros vocálicos e também alongamentos. São vogais da língua ewondo: /i/, /u/, /e/, /ə/, /o/, /ع/, /a/, e /১/.

Como língua tonal, o ewondo apresenta três tons: alto, médio e baixo. O tom baixo só é marcado na ocorrência de nasais assilábicas, para que haja uma distinção entre estas e encontros vocálicos seguidos de consoantes nasais. Redden (1979) indica que os tons no ewondo são relativos por não apresentarem distâncias constantes. Na entoação, após um tom baixo, um tom alto pode ser produzido, mas de maneira menos marcada. Os tons médios são mais frequentes depois de altos ou baixos e depois dos baixos, há duas opções para o falante: permanecer no mesmo nível entoacional ou seguir para um nível mais alto. Todas as sílabas no ewondo têm obrigatoriamente um tom. Os tons silábicos podem seguir para outros níveis linguísticos: morfemas e palavras, provendo, inclusive, tons gramaticais.

Os três fonemas de juntura marcam fronteiras silábicas. Na língua ewondo, os tipos silábicos podem ser $\mathrm{V}, \mathrm{CV}, \mathrm{CVC}, \mathrm{CCV}$ e CCVC. V, nessa classificação, abrange as consoantes assilábicas.

\subsection{Características segmentais e autossegmentais das línguas nigero-congolesas}

As línguas da família nigero-congolesa, com suas propriedades tonais, têm sinto um trampolim para o desenvolvimento da fonologia autossegmental e há muito ainda o que ser feito. Linguistas como Hyman (1982), Kisseberth (1984) e Goldsmith (1984), por exemplo, discutiram o acento nessas línguas e outros como Meeussen (1965) propuseram uma análise tonal. Entretanto, há também discussões sobre a existência tanto de padrões tonais quanto acentuais nessas línguas que buscam compreender como os contrastes de pitch devem ser tratados e explorados.

Várias questões têm sido levantadas na análise das línguas da região leste-central da África. Os estudos mais recentes trazem discussões acerca da natureza fonológica das representações e das relações geométricas entre níveis não lineares de representação, modo e domínios de aplicação de regras. Estudiosos como Odden (1987) e Goldsmith (1987) afirmam

que não há contrastes léxicos envolvendo altura $(\mathrm{H}$ e L) na maioria das línguas, principalmente no sistema verbal. Essa afirmação levou à ideia de que apenas tons altos $(\mathrm{H})$ 
devem ser especificados lexicalmente. Os tons baixos (L) são amplamente substituídos pela omissão de regras, a não ser que uma língua exija o contrário.

Outra questão é a de que a atribuição tonal (Goldsmisht, 1984), especificamente de tons altos, é muito previsível uma vez que esta é alcançada pelas regras gerais das línguas afetadas. Dessa forma, essas regras são dependentes do tempo e do aspecto morfológico do sistema verbal.

Odden (1995) afirma que as línguas bantu, em especial, possuem características de grande relevância para a fonologia, principalmente, pelos tons e duração das vogais e por serem parte das raras línguas com ausência de regras frasais com amplo contraste entre tom e a duração de sons vocálicos. Em praticamente todas as línguas bantu, há regras entre as palavras que são sensíveis às propriedades morfolexicais. Pela ausência de regras frasais, as línguas bantu trouxeram grandes contribuições à Linguística por apresentarem claros exemplos de como a sintaxe influencia a fonologia.

A fonologia segmental das línguas bantu pode ser caracterizada de acordo com suas variações. Apesar de um grande número de línguas espalhadas em um grande espaço geográfico, os estudos recentes se concentram apenas na estrutura silábica dessas línguas, em seus inventários de vogais e consoantes e nos relevantes processos fonológicos. $\mathrm{O}$ compartilhamento desses estudos evidencia as grandes diferenças e similaridades para a compreensão da fonologia nigero-congolesa em geral.

Sobre as características fonológicas dessss línguas, Guthrie (1948) aponta que nessa família linguística há diferentes tipos de junções de sílabas. Dentre as principais características da família, estão a duração das vogais, os tons altos e consecutivos, os sons indeterminados e os padrões tonais.

Sobre o padrão das vogais, há dois tipos de duração identificáveis na pronúncia: uma curta e uma longa. Segundo Guthrie (1948), não é possível encontrar vogais alongadas no final de palavras na fala usual, sendo comum encontrá-las em quase todas as outras posições. O uso de vogais alongadas acarreta grandes mudanças de significado nas fronteiras de sílabas, especialmente quando há vogais em fronteiras de sílabas.

Para integrar a discussão sobre os aspectos fonológicos das línguas bantu, é de suma importância tratar das características prosódicas dessas línguas. Como citado anteriormente, há um número considerável de línguas tonais na subsubfamília bantu que fazem distinção entre tom alto e tom baixo, combinados muitas vezes à queda de contornos. 
Maddieson (2003) considera que os trabalhos feitos sobre a prosódia de línguas nigero-congolesas são negligenciados se comparados à fonética segmental. A afirmação se dá pelo fato de que os estudos para tratamentos prosódicos têm ganhado mais suporte e foco apenas na atualidade. 


\section{METODOLOGIA}

Este capítulo apresenta a metodologia usada para a elaboração desta pesquisa, explicitando suas ferramentas de análise e o perfil dos colaboradores.

\subsection{O contexto e os participantes da pesquisa}

A capital federal é um campo fértil para o ensino e aprendizagem do português. Existem os integrantes do corpo diplomático, estrangeiros que têm visto permanente por motivos de trabalho, alunos de intercâmbio, dentre outros. Durante os anos de 2011, 2012 e 2013, a Universidade de Brasília recebeu grupos de francófonos vindos do Congo, Benim e República Democrática do Congo e Togo pelo programa PEC-G. A universidade recebeu, em média, 14 estudantes por ano durante esse triênio. Esses francófonos vêm para o Brasil para cursar graduação ou pós e, para isso, precisam obter nota mínima, equivalente ao nível intermediário, no exame oficial de proficiência do Português Brasileiro, o Celpe-Bras. Cada grupo passa, em média, 7 meses imerso e aprendendo o português formalmente no curso de português para estrangeiros da universidade.

Durante 2011 e 2012 e uma pequena parte de 2013, enquanto professora do PEC na Universidade de Brasília, a pesquisadora observou as dificuldades fonéticas e fonológicas no processo de aquisição/aprendizagem do Português Brasileiro para esses aprendizes. Essas dificuldades podem ser agentes impeditivos na parte oral do exame Celpe-Bras, uma vez que o exame também avalia criteriosamente a pronúncia dos examinandos, como visto na imagem abaixo, relacionada ao papel do avaliador oral no segundo exame de 2012:

\begin{tabular}{|c|c|c|c|c|c|c|}
\hline 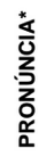 & $\begin{array}{l}\text { Pronúncia (sons, ritmo } \\
\text { e entonação) } \\
\text { adequada. }\end{array}$ & $\begin{array}{l}\text { Pronúncia (sons, ritmo } \\
\text { e entonação) com } \\
\text { algumas } \\
\text { inadequações e/ou } \\
\text { interferências de } \\
\text { outras línguas. }\end{array}$ & $\begin{array}{l}\text { Pronúncia (sons, ritmo e } \\
\text { entonação) com } \\
\text { inadequações e/ou } \\
\text { interferências de outras } \\
\text { linguas. }\end{array}$ & $\begin{array}{l}\text { Pronúncia (sons, ritmo e } \\
\text { entonação) com } \\
\text { inadequações e/ou } \\
\text { interferências } \\
\text { frequentes de outras } \\
\text { línguas. }\end{array}$ & $\begin{array}{l}\text { Pronúncia (sons, ritmo } \\
\text { e entonação) } \\
\text { inadequada e/ou } \\
\text { interferências } \\
\text { acentuadas de outras } \\
\text { línguas. }\end{array}$ & $\begin{array}{l}\text { Pronúncia (sons, ritmo e } \\
\text { entonação) inadequada } \\
\text { e/ou interferências } \\
\text { muito acentuadas de } \\
\text { outras línguas. }\end{array}$ \\
\hline
\end{tabular}

Figura 5: Recorte do campo de avaliação Pronúncia, da ficha do avaliador oral do exame Celpe-Bras $\left(2^{\circ} / 2012\right)$ 
Dessa maneira, para a análise das interferências linguísticas desses sujeitos, foram convidados dois colaboradores de cada ano do triênio em questão. Como muitos sujeitos que passam pelo programa PEC vão para outras universidades brasileiras, foram convidados aqueles que escolheram a Universidade de Brasília para o prosseguimento de seus estudos acadêmicos. Não houve preferência quanto ao gênero do colaborador.

Os colaboradores da pesquisa responderam a uma ficha de identificação (Apêndice B) que não teve a intenção de selecionar sujeitos com características específicas, mas sim identificar características linguísticas que fossem relevantes na análise dos dados. As informações coletadas quanto ao perfil dos colaboradores estão disponíveis na tabela abaixo:

\begin{tabular}{|c|c|c|c|c|c|}
\hline Colaborador & Gênero/Idade & $\begin{array}{l}\text { País de } \\
\text { origem }\end{array}$ & $\begin{array}{c}\text { Tempo de } \\
\text { imersão (em } \\
\text { janeiro de } \\
\text { 2015) }\end{array}$ & $\begin{array}{l}\text { Línguas que } \\
\text { fala }\end{array}$ & $\begin{array}{c}\text { Língua de } \\
\text { escolarização }\end{array}$ \\
\hline $\mathrm{C} 1$ & $\mathrm{M} / 25$ & $\begin{array}{c}\text { República } \\
\text { Democrática } \\
\text { do Congo }\end{array}$ & $\begin{array}{c}3 \text { anos e } 10 \\
\text { meses }\end{array}$ & $\begin{array}{c}\text { francês, } \\
\text { kibindji, } \\
\text { lingala, e } \\
\text { tshiluba }\end{array}$ & francês \\
\hline $\mathrm{C} 2$ & $\mathrm{M} / 25$ & $\begin{array}{c}\text { República } \\
\text { Democrática } \\
\text { do Congo }\end{array}$ & $\begin{array}{c}1 \text { ano e } 10 \\
\text { meses }\end{array}$ & $\begin{array}{l}\text { francês, } \\
\text { kiboma, } \\
\text { kikongo e } \\
\text { lingala }\end{array}$ & francês \\
\hline $\mathrm{C} 3^{10}$ & $F / 20$ & Camarões & $\begin{array}{c}1 \text { ano e } 10 \\
\text { meses }\end{array}$ & $\begin{array}{l}\text { ewondo, } \\
\text { francês e } \\
\text { inglês }\end{array}$ & francês e inglês \\
\hline $\mathrm{C} 4$ & $\mathrm{M} / 25$ & Benim & $\begin{array}{c}2 \text { anos e } 10 \\
\text { meses }\end{array}$ & $\begin{array}{l}\text { fon, francês e } \\
\text { goun }\end{array}$ & francês \\
\hline $\mathrm{C} 5$ & $\mathrm{M} / 22$ & $\begin{array}{c}\text { República } \\
\text { Democrática } \\
\text { do Congo }\end{array}$ & $\begin{array}{c}2 \text { anos e } 10 \\
\text { meses }\end{array}$ & $\begin{array}{c}\text { francês, } \\
\text { kikongo e } \\
\text { lingala }\end{array}$ & francês \\
\hline C6 & $\mathrm{M} / 25$ & $\begin{array}{c}\text { República } \\
\text { Democrática } \\
\text { do Congo }\end{array}$ & $\begin{array}{c}3 \text { anos e } 10 \\
\text { meses }\end{array}$ & $\begin{array}{c}\text { francês, } \\
\text { kikongo, } \\
\text { lingala, luba e } \\
\text { swahili }\end{array}$ & francês \\
\hline C0 (Controle) & $\mathrm{M} / 27$ & Brasil & Falante & PB e inglês & \\
\hline
\end{tabular}

${ }^{10}$ Não houve preferências quanto ao gênero para a coleta de dados, entretanto, C3 é a única colaboradora do sexo feminino. É importante ressaltar que, sob os parâmetros acústicos, a voz feminina apresenta frequência mais elevada em comparação à masculina. 


\begin{tabular}{|l|l|l|l|l|l|}
\hline & & & nativo & & português \\
\hline
\end{tabular}

Quadro 5: Perfil dos colaboradores da pesquisa

Com o questionário, foi possível coletar informações sobre as línguas maternas dos aprendizes, se eles tinham conhecimento de outras línguas, idade, língua de escolarização e período de imersão no Português Brasileiro, informações necessárias para o esboço dos perfis sociolinguísticos.

Os questionários aplicados mostraram que os seis sujeitos de pesquisa eram africanos de nacionalidade beninense, congolesa (da República Democrática do Congo) e camaronesa. Para todos, o francês era a segunda língua, aquela aprendida formalmente na escola. Cinco desses sujeitos eram homens e uma, mulher. A faixa etária dos sujeitos de pesquisa foi de 19 a 25 anos. Como a maioria dos colaboradores integrou gênero masculino, o colaborador controle também foi de gênero masculino e tinha, no momento da coleta, 27 anos.

Para melhor entendimento dos dados, os dados dos colaboradores foram agrupados por tempo de imersão no PB, com exceção do colaborador controle:

\begin{tabular}{|c|c|c|}
\hline Colaborador & $\begin{array}{l}\text { Tempo de imersão (em janeiro } \\
\text { de 2015) }\end{array}$ & Grupo de análise \\
\hline $\mathrm{C} 1$ & 3 anos e 10 meses & \multirow{2}{*}{ A } \\
\hline C6 & 3 anos e 10 meses & \\
\hline $\mathrm{C} 4$ & 2 anos e 10 meses & \multirow{2}{*}{ B } \\
\hline $\mathrm{C} 5$ & 2 anos e 10 meses & \\
\hline $\mathrm{C} 2$ & 1 ano e 10 meses & \multirow{2}{*}{$\mathrm{C}$} \\
\hline $\mathrm{C} 3$ & 1 ano e 10 meses & \\
\hline
\end{tabular}

Quadro 6: Colaboradores agrupados por tempo de imersão

Os sujeitos desta pesquisa permitiram a coleta e o estudo dos dados originados das gravações realizadas por meio de um Termo de Consentimento Livre e Esclarecido (TCLE), Apêndice A desta pesquisa. 


\subsection{Os procedimentos da coleta de dados}

A coleta de dados deste trabalho e seu projeto de pesquisa pautaram-se nas exigências do Comitê de Ética em Pesquisa do Instituto de Ciências Humanas da Universidade de Brasília e do Ministério da Saúde (Plataforma Brasil). O parecer está no Anexo A. A seleção do corpus desta pesquisa foi baseada em gravações de leituras de enunciados, palavras isoladas e contação de mini-histórias. Não foram consideradas influências pragmáticas e emocionais dos sujeitos de pesquisa.

Dentre os dados coletados, foram selecionados apenas os enunciados lidos de maneira não espontânea para que fosse possível contrastar criteriosamente as produções dos colaboradores. Vale ressaltar que a escolha da estratégia de leitura de enunciados contribui para a organização de padrões, mas não considera a criatividade do falante no emprego das mesmas estruturas com diferentes entonações com o objetivo de abranger atos de fala. $\mathrm{O}$ material usado pelos colaboradores para a leitura de enunciados pode ser encontrado no Apêndice $\mathrm{C}$ desta tese. Compuseram os dados selecionados para a análise desta pesquisa:

- Enunciados declarativos afirmativos;

- Enunciados declarativos negativos;

- Enunciados injuntivos;

- Enunciados interrogativos.

Ao todo, foram realizadas duas coletas para a obtenção dos dados. O acervo de dados conta com 315 enunciados e 14 narrações de mini-histórias motivadas por animações em vídeo. Há enunciados em português brasileiro, em francês e na língua mais usada pelo colaborador com sua família. Para o presente estudo, apenas os enunciados em PB foram analisados. Os demais dados constituíram um corpus que tem utilidade para pesquisas futuras.

\subsection{As gravações}


O uso de equipamentos para gravação torna a documentação de dados independente das perspectivas do pesquisador e dos sujeitos em estudo. Flick (1995, p. 266) observa que “após informar aos participantes sobre a finalidade da gravação, a expectativa do pesquisador é de que eles simplesmente esqueçam a presença do gravador e que a conversa corra naturalmente".

Embora não tenha havido uma conversa para que o colaborador desenvolvesse suas ideias na oralidade naturalmente, todos os colaboradores foram instruídos a lerem os enunciados da forma mais natural possível, sem a preocupação de monitorar suas falas. Flick (1995) aponta ainda que o uso de equipamentos mais discretos pode facilitar uma gravação mais naturalista e que o pesquisador deve limitar-se a gravar apenas o que for necessário para a pesquisa.

Para a gravação dos dados, utilizou-se a placa Fast Track Pro da M-Audio com o microfone B-2 Pro da Behringer. O microfone foi conectado à placa e, posteriormente, a placa, ao laptop. Como as gravações requeriam edições, por serem feitas em fluxo contínuo, usou-se o programa Sony SoundForge Audio Studio (Versão 10) para suas fragmentações. As gravações foram feitas individualmente em ambiente com isolamento acústico na Biblioteca Central da Universidade de Brasília, buscando diminuir efeitos de interferência nas gravações. Todos os sujeitos de pesquisa foram instruídos por textos orais e escritos sobre as gravações. Caso o sujeito de pesquisa quisesse questionar sobre os materiais cedidos como elementos provocadores, foi permitido que houvesse discussões.

\subsection{Procedimentos de análise de dados}

Para as análises dos dados, utilizou-se programa PRAAT, versão 5.4.04, (BOERSMA e WEENINK, 2014). O programa gera espectrogramas de banda larga, sincronizados em forma de onda no computador para a observação dos limites de unidades fonéticas.

\subsubsection{A segmentação das unidades VV e o cálculo de $z$-score}


Foi medida a duração das unidades, do tamanho da sílaba, que apresentam ligação direta com o ritmo. Para isso, o enunciado foi segmentado manualmente em unidades VogalVogal (VV) para promover a comparação entre os dados do colaborador controle e dos aprendizes do PB, separados por períodos de imersão, línguas maternas e modalidades. Barbosa (2006) indica a unidade VV como uma sílaba fonética entre o segmento acústico que vai do onset de uma vogal até o onset da vogal seguinte. Para a transcrição e rotulação das unidades, não foi possível utilizar os símbolos do IPA, pois não são adequados ao script SG Detector, que requer uma transcrição de cunho fonológico e mais larga. A Figura 6 mostra um exemplo de segmentação de enunciado em unidade VV, "ela não me respeita”, produzido pelo colaborador $\mathrm{C} 2$.

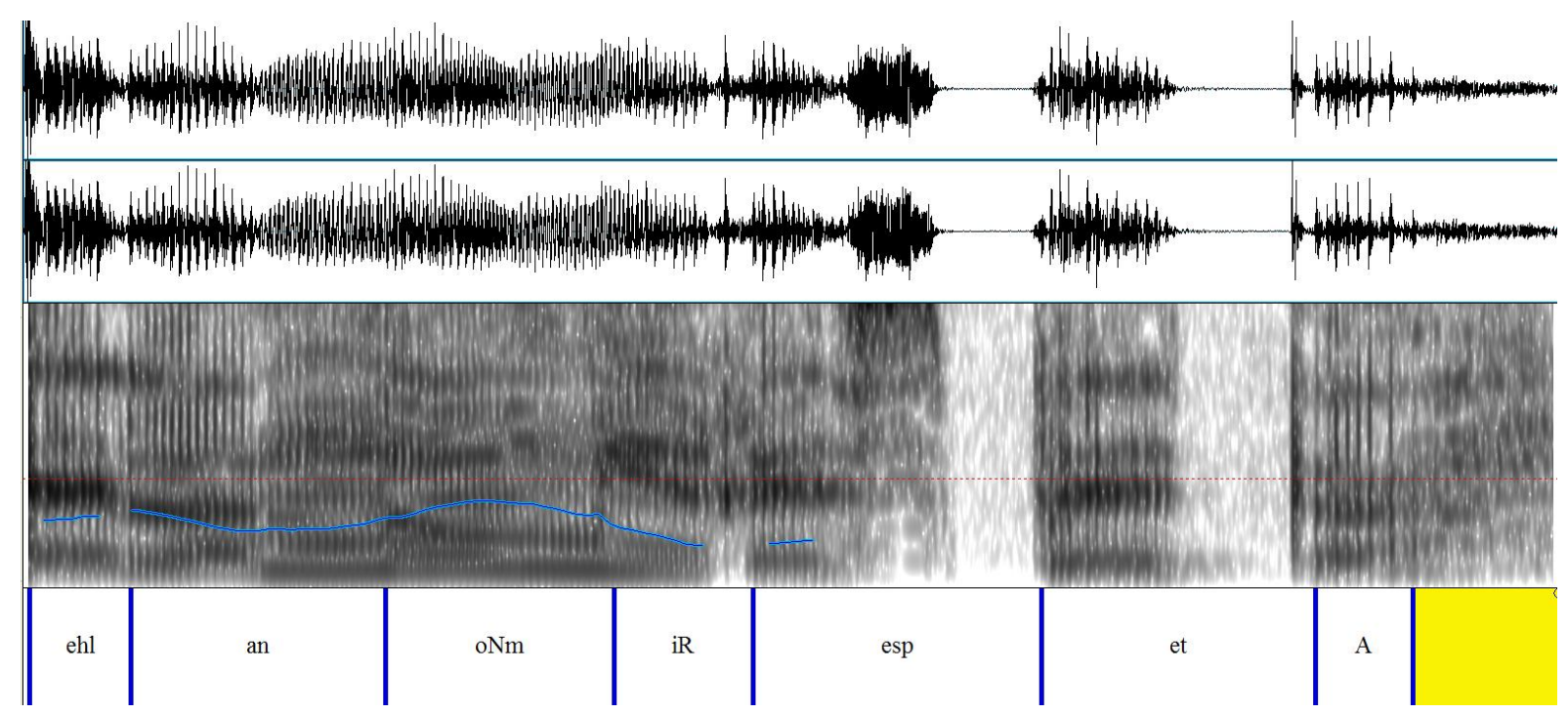

Figura 6: Exemplo de segmentação de enunciado em unidades VV no enunciado "Ela não me respeita", produzido por $\mathrm{C} 1$.

Barbosa (2006) aponta que a duração normalizada das unidades VV são características acústico-prosódicas do acento frasal e que, portanto, essas unidades podem ser consideradas como unidades mínimas para o processamento do ritmo da fala. Para fazer a extração dessa medida, considerando o cálculo da duração normalizada das unidades VV, utilizou-se o script SG Detector, desenvolvido por Barbosa (2009, p. 459). O script calcula o valor de z-score e o z-score suavizado da duração das unidades VV ao longo do enunciado, gerando uma segmentação dos grupos frasais dos enunciados. A segmentação é feita através do cálculo do desvio-padrão das médias de duração das unidades VV, que são normalizadas pelo cálculo de z-score. $\mathrm{O}$ valor de $z$-score indica o afastamento do valor medido em relação a uma média, em unidades de desvio-padrão. Já os valores de z-score suavizado permitem 
“atenuar variações locais de duração advindas da queda de duração em unidades VV póstônicas e/ou duração de fones muito distintos da relação de durações dos fones do PB" (Barbosa, 2006, p. 170).

\subsubsection{Os testes estatísticos usados para a validação dos dados}

Para a análise estatística dos dados, foi adotado o teste ANOVA (Analysis of Variance), um teste paramétrico amplamente utilizado que faz uma comparação de médias através da variância. Por ser um teste paramétrico, supõe-se $\varepsilon_{i j} \sim N\left(0, \sigma^{2}\right)$. Dessa forma, os erros para cada observação apresentam uma distribuição normal com média zero e variância constante.

Para a utilização da técnica da ANOVA os dados foram dispostos da seguinte maneira:

\begin{tabular}{lcrr}
\multicolumn{1}{c}{ Segmentos Acústicos } & \multicolumn{1}{c}{$\begin{array}{c}\text { Duração } \\
(\mathrm{ms})\end{array}$} & \multicolumn{1}{c}{$\begin{array}{c}\text { Z-score } \\
(\mathrm{c} 0)\end{array}$} & $\begin{array}{c}\text { Zsuav. } \\
(\mathrm{c} 0)\end{array}$ \\
\hline $\mathrm{aR}$ & 131 & $-0,67$ & $-1,34$ \\
\hline $\mathrm{Um}$ & 113 & $-2,67$ & -2 \\
\hline $\mathrm{As}$ & 130 & $-0,88$ & $-1,53$ \\
\hline $\mathrm{eUk}$ & 161 & $-1,91$ & $-1,28$ \\
\hline $\mathrm{UaRt}$ & 236 & $-1,03$ & $-0,63$ \\
\hline $\mathrm{Um}$ & 134 & 1,31 & $-0,11$ \\
\hline $\mathrm{Em}$ & 151 & $-0,39$ & $-0,4$ \\
\hline $\mathrm{In}$ & 93 & $-1,77$ & $-1,3$ \\
\hline $\mathrm{A}$ & 47 & $-0,8$ & $-1,12$
\end{tabular}

Tabela 1: Valores de duração, z-score, z-score suavizado e fronteiras para cada unidade VV do enunciado "Arruma seu quarto, menina", produzido por $\mathrm{C} 0$.

Depois de organizados como na Tabela 1, os dados foram adequados à tabela requerida para a realização da estatística baseada no teste ANOVA.

\begin{tabular}{lcccc}
\hline Fonte de Variação & $\begin{array}{c}\text { Soma de } \\
\text { Quadrados }\end{array}$ & $\begin{array}{c}\text { Graus de } \\
\text { Liberdade }\end{array}$ & $\begin{array}{c}\text { Quadrados } \\
\text { Médios }\end{array}$ & Teste F \\
\cline { 4 - 5 }
\end{tabular}




\begin{tabular}{cccc}
\hline Entre Grupos & $Q_{e}$ & $k-1$ & $S_{e}^{2}=\frac{Q_{e}}{k-1}$ \\
\hline $\begin{array}{c}\text { Dentro dos } \\
\text { Grupos }\end{array}$ & $Q_{r}=Q_{t}-Q_{e}$ & $n-k$ & $S_{r}^{2}=\frac{Q_{t}-Q_{e}}{n-k}$ \\
\hline Total & $Q_{t}$ & $n-1$ & \\
\hline
\end{tabular}

Tabela 2: Tabela-padrão para a aplicação do teste ANOVA (Analysis of Variance)

Para obter os valores da tabela, obtém-se os valores das variáveis pelas equações cálculos estatísticos abaixo:

$$
Q_{e}=\sum_{i}\left[\frac{\left(\sum_{j} x_{i j}\right)^{2}}{n_{i}}\right]-C \quad Q_{t}=\sum_{i=1}^{K} \sum_{j=1}^{n_{i}} x_{i j}^{2}-C \quad C=\frac{\left(\sum_{i=1}^{K} \sum_{j=1}^{n_{i}} x_{i j}\right)^{2}}{n}
$$

Dessa forma, se $F_{c a l}>F_{(k-1, n-k)}$, conclui-se pela hipótese nula, ou seja, a igualdade entre os grupos, caso contrario concluímos pela hipótese alternativa $\left(H_{1}\right)$. Os valores de $\mathrm{F}$ foram obtidos pelo procedimento de Fisher, que realiza testes $t$ múltiplos.

Outra técnica estatística utilizada foi o Intervalo de Confiança (IC) para média, em que é possível saber quanto a média pode variar em certa probabilidade de confiança. A técnica pode ser escrita como:

$$
P\left(\bar{x}-Z_{\alpha / 2} \frac{\sigma}{\sqrt{n}} \leq \mu \leq \bar{x}+Z_{\alpha / 2} \frac{\sigma}{\sqrt{n}}\right)=1-\alpha
$$

Em que $\bar{x}$ é a média amostral, ${ }^{\frac{\alpha}{2}}$, o percentual da distribuição normal e $\sigma$ a variância amostral.

Ressalta-se que o resultado de cada comparação possui uma estatística chamada de p-valor. Essa estatística ajuda a concluir sobre o teste realizado. Caso esse valor seja maior que o nível de significância adotado (erro ou $\alpha$ ), conclui-se, portanto, que a $H_{0}$ (a hipótese nula) é a hipótese verdadeira, caso contrário opta-se por $H_{1}$, a hipótese alternativa.

Após realizar a análise estatística dos dados provenientes da segmentação de todos os enunciados, os valores gerados pelo script SG Detector proporcionaram a criação de gráficos comparativos entre os colaboradores. Como é possível notar na Figura 7, em que o mesmo enunciado é comparado de acordo com as produções de C2 e C0. 


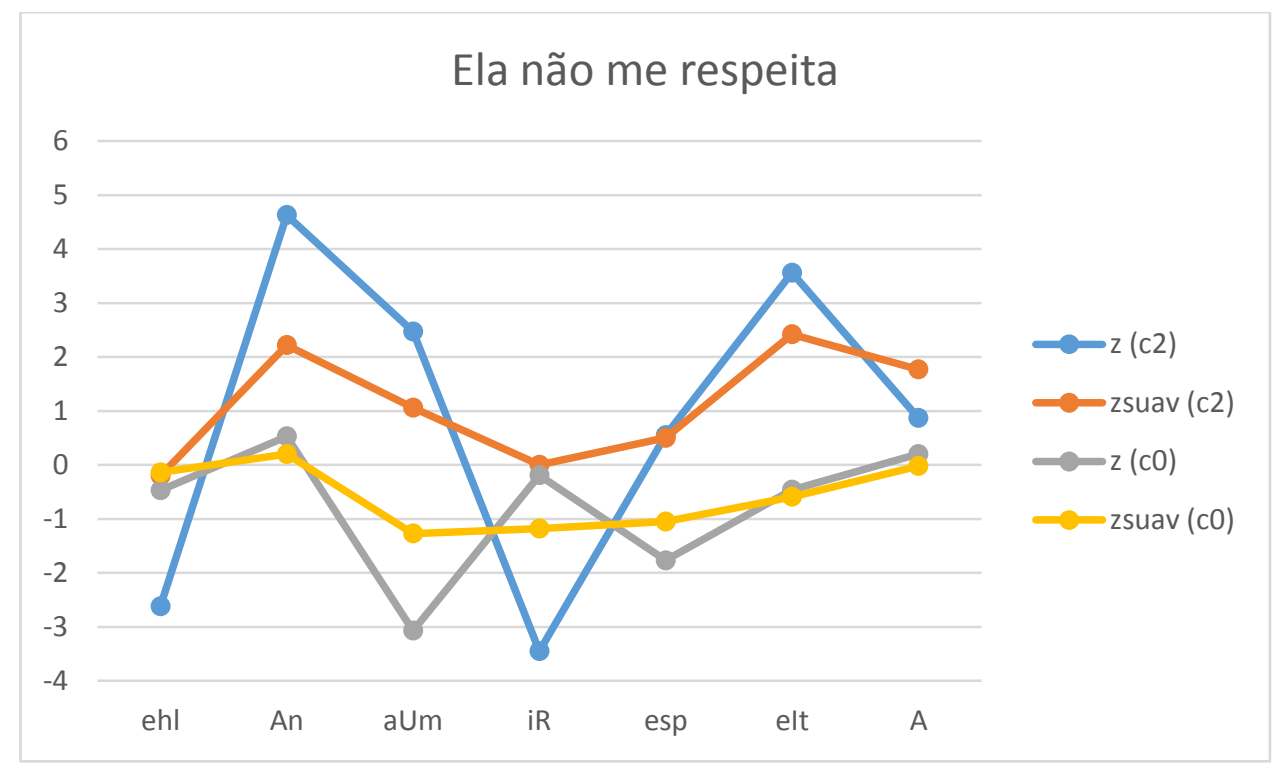

Figura 7: Valores de z-score e z-score suavizado de C0 e C2 no enunciado "Ela não me respeita".

Conforme evidenciado pelas cores do gráfico, as linhas de z (z-score) de C2 e C0 apresentam mais picos que as linhas de zsuav (z-score suavizado). Com o cálculo da suavização (Barbosa, 2006), os picos destacados são aqueles que têm mais chances de serem percebidos de forma auditiva. Para Barbosa (2006), a suavização atenua os efeitos da duração de cada fone e do número de fones em cada unidade $\mathrm{VV}$, assim, os aspectos prosódicos são mais ressaltados.

\subsubsection{A variação da frequência fundamental}

A variação da frequência fundamental pode implicar diferenças de entoação entre falantes nativos e aprendizes de segunda língua e, por esse motivo, o cálculo de seus valores apresenta dados significativos para esta tese. Foram medidos os valores máximos, mínimos e de variação de f0 em cada enunciado e, posteriormente, os dados foram comparados àqueles do colaborador controle. Foram avaliadas as médias dos valores de variação de f0 (f0 range), como exemplificado na Tabela 2. 


\begin{tabular}{c|c|c|c}
$\begin{array}{c}\text { Unidade } \\
\text { VV }\end{array}$ & f0 mín. & f0 máx. & f0 range \\
\hline Ak & 151 & 130 & 21 \\
\hline $\mathrm{E}$ & 170 & 119 & 51 \\
\hline \multicolumn{4}{c}{$\mathrm{C} 1$ - Será que vai chover? } \\
\hline $\begin{array}{c}\text { Unidade } \\
\text { VV }\end{array}$ & f0 mín. & f0 máx. & f0 range \\
\hline Ak & 157 & 138 & 19 \\
\hline eR & 143 & 121 & 22
\end{tabular}

Tabela 3: Variação de f0 range no enunciado "Será que vai chover?", produzido por $\mathrm{C} 0$.

\subsubsection{A notação entoacional}

Para a análise da curva melódica dos enunciados produzidos pelos colaboradores, utilizou-se o sistema de notação DaTo (Dynamic Tones of Brazilian Portuguese), proposto por Lucente (2007, 2008 e 2012). A notação, em sua forma completa, é composta por seis camadas, sendo três delas fixas (LUCENTE, 2012): i) contornos dinâmicos, ii) segmentação semiautomática da fala em unidades VV e iii) transcrição ortográfica. As demais camadas podem ser adaptadas ou omitidas, de acordo com o objetivo de cada notação, são elas: iv) detecção automática de pausas/grupos acentuais, v) informação pragmática e vi) segmentação em unidades discursivas.

Para esta tese, foram utilizadas as três camadas essenciais da notação DaTo (contornos dinâmicos, segmentação da fala em unidades VV e transcrição ortográfica), além da camada para a segmentação silábica, SIL na Figura 8, e para grupos acentuais, StressGroups, na mesma figura.

O sistema DaTo apresenta uma notação para a descrição da entoação do PB baseada em um modelo dinâmico e funcional. Os contornos, movimentos contínuos de f0, são intitulados de ascendentes ou descendentes e indicam movimentos pelas letras $\mathrm{H}$ (high) e L (low). 


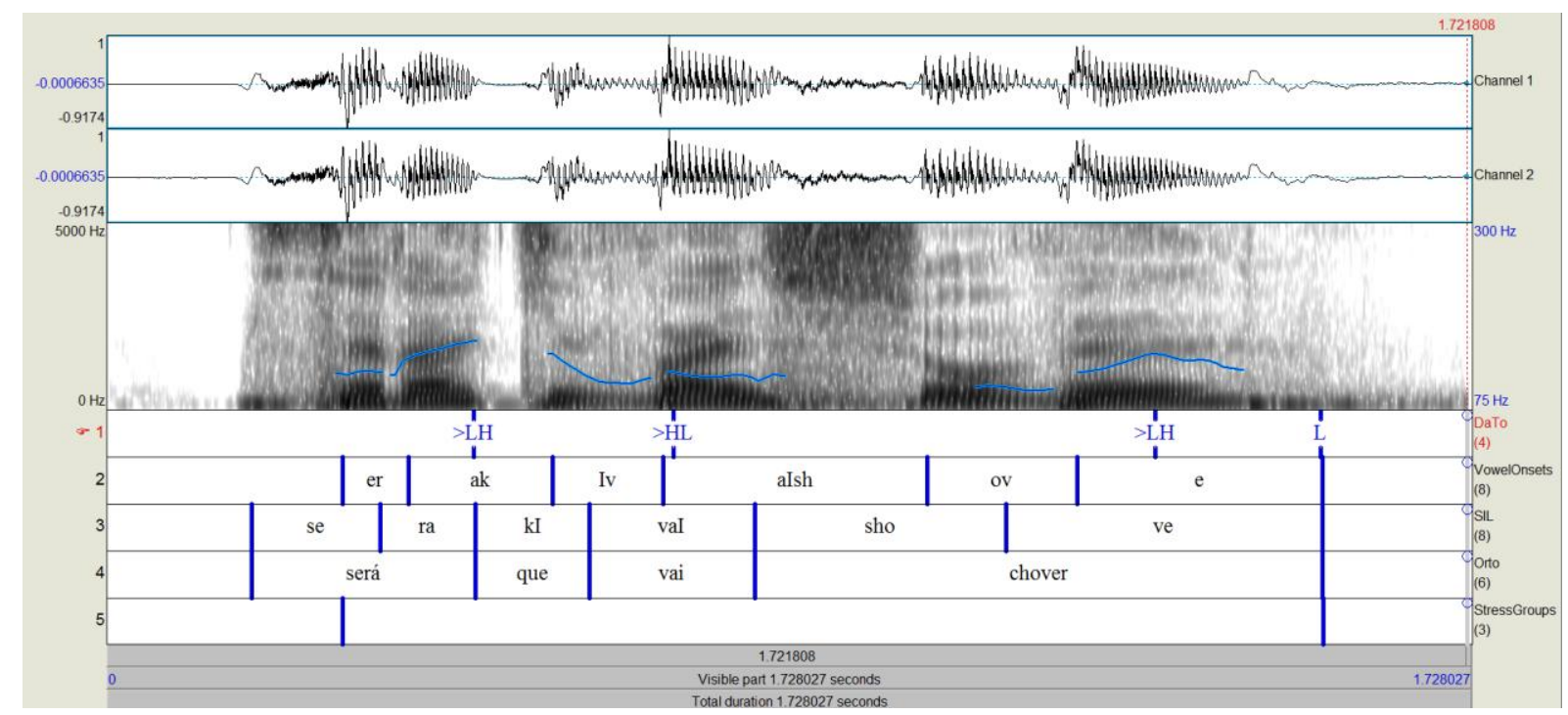

Figura 8: Exemplo de configuração dos rótulos com a notação DaTo (produção de C2)

Lucente (2012) comenta que manteve os rótulos similares à teoria Métrica Autossegmental por julgá-los mais produtivos e ilustrativos. Para os contornos ascendentes, os rótulos possíveis são LH (rising), >LH (late rising), vLH (compressed rising) e HLH (falling-rising). Para os contornos descendentes, os rótulos são LHL (rising-falling), HL (falling), >HL (late falling) e vHL (compressed falling). Após a rotulação dos contornos, foram calculadas as suas porcentagens de ocorrência por modalidades enunciativas. Também se contrastou os contornos dos colaboradores francófonos com aqueles produzidos por $\mathrm{C} 0$. 


\section{ANÁLISE E DISCUSSÃO DOS DADOS}

Este capítulo apresentará a análise dos dados e seus resultados. A discussão foi dividida em três etapas, duas acústicas e uma estatística, respectivamente: a análise das unidades VV segmentadas, o contraste das variações de f0 e a configuração da curva melódica com base no sistema notacional DaTo.

\section{1 Análise da duração das unidades VV}

As unidades VV foram escolhidas como um dos pontos de análise deste trabalho por evidenciarem, segundo Barbosa (2006), a estruturação rítmica dos enunciados.

Após o cálculo do z-score e do z-score suavizado de todos os enunciados, os dados foram contrastados sob os seguintes ângulos: línguas maternas, tempo de imersão e modalidade do enunciado. Para promover o contraste, primeiramente, os dados tiveram uma análise proveniente do script $S G$ Detector. Para cada enunciado, o script gera a duração, em milissegundos (ms), de cada unidade VV, os valores de $z$-score, z-score suavizado, a média e o desvio-padrão para os dados, bem como a quantidade de fronteiras dentro dos enunciados (pausas longas identificadas). Na Tabela 4, há uma amostra dos dados obtidos após o uso do SG Detector em um enunciado interrogativo.

\begin{tabular}{|c|c|c|c|c|}
\hline Segmentos Acústicos & $\begin{array}{c}\text { Duração } \\
(\mathrm{ms})\end{array}$ & $\begin{array}{c}\text { Z-score } \\
(\mathrm{c} 0)\end{array}$ & $\begin{array}{l}\text { Zsuav } \\
\text { (c0) }\end{array}$ & Fronteira \\
\hline Er & 66 & $-3,99$ & $-2,68$ & 0 \\
\hline $\mathrm{Ak}$ & 209 & $-0,06$ & $-1,37$ & 1 \\
\hline Iv & 75 & $-2,57$ & $-2,15$ & 0 \\
\hline aIsh & 178 & $-2,71$ & $-2,03$ & 0 \\
\hline Ov & 91 & $-2,79$ & $-1,55$ & 0 \\
\hline $\mathrm{E}$ & 173 & 3,32 & 1,28 & 1 \\
\hline Média e desvio-padrão: & & & 132 & 62 \\
\hline
\end{tabular}

Tabela 4: Valores de duração, z-score, z-score suavizado e fronteiras para cada unidade VV do enunciado "Será que vai chover?", produzido por C0. 
Após a extração dos dados provenientes do script SG Detector, fez-se comparações entre os dados. Sobre a duração das unidades VV, foram observadas:

- A diferença na duração (ms) entre colaboradores francófonos e controle de maneira geral;

- A diferença na duração (ms) entre colaboradores francófonos por tempo de imersão;

- A diferença na duração (ms) entre colaboradores e controle por língua materna;

- A diferença na duração (ms) entre colaboradores e controle por modalidade de enunciado;

Para a análise, definiu-se um nível de significância de 0,05 (5\%). Lembra-se também que todos os intervalos de confiança construídos ao longo do trabalho foram construídos com 95\% de confiança estatística.

A Tabela 5 mostra a comparação entre os colaboradores francófonos e controle com relação à média de duração (ms), ao valor de z-score e ao valor de z-score suavizado.

\begin{tabular}{|c|c|c|c|c|c|c|c|c|c|c|c|}
\hline Colabora & ores & Média & Mediana & $\begin{array}{l}\text { Desvio } \\
\text { Padrão }\end{array}$ & $\mathrm{CV}$ & Min & Max & $\mathbf{N}$ & IC & $\begin{array}{c}\text { F- } \\
\text { Fisher }\end{array}$ & P-valor \\
\hline \multirow{7}{*}{ Duração } & $\mathrm{C} 0$ & 158,7 & 141,0 & 70,4 & $44 \%$ & 47 & 503 & 77 & 15,7 & \multirow{7}{*}{5,42} & \multirow{7}{*}{$<0,001$} \\
\hline & $\mathrm{C} 1$ & 238,0 & 208,0 & 147,1 & $62 \%$ & 72 & 879 & 78 & 32,6 & & \\
\hline & $\mathrm{C} 2$ & 214,8 & 192,5 & 133,8 & $62 \%$ & 32 & 828 & 76 & 30,1 & & \\
\hline & C3 & 236,0 & 222,5 & 111,2 & $47 \%$ & 48 & 667 & 70 & 26,0 & & \\
\hline & $\mathrm{C} 4$ & 298,8 & 225,5 & 245,8 & $82 \%$ & 51 & 1.619 & 82 & 53,2 & & \\
\hline & $\mathrm{C} 5$ & 242,5 & 191,0 & 182,2 & $75 \%$ & 63 & 1.244 & 75 & 41,2 & & \\
\hline & C6 & 244,6 & 222,0 & 136,4 & $56 \%$ & 55 & 639 & 34 & 45,8 & & \\
\hline \multirow{7}{*}{ z-score } & $\mathrm{CO}$ & $-1,009$ & $-1,09$ & 2,320 & $-230 \%$ & $-4,38$ & 11,65 & 77 & 0,518 & \multirow{7}{*}{6,29} & \multirow{7}{*}{$<0,001$} \\
\hline & $\mathrm{C} 1$ & 1,735 & 0,51 & 4,690 & $270 \%$ & $-3,40$ & 20,27 & 78 & 1,041 & & \\
\hline & $\mathrm{C} 2$ & 0,688 & $-0,02$ & 4,109 & $597 \%$ & $-4,17$ & 28,08 & 76 & 0,924 & & \\
\hline & C3 & 1,243 & 0,70 & 2,842 & $229 \%$ & $-2,33$ & 15,27 & 70 & 0,666 & & \\
\hline & $\mathrm{C} 4$ & 2,997 & 1,12 & 6,390 & $213 \%$ & $-4,72$ & 35,38 & 82 & 1,383 & & \\
\hline & C5 & 1,256 & 0,15 & 4,170 & $332 \%$ & $-2,92$ & 17,95 & 75 & 0,944 & & \\
\hline & C6 & 1,675 & 0,65 & 3,315 & $198 \%$ & $-4,14$ & 8,90 & 34 & 1,114 & & \\
\hline \multirow{7}{*}{ z-suaviz } & $\mathrm{CO}$ & $-0,973$ & $-1,14$ & 1,249 & $-128 \%$ & $-3,41$ & 3,24 & 77 & 0,279 & \multirow{7}{*}{19,31} & \multirow{7}{*}{$<0,001$} \\
\hline & $\mathrm{C} 1$ & 1,669 & 0,95 & 2,344 & $140 \%$ & $-2,46$ & 8,27 & 78 & 0,520 & & \\
\hline & $\mathrm{C} 2$ & 0,692 & 0,24 & 1,987 & $287 \%$ & $-2,54$ & 10,53 & 76 & 0,447 & & \\
\hline & C3 & 1,251 & 1,16 & 1,572 & $126 \%$ & $-1,68$ & 7,00 & 70 & 0,368 & & \\
\hline & $\mathrm{C} 4$ & 2,959 & 2,13 & 3,681 & $124 \%$ & $-2,49$ & 14,70 & 82 & 0,797 & & \\
\hline & C5 & 1,291 & 0,72 & 2,547 & $197 \%$ & $-2,06$ & 9,52 & 75 & 0,576 & & \\
\hline & C6 & 1,537 & 1,30 & 2,287 & $149 \%$ & $-2,57$ & 6,17 & 34 & 0,769 & & \\
\hline
\end{tabular}

Tabela 5: Comparação entre duração (ms), z-score e z-score suavizado entre colaboradores francófonos e controle 
Para esses dados, a mediana é a divisão da análise ao meio, assim, 50\% dos colaboradores estão acima do valor e 50\%, abaixo. Assim, quanto mais próximo seu valor em relação à média, mais simétrica será a distribuição. A variabilidade é medida pelo desvio padrão, a quarta coluna. Quanto mais próximo esse valor é em relação à média, maior será é variabilidade. O Coeficiente de Variação (CV) é uma estatística que avalia como variabilidade representa a média: quanto mais baixo, mais homogêneos são os resultados. Mínimo e máximo indicam apenas os maiores e menores valores encontrados da amostra de dados. $\mathrm{O}$ intervalo de confiança (IC), ora somado e ora subtraído da média, mostra-nos a variação da média segundo uma probabilidade estatística.

Com a análise, conclui-se com os p-valores da Tabela 5 que há diferença média estatisticamente significante entre os todos os colaboradores nas três variáveis. A diferença ocorre principalmente entre $\mathrm{C} 0$ e os demais colaboradores. Nota-se que existe uma diferença média estatisticamente significante entre os seis colaboradores nas três variáveis: duração (ms), z-suave e z-score suavizado. Assim, para determinar entre quais colaboradores ocorre a diferença, utilizou-se a Comparação Múltipla de Tukey (Post Hoc) para comparar todos os colaboradores em pares e encontrar entre quais ocorreu a diferença. Assim, na Tabela 6, estão os p-valores destas comparações. Para compará-los, basta cruzar a linha com a coluna.

\begin{tabular}{|c|c|c|c|c|c|c|c|}
\hline & & $\mathrm{C} 0$ & $\mathrm{C} 1$ & $\mathrm{C} 2$ & C3 & $\mathrm{C} 4$ & C5 \\
\hline \multirow{6}{*}{ Duração } & $\mathrm{C} 1$ & 0,032 & & & & & \\
\hline & $\mathrm{C} 2$ & 0,305 & 0,971 & & & & \\
\hline & $\mathrm{C} 3$ & 0,051 & 1,000 & 0,984 & & & \\
\hline & $\mathrm{C} 4$ & $<0,001$ & 0,191 & 0,016 & 0,188 & & \\
\hline & $\mathrm{C} 5$ & 0,021 & 1,000 & 0,936 & 1,000 & 0,286 & \\
\hline & C6 & 0,119 & 1,000 & 0,971 & 1,000 & 0,634 & 1,000 \\
\hline \multirow{6}{*}{$z$-score } & $\mathrm{C} 1$ & 0,001 & & & & & \\
\hline & $\mathrm{C} 2$ & 0,179 & 0,735 & & & & \\
\hline & $\mathrm{C} 3$ & 0,026 & 0,993 & 0,987 & & & \\
\hline & $\mathrm{C} 4$ & $<0,001$ & 0,505 & 0,013 & 0,155 & & \\
\hline & $\mathrm{C} 5$ & 0,020 & 0,993 & 0,983 & 1,000 & 0,145 & \\
\hline & C6 & 0,039 & 1,000 & 0,923 & 0,999 & 0,736 & 0,999 \\
\hline \multirow{6}{*}{$\begin{array}{c}z- \\
\text { suavizadoado }\end{array}$} & $\mathrm{C} 1$ & $<0,001$ & & & & & \\
\hline & $\mathrm{C} 2$ & $<0,001$ & 0,146 & & & & \\
\hline & $\mathrm{C} 3$ & $<0,001$ & 0,937 & 0,794 & & & \\
\hline & $\mathrm{C} 4$ & $<0,001$ & 0,012 & $<0,001$ & $<0,001$ & & \\
\hline & $\mathrm{C5}$ & $<0,001$ & 0,958 & 0,717 & 1,000 & $<0,001$ & \\
\hline & $\mathrm{C6}$ & $<0,001$ & 1,000 & 0,605 & 0,997 & 0,056 & 0,999 \\
\hline
\end{tabular}

Tabela 6: P-valores entre colaboradores $(\mathrm{C} 1$ a $\mathrm{C} 6)$ contrastados com $\mathrm{C} 0$ 
Constata-se que nas três variáveis existe diferença média estatisticamente significante entre os grupos de colaboradores francófonos e C 0 . O As maiores delas estão nos valores de z-score suavizado, determinante para a estruturação rítmica da língua. Além disso, há discrepâncias também na duração (ms) em que a média de C0 foi de 158,7 contra 246,8 do grupo de C1 a C6 (p-valor <0,001).

Os gráficos box-plot comprovam os valores extremamente altos de duração, z-score e z-score suavizado entre $\mathrm{C} 0$ e colaboradores francófonos (C1 a C6):

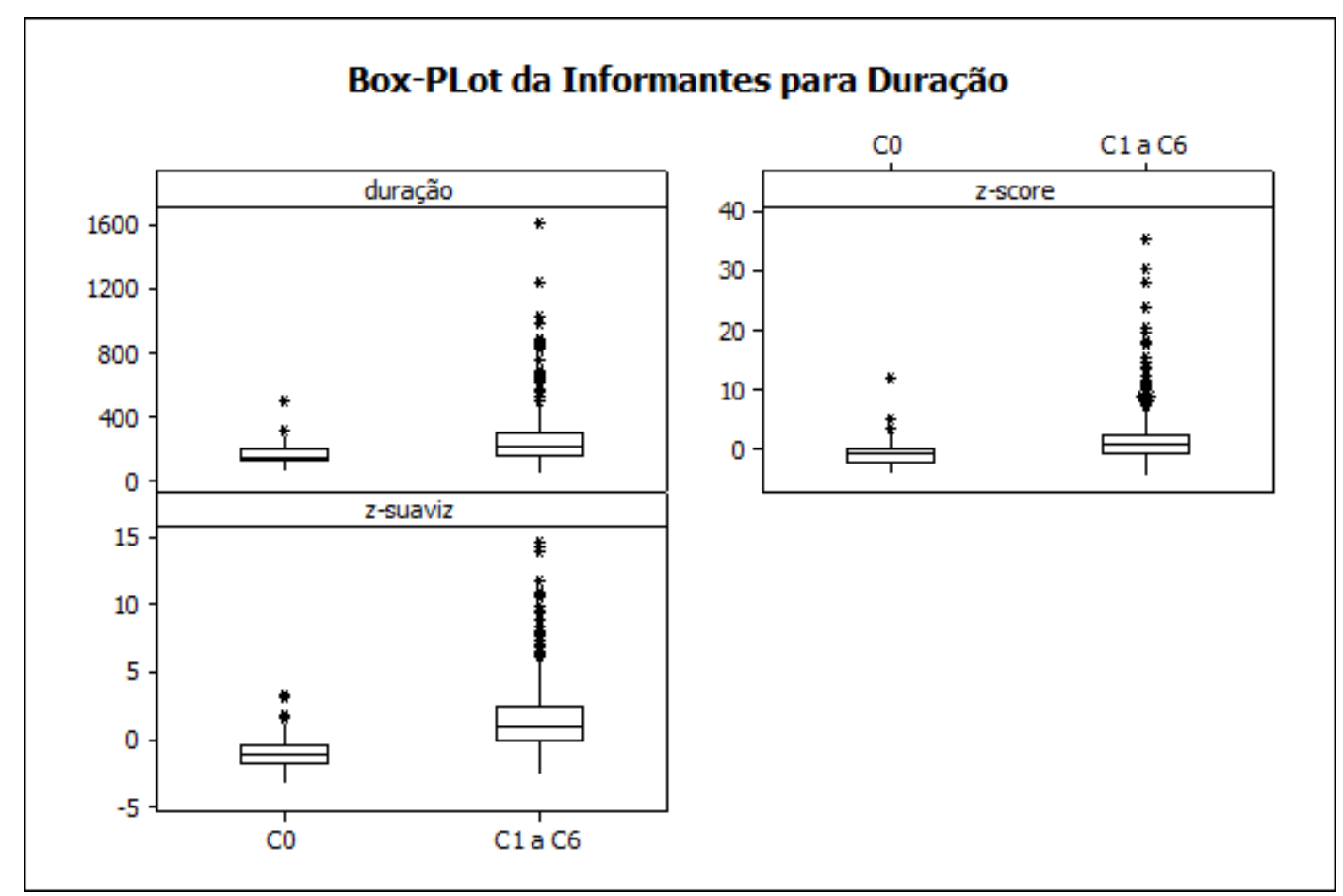

Figura 9: Gráficos box-plot para constatação do contraste entre $\mathrm{C} 0$ e os colaboradores francófonos para as variáves duração, z-score e z-score suavizado.

Os gráficos box-plot confirmam a assimetria da duração das unidades VV entre C0 e os colaboradores francófonos. Chama-se a atenção para a representação da duração e do zscore suavizado dos colaboradores por meio do gráfico de representação individual na figura 10: 


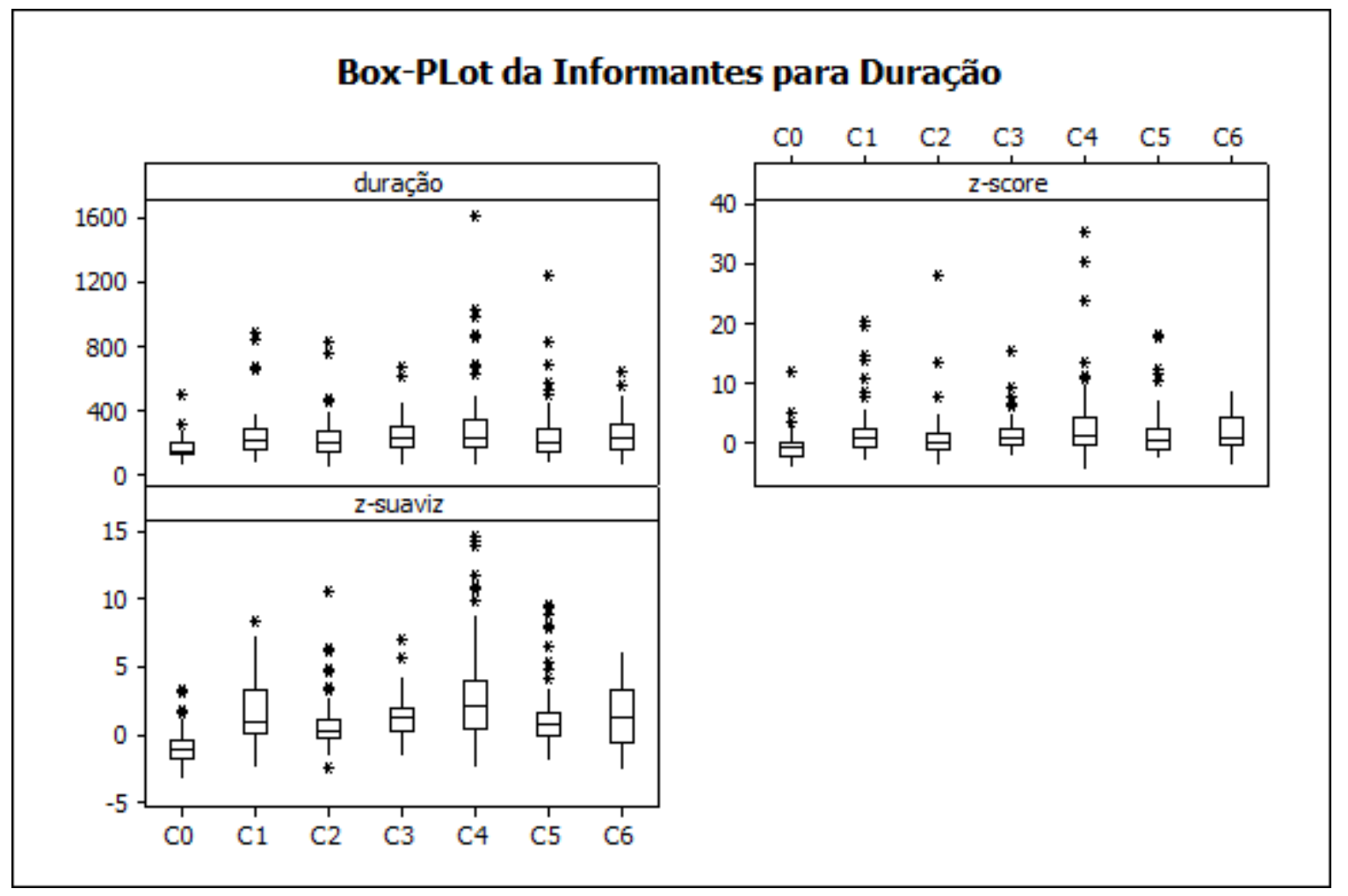

Figura 10: Gráficos box-plot para a constatação do contraste entre $\mathrm{C} 0$ e os colaboradores francófonos com representação individual para as variáves duração, $z$-score e z-score suavizado.

O próximo passo é comparar as variáveis individualmente, começando pela variável língua materna.

\begin{tabular}{|c|c|c|c|c|c|c|c|c|c|c|c|}
\hline & Língua & Média & Mediana & $\begin{array}{l}\text { Desvio } \\
\text { Padrão }\end{array}$ & $\mathrm{CV}$ & Min & Max & $\mathbf{N}$ & IC & $\begin{array}{c}\text { F- } \\
\text { Fisher }\end{array}$ & P-valor \\
\hline \multirow{4}{*}{ duração } & Ewondo & 236,0 & 222,5 & 111,2 & $47 \%$ & 48 & 667 & 70 & 26,0 & \multirow{4}{*}{10,36} & \multirow{4}{*}{$<0,001$} \\
\hline & Fon & 298,8 & 225,5 & 245,8 & $82 \%$ & 51 & 1.619 & 82 & 53,2 & & \\
\hline & Lingala & 233,4 & 198,0 & 152,8 & $65 \%$ & 32 & 1.244 & 263 & 18,5 & & \\
\hline & PB & 158,7 & 141,0 & 70,4 & $44 \%$ & 47 & 503 & 77 & 15,7 & & \\
\hline \multirow{4}{*}{ z-score } & Ewondo & 1,243 & 0,70 & 2,842 & $229 \%$ & $-2,33$ & 15,27 & 70 & 0,666 & \multirow{4}{*}{11,71} & \multirow{4}{*}{$<0,001$} \\
\hline & Fon & 2,997 & 1,12 & 6,390 & $213 \%$ & $-4,72$ & 35,38 & 82 & 1,383 & & \\
\hline & Lingala & 1,288 & 0,33 & 4,216 & $327 \%$ & $-4,17$ & 28,08 & 263 & 0,510 & & \\
\hline & PB & $-1,009$ & $-1,09$ & 2,320 & $-230 \%$ & $-4,38$ & 11,65 & 77 & 0,518 & & \\
\hline \multirow{4}{*}{$\begin{array}{c}\mathrm{Z}^{-} \\
\text {suaviz }\end{array}$} & Ewondo & 1,251 & 1,16 & 1,572 & $126 \%$ & $-1,68$ & 7,00 & 70 & 0,368 & \multirow{4}{*}{35,95} & \multirow{4}{*}{$<0,001$} \\
\hline & Fon & 2,959 & 2,13 & 3,681 & $124 \%$ & $-2,49$ & 14,70 & 82 & 0,797 & & \\
\hline & Lingala & 1,262 & 0,67 & 2,322 & $184 \%$ & $-2,57$ & 10,53 & 263 & 0,281 & & \\
\hline & PB & $-0,973$ & $-1,14$ & 1,249 & $-128 \%$ & $-3,41$ & 3,24 & 77 & 0,279 & & \\
\hline
\end{tabular}

Tabela 7: Comparação entre duração, $z$-score e $z$-score suavizado por L1 faladas pelos colaboradores.

A Tabela 7 evidencia informações importantes. Por ordem de duração de unidades VV, está, da maior para a menor: o fon, o ewondo e o lingala. O valor da duração das 
unidades VV do fon chega a ser quase duas vezes maior que as do PB. Com a tabela comparativa entre as línguas, pode-se analisar os p-valores disponíveis na Tabela 8.

\begin{tabular}{ccccc}
\hline & & Ewondo & Fon & Lingala \\
\hline \multirow{3}{*}{ Duração } & Fon & 0,072 & & \\
\cline { 2 - 5 } & Lingala & 0,999 & 0,006 & \\
\cline { 2 - 5 } z-score & PB & 0,017 & $<0,001$ & 0,002 \\
\cline { 2 - 5 } & Fon & 0,058 & & \\
\cline { 2 - 5 } & Lingala & 1,000 & 0,009 & \\
\cline { 2 - 5 } z- & PB & 0,008 & $<0,001$ & $<0,001$ \\
\cline { 2 - 5 } suavizado & Fon & $<0,001$ & & \\
\cline { 2 - 5 } & Lingala & 1,000 & $<0,001$ & \\
\cline { 2 - 5 } & PB & $<0,001$ & $<0,001$ & $<0,001$ \\
\hline
\end{tabular}

Tabela 8: P-valores obtidos pela comparação de variáveis da Tabela 7, que compara as línguas maternas de todos os colaboradores.

Na comparação com o p-valor estabelecido para esta amostra, há diferenças significativas entre os colaboradores por línguas faladas. Para isso, observamos inicialmente os p-valores maiores <0,001. Há discrepâncias consideráveis entre o PB e todas as línguas com relação à duração, ao z-score e ao z-score suavizado. Quanto à duração, as três línguas apresentaram distinções, sendo o fon aquela de maior discrepância. No que diz respeito ao zscore, ainda que todas as línguas apresentassem discrepâncias quanto ao PB, as maiores foram encontradas em contraste com o fon e o lingala. Observando os p-valores de z-score suavizado, as três línguas indicam discrepâncias consideráveis quando comparadas ao PB.

Entre as línguas da subfamília bantu, no quesito duração constata-se que há discrepâncias não apenas entre o fon e o lingala. Quanto ao z-score, essas diferenças são vistas entre o fon e lingala, mesmo que suavemente. Na comparação dos valores de $z$-score suavizado, foram notadas diferenças significativas entre o ewondo e o fon, como também entre o fon e o lingala.

Reitera-se a discrepância entre a duração das unidades VV na língua fon com relação ao PB: das três línguas, o fon foi aquela que apresentou mais discrepância, diferentemente do lingala. Quanto ao z-score suavizado, característica importante na percepção auditiva, todas as línguas apresentaram grandes distinções na comparação com o PB.

A Tabela 9 compara os colaboradores francófonos e controle em grupos, quanto ao tempo de imersão no PB: 


\begin{tabular}{|c|c|c|c|c|c|c|c|c|c|c|c|}
\hline Ime & são & Média & Mediana & $\begin{array}{c}\text { Desvio } \\
\text { Padrão } \\
\end{array}$ & CV & Min & Max & $\mathbf{N}$ & IC & $\begin{array}{c}\text { F- } \\
\text { Fisher }\end{array}$ & P-valor \\
\hline \multirow{4}{*}{ duração } & $\mathrm{CC}$ & 158,7 & 141,0 & 70,4 & $44 \%$ & 47 & 503 & 77 & 15,7 & \multirow{4}{*}{8,92} & \multirow{4}{*}{$<0,001$} \\
\hline & GA & 240,0 & 209,5 & 143,3 & $60 \%$ & 55 & 879 & 112 & 26,5 & & \\
\hline & GB & 271,9 & 211,0 & 218,9 & $81 \%$ & 51 & 1.619 & 157 & 34,2 & & \\
\hline & $\mathrm{GC}$ & 225,0 & 203,5 & 123,5 & $55 \%$ & 32 & 828 & 146 & 20,0 & & \\
\hline \multirow{4}{*}{ z-score } & $\mathrm{CC}$ & $-1,009$ & $-1,09$ & 2,320 & $-230 \%$ & $-4,38$ & 11,65 & 77 & 0,518 & \multirow{4}{*}{10,12} & \multirow{4}{*}{$<0,001$} \\
\hline & GA & 1,717 & 0,57 & 4,304 & $251 \%$ & $-4,14$ & 20,27 & 112 & 0,797 & & \\
\hline & GB & 2,165 & 0,59 & 5,496 & $254 \%$ & $-4,72$ & 35,38 & 157 & 0,860 & & \\
\hline & GC & 0,954 & 0,43 & 3,557 & $373 \%$ & $-4,17$ & 28,08 & 146 & 0,577 & & \\
\hline \multirow{4}{*}{ z-suaviz } & $\mathrm{CC}$ & $-0,973$ & $-1,14$ & 1,249 & $-128 \%$ & $-3,41$ & 3,24 & 77 & 0,279 & \multirow{4}{*}{30,40} & \multirow{4}{*}{$<0,001$} \\
\hline & GA & 1,629 & 1,14 & 2,318 & $142 \%$ & $-2,57$ & 8,27 & 112 & 0,429 & & \\
\hline & GB & 2,162 & 1,13 & 3,288 & $152 \%$ & $-2,49$ & 14,70 & 157 & 0,514 & & \\
\hline & GC & 0,960 & 0,67 & 1,816 & $189 \%$ & $-2,54$ & 10,53 & 146 & 0,295 & & \\
\hline
\end{tabular}

Tabela 9: comparação entre duração, $z$-score e $z$-score suavizado pelo tempo de imersão dos colaboradores francófonos e do controle.

Observando a média, encontra-se novamente a comprovação da duração maior das unidades VV dos colaboradores francófonos. Comparando os valores ao controle, há para a duração (ms) o valor de 158,7 para o controle contra 240 para GA, 271,9 para GB e 225 para GC. É curioso o fato de que, para a duração, o grupo que mais se aproxima da duração das unidades VV do colaborador controle é o GC, com menos tempo de imersão. Para o prosseguimento da discussão, a Tabela 10 mostra os p-valores encontrados pela Tabela 9.

\begin{tabular}{clccc}
\hline & & $\mathrm{CC}$ & $\mathrm{GA}$ & $\mathrm{GB}$ \\
\hline \multirow{3}{*}{ Duração } & GA & 0,003 & & \\
\cline { 2 - 5 } & GB & $<0,001$ & 0,368 & \\
\cline { 2 - 5 } z-score & GC & 0,017 & 0,876 & 0,052 \\
\cline { 2 - 5 } & GA & $<0,001$ & & \\
\cline { 2 - 5 } & GB & $<0,001$ & 0,833 & \\
\cline { 2 - 5 } z- & GC & 0,007 & 0,493 & 0,069 \\
\cline { 2 - 5 } suavizado & GA & $<0,001$ & & \\
\cline { 2 - 5 } & GB & $<0,001$ & 0,287 & \\
\cline { 2 - 5 } & GC & $<0,001$ & 0,126 & $<0,001$ \\
\hline
\end{tabular}

Tabela 10: P-valores obtidos pela comparação das variáveis da Tabela 9 , que contrasta os valores da duração, do z-score e do z-score suavizado por tempo de imersão dos colaboradores francófonos e controle.

Os dados obtidos pelo cálculo dos p-valores dos colaboradores por tempo de imersão indicam dados significativos. O grupo A (GA), com mais tempo de imersão, apresenta menor discrepância quanto à duração (ms) das unidades em comparação com os demais e essa discrepância é pouco significativa . O grupo B (GB) apresenta maior discrepância que o grupo 
C (GC), embora os dois valores indiquem discrepância. Isso indica que, para esse grupo, o tempo de imersão proporcionou menos interferência da L1 na duração das unidades VV. Uma análise entre os grupos mostra ainda que o grupo GC apresenta menos discrepância que o grupo GB, que conta com um falante da língua fon, dado importante por ser o grupo GC aquele com menos tempo de imersão. Para os valores de z-score suavizado, também determinantes da estrutura rítmica, observa-se que, em comparação com $\mathrm{C} 0$, todos os grupos apresentam discrepância significativa: p-valor $<0,001$.

Com o objetivo de identificar as diferenças entre as modalidades de enunciação, a Tabela 11 compara todos os enunciados por modalidade. De cada colaborador, foram selecionadas sete sentenças, resultando em 49 enunciados para a análise. São eles:

1. Declarativa I: Ela não me respeita;

2. Declarativa II: Eles estavam em casa esperando a mãe chegar com as roupas molhadas;

3. Declarativa III: Eu já tinha pedido pra ela colocar as coisas no lugar, mas não adianta, ela não me obedece;

4. Injuntiva I: Arruma seu quarto, menina;

5. Injuntiva II: Arruma seu quarto;

6. Interrogativa I: Será que vai chover?

7. Interrogativa II: Você já organizou seu quarto hoje?

\begin{tabular}{|c|c|c|c|c|c|c|c|c|c|c|c|}
\hline & Modalidade & Média & Mediana & $\begin{array}{l}\text { Desvio } \\
\text { Padrão }\end{array}$ & $\mathrm{CV}$ & Min & Max & $\mathbf{N}$ & IC & $\begin{array}{c}\text { F- } \\
\text { Fisher }\end{array}$ & P-valor \\
\hline \multirow{7}{*}{ duração } & Declarativa I & 209,2 & 215,0 & 94,7 & $45 \%$ & 43 & 457 & 61 & 23,8 & \multirow{7}{*}{3,99} & \multirow{7}{*}{0,001} \\
\hline & $\begin{array}{c}\text { Declarativa } \\
\text { II }\end{array}$ & 254,9 & 208,5 & 151,5 & $59 \%$ & 59 & 1.034 & 130 & 26,0 & & \\
\hline & $\begin{array}{c}\text { Declarativa } \\
\text { III }\end{array}$ & 269,7 & 207,5 & 224,9 & $83 \%$ & 49 & 1.619 & 134 & 38,1 & & \\
\hline & Injuntiva & 186,3 & 179,5 & 93,6 & $50 \%$ & 46 & 551 & 32 & 32,4 & & \\
\hline & Injuntiva I & 152,2 & 137,0 & 66,4 & $44 \%$ & 47 & 333 & 27 & 25,1 & & \\
\hline & $\begin{array}{c}\text { Interrogativa } \\
\text { I }\end{array}$ & 189,8 & 175,5 & 126,8 & $67 \%$ & 32 & 829 & 42 & 38,3 & & \\
\hline & $\begin{array}{c}\text { Interrogativa } \\
\text { II }\end{array}$ & 220,4 & 198,5 & 132,5 & $60 \%$ & 48 & 843 & 66 & 32,0 & & \\
\hline \multirow{3}{*}{ z-score } & Declarativa I & 0,988 & 0,69 & 2,179 & $221 \%$ & $\begin{array}{c}- \\
3,45\end{array}$ & 6,30 & 61 & 0,547 & \multirow{3}{*}{1,93} & \multirow{3}{*}{0,075} \\
\hline & $\begin{array}{c}\text { Declarativa } \\
\text { II }\end{array}$ & 1,519 & 0,53 & 4,671 & $308 \%$ & $4, \overline{72}$ & 35,38 & 130 & 0,803 & & \\
\hline & $\begin{array}{c}\text { Declarativa } \\
\text { III }\end{array}$ & 2,002 & 0,21 & 5,867 & $293 \%$ & - & 30,44 & 134 & 0,993 & & \\
\hline
\end{tabular}




\begin{tabular}{|c|c|c|c|c|c|c|c|c|c|c|c|}
\hline & Injuntiva & 0,370 & 0,48 & 1,893 & $512 \%$ & $\begin{array}{c}- \\
4,14 \\
\end{array}$ & 4,98 & 32 & 0,656 & & \\
\hline & Injuntiva I & $-0,251$ & $-0,80$ & 1,967 & $-782 \%$ & $\begin{array}{c}- \\
2,67 \\
\end{array}$ & 6,00 & 27 & 0,742 & & \\
\hline & $\begin{array}{c}\text { Interrogativa } \\
\text { I } \\
\end{array}$ & 0,676 & $-0,50$ & 3,841 & $568 \%$ & $\begin{array}{c}- \\
4,17 \\
\end{array}$ & 12,32 & 42 & 1,162 & & \\
\hline & $\begin{array}{l}\text { Interrogativa } \\
\text { II } \\
\end{array}$ & 0,523 & $-0,44$ & 3,629 & $693 \%$ & $\begin{array}{c}- \\
3,55 \\
\end{array}$ & 20,27 & 66 & 0,876 & & \\
\hline \multirow{7}{*}{$\begin{array}{l}\mathrm{Z}^{-} \\
\text {suaviz }\end{array}$} & Declarativa I & 1,051 & 1,12 & 1,226 & $117 \%$ & $\begin{array}{c}- \\
1,78 \\
\end{array}$ & 3,97 & 61 & 0,308 & \multirow{7}{*}{6,22} & \multirow{7}{*}{$<0,001$} \\
\hline & $\begin{array}{c}\text { Declarativa } \\
\text { II }\end{array}$ & 1,477 & 0,98 & 2,577 & $174 \%$ & $\begin{array}{c}- \\
3,41 \\
\end{array}$ & 13,93 & 130 & 0,443 & & \\
\hline & $\begin{array}{c}\text { Declarativa } \\
\text { III }\end{array}$ & 2,027 & 0,88 & 3,428 & $169 \%$ & $2,-$ & 14,70 & 134 & 0,580 & & \\
\hline & Injuntiva & 0,284 & 0,14 & 1,223 & $431 \%$ & 2,57 & 3,61 & 32 & 0,424 & & \\
\hline & Injuntiva I & $-0,419$ & $-0,40$ & 0,941 & $-224 \%$ & $\begin{array}{c}- \\
2,00 \\
\end{array}$ & 1,49 & 27 & 0,355 & & \\
\hline & $\begin{array}{c}\text { Interrogativa } \\
\text { I } \\
\end{array}$ & 0,668 & 0,32 & 2,620 & $392 \%$ & $\begin{array}{c}- \\
2,68 \\
\end{array}$ & 7,90 & 42 & 0,792 & & \\
\hline & $\begin{array}{l}\text { Interrogativa } \\
\text { II }\end{array}$ & 0,508 & $-0,25$ & 2,191 & $432 \%$ & $\begin{array}{c}- \\
2,10\end{array}$ & 8,27 & 66 & 0,529 & & \\
\hline
\end{tabular}

Tabela 11: Comparação de enunciados por modalidades sob as variáveis duração, $z$-score e $z$-score suavizado.

O cálculo dos p-valores indica os dados para a refutação da hipótese da discrepância entre duração das unidades VV nas modalidades de enunciação, como é possível notar na Tabela 12.

\begin{tabular}{|c|c|c|c|c|c|c|c|}
\hline & & $\begin{array}{c}\text { Declarativa } \\
\text { I }\end{array}$ & $\begin{array}{c}\text { Declarativa } \\
\text { II }\end{array}$ & $\begin{array}{c}\text { Declarativa } \\
\text { III }\end{array}$ & Injuntiva & $\begin{array}{c}\text { Injuntiva } \\
\text { I }\end{array}$ & $\begin{array}{c}\text { Interrogativa } \\
\text { I }\end{array}$ \\
\hline \multirow{6}{*}{ Duração } & Declarativa II & 0,521 & & & & & \\
\hline & Declarativa III & 0,182 & 0,989 & & & & \\
\hline & Injuntiva I & 0,995 & 0,312 & 0,114 & & & \\
\hline & Injuntiva II & 0,718 & 0,040 & 0,010 & 0,983 & & \\
\hline & Interrogativa I & 0,997 & 0,249 & 0,073 & 1,000 & 0,963 & \\
\hline & Interrogativa II & 1,000 & 0,785 & 0,384 & 0,957 & 0,504 & 0,961 \\
\hline \multirow{6}{*}{$z$-score } & Declarativa II & & & & & & \\
\hline & Declarativa III & & & & & & \\
\hline & Injuntiva I & & & & & & \\
\hline & Injuntiva II & & & & & & \\
\hline & Interrogativa I & & & & & & \\
\hline & Interrogativa II & & & & & & \\
\hline \multirow{6}{*}{$\begin{array}{c}z- \\
\text { suavizado }\end{array}$} & Declarativa II & 0,936 & & & & & \\
\hline & Declarativa III & 0,172 & 0,584 & & & & \\
\hline & Injuntiva I & 0,816 & 0,217 & 0,010 & & & \\
\hline & Injuntiva II & 0,166 & 0,009 & $<0,001$ & 0,941 & & \\
\hline & Interrogativa I & 0,990 & 0,561 & 0,044 & 0,995 & 0,601 & \\
\hline & Interrogativa II & 0,896 & 0,159 & 0,002 & 1,000 & 0,691 & 1,000 \\
\hline
\end{tabular}


Tabela 12: P-valores obtidos pela comparação das variáveis da Tabela 11, que contrasta os valores da duração, do z-score e do z-score suavizado dos enunciados por modalidade.

Os p-valores mostram que, de maneira geral, não há diferenças significativas nos enunciados se comparados quanto à modalidade. O valor de z-score suavizado é o único que apresenta diferença significativa na modalidade injuntiva II em comparação à sentença declarativa III. Observa-se que os p-valores para o z-score são pouco divergentes, por isso, não há valor numérico em suas linhas.

De maneira geral, embora não tenha havido grandes diferenças na comparação entre modalidades, observa-se que as maiores discrepâncias estão no valor da duração das unidades VV entre $\mathrm{C} 0$ e os colaboradores francófonos. Para mostrar mais claramente essas divergências, foram elaborados gráficos comparativos de amostra entre cada colaborador francófono e C0.

Para esta parte da amostragem, foi escolhido um enunciado de cada modalidade, partindo de enunciados declarativos, em seguida interrogativos e declarativos. A Figura 11 evidencia, por meio de gráficos, as divergências entre as produções do Grupo A e C0.

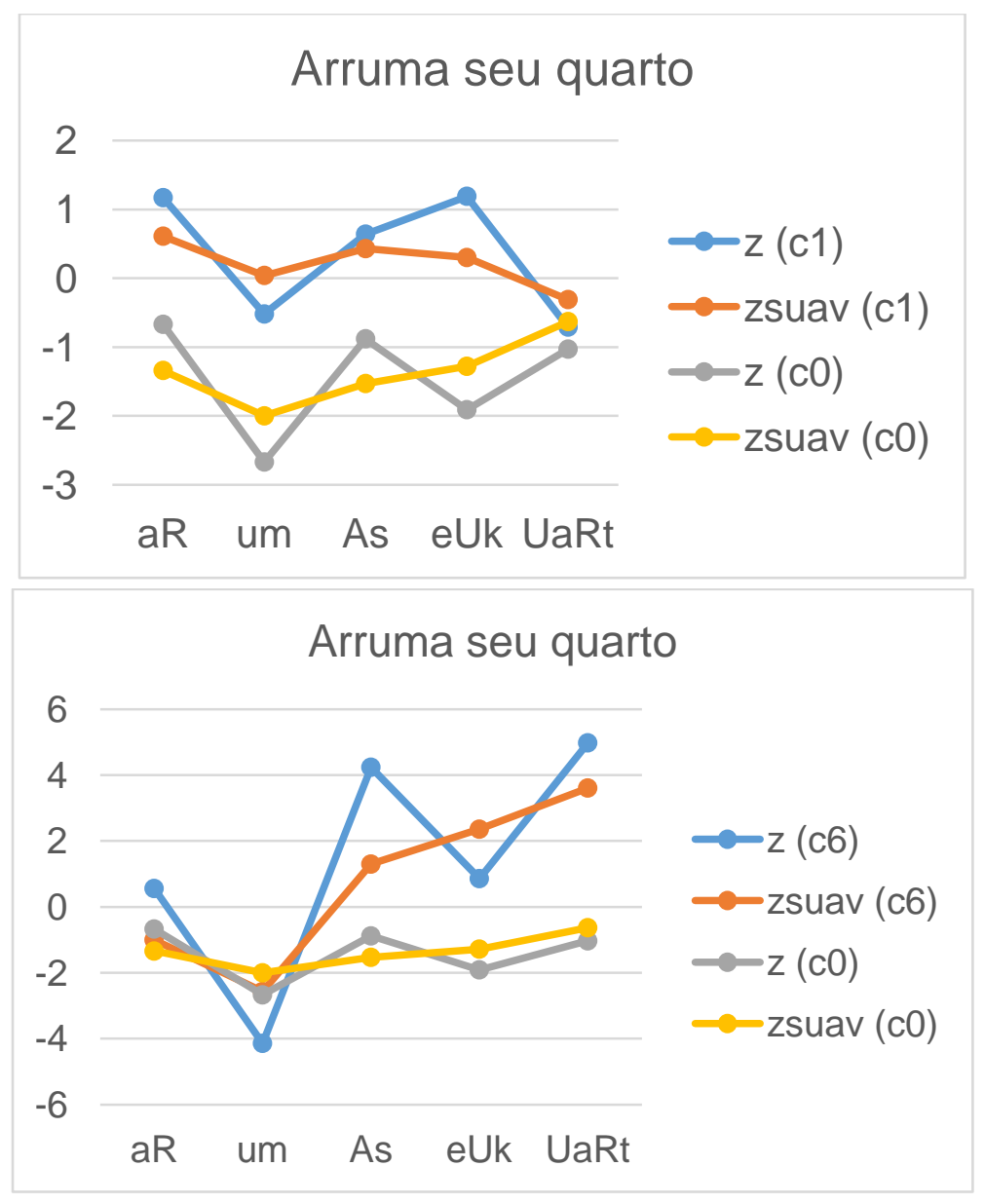


Figura 11: Comparativo entre os valores médios de z-score e z-score suavizado, no enunciado injuntivo "arruma seu quarto", entre C0 e Grupo A.

No contraste entre o Grupo A e C0, pode-se constatar que há diferenças significativas entre as produções. Observando os valores e a configuração dos gráficos, o primeiro ponto a ser mencionado é a duração das unidades VV nas produções do Grupo A, que é maior que a produção de $\mathrm{C} 0$. Para esta análise, o melhor foco é na curva de $z$-score suavizado, pois evidencia as proeminências mais marcadas e, por isso, mais fáceis de serem percebidas pelo interlocutor. Ainda que haja durações de unidades VV maiores nas produções do grupo A que na de $\mathrm{C} 0$, as proeminências evidenciam semelhanças nas sílabas tônicas e pretônicas, com exceção brusca na unidade [eUk], com duração de 247 milissegundos, no enunciado produzido por $\mathrm{C}$ 1, que apresenta um aumento significativo de $z$-score para 1,19 contra $-1,91$ de $\mathrm{C} 0$.

A Figura 12 mostra a duração das unidades VV em um enunciado interrogativo.

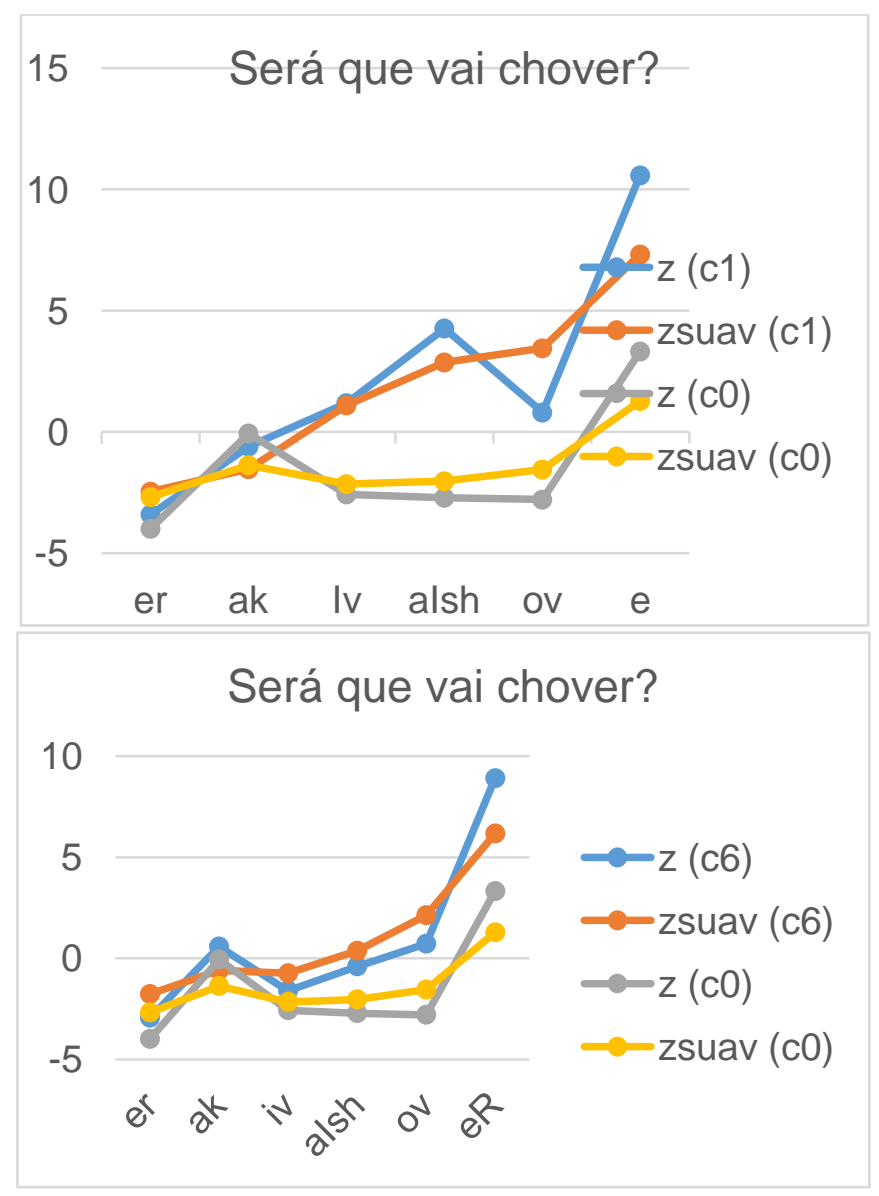

Figura 12: Comparativo entre os valores médios de z-score e z-score suavizado, no enunciado interrogativo "Será que vai chover?", entre C0 e Grupo A. 
No contraste de enunciados interrogativos, como em "Será que vai chover?", observa-se uma duração longa das unidades VV nas produções do Grupo A em comparação a $\mathrm{C} 0$, porém, menor que no enunciado injuntivo. A consonância entre os picos é maior, na comparação do z-score suavizado, estando a produção do Grupo A mais próxima de C0. O alto pico de [aIsh] para a produção de C1 evidencia-se pela duração de 335 milissegundos contra 178 milissegundos de C0, apresentando uma média de z-score suavizado de 4,27, diferentemente de $\mathrm{C} 0$, com $-2,71$.

A Figura 13 mostra a duração das unidades VV em um enunciado declarativo.

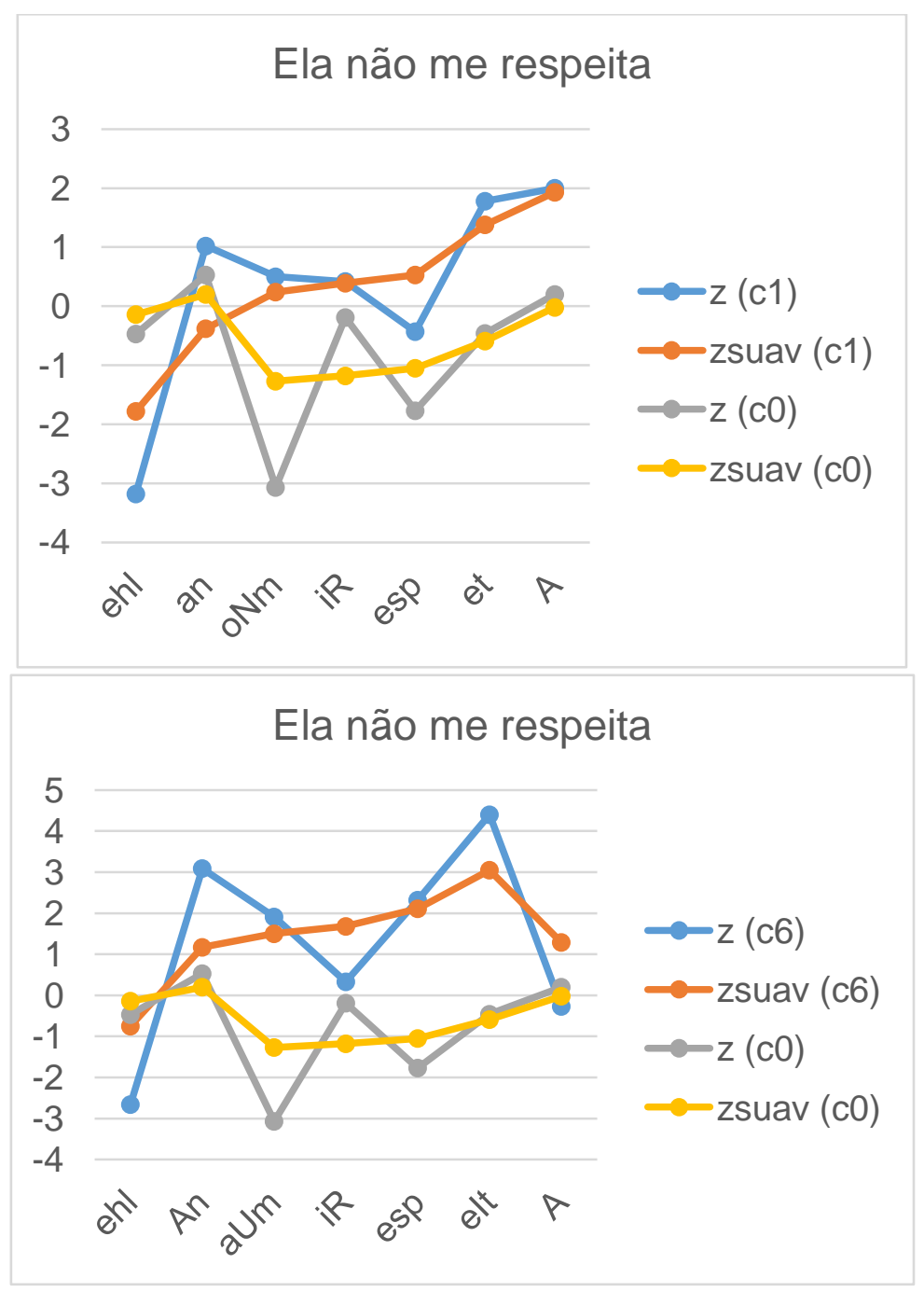

Figura 13: Comparativo entre os valores médios de z-score e z-score suavizado, no enunciado declarativo "Ela não me respeita", entre C0 e Grupo A.

O contraste entre o enunciado declarativo da Figura 13 apresenta novamente durações distintas entre as unidades VV. Um ponto importante é que essas unidades tiveram 
durações mais próximas no início dos enunciados, contudo, os picos apresentaram ocorrências diferentes. Foram três picos, com maior duração das unidades VV nas sílabas tônicas, para a produção de $\mathrm{C} 0$ e apenas um para $\mathrm{C} 1$ e dois para C6. C1 não faz grande distinção de duração silábica para a marcação de ênfase nas sílabas tônicas, um pouco diferentemente de C6, que apresenta o pico em [eIt], por exemplo, mais marcado.

A Figura 14 mostra o primeiro exemplo de análise realizada em contraste entre o Grupo B e C0.

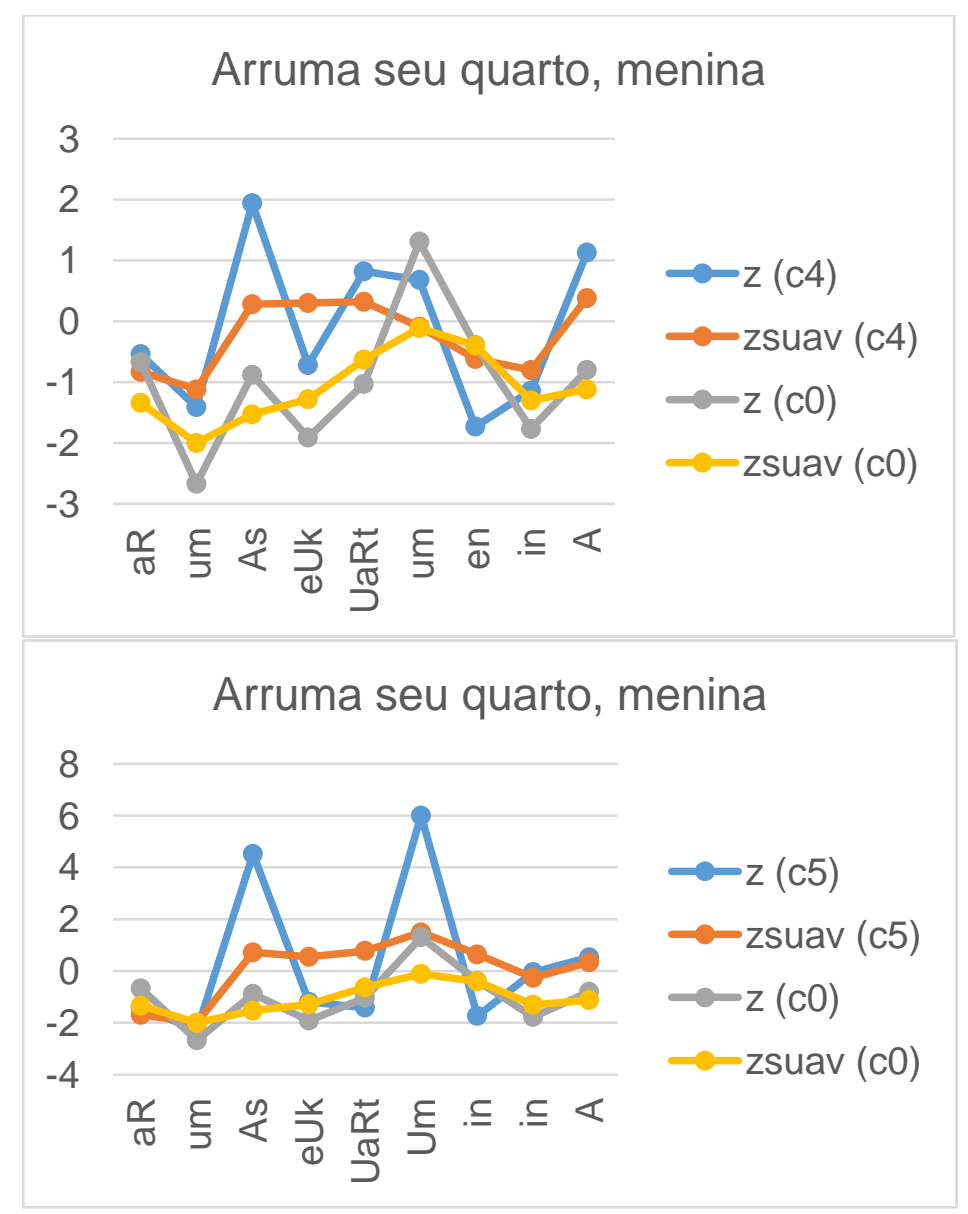

Figura 14: Comparativo entre os valores médios de z-score e z-score suavizado, no enunciado injuntivo "Arruma seu quarto, menina", entre $\mathrm{C} 0$ e Grupo B.

O Grupo B, composto por colaboradores com 2 anos e 10 meses de imersão, apresenta picos em posições semelhantes aos dados de C0, como é possível notar em [As], [um] e [A] na fronteira. As durações das unidades VV, quando comparadas, são maiores que 
aquelas produzidas por $\mathrm{C} 0$, entretanto, não tão distintas se comparadas aos dados do Grupo A. São dados importantes a duração da unidade [As], tanto para C4 quanto para C5: 210 e 283 milissegundos, respectivamente, contra 130 milissegundos de $\mathrm{C} 0$.

A Figura 15 mostra outro exemplo de análise realizada em contraste entre o Grupo B e C0, dessa vez, em um enunciado interrogativo.

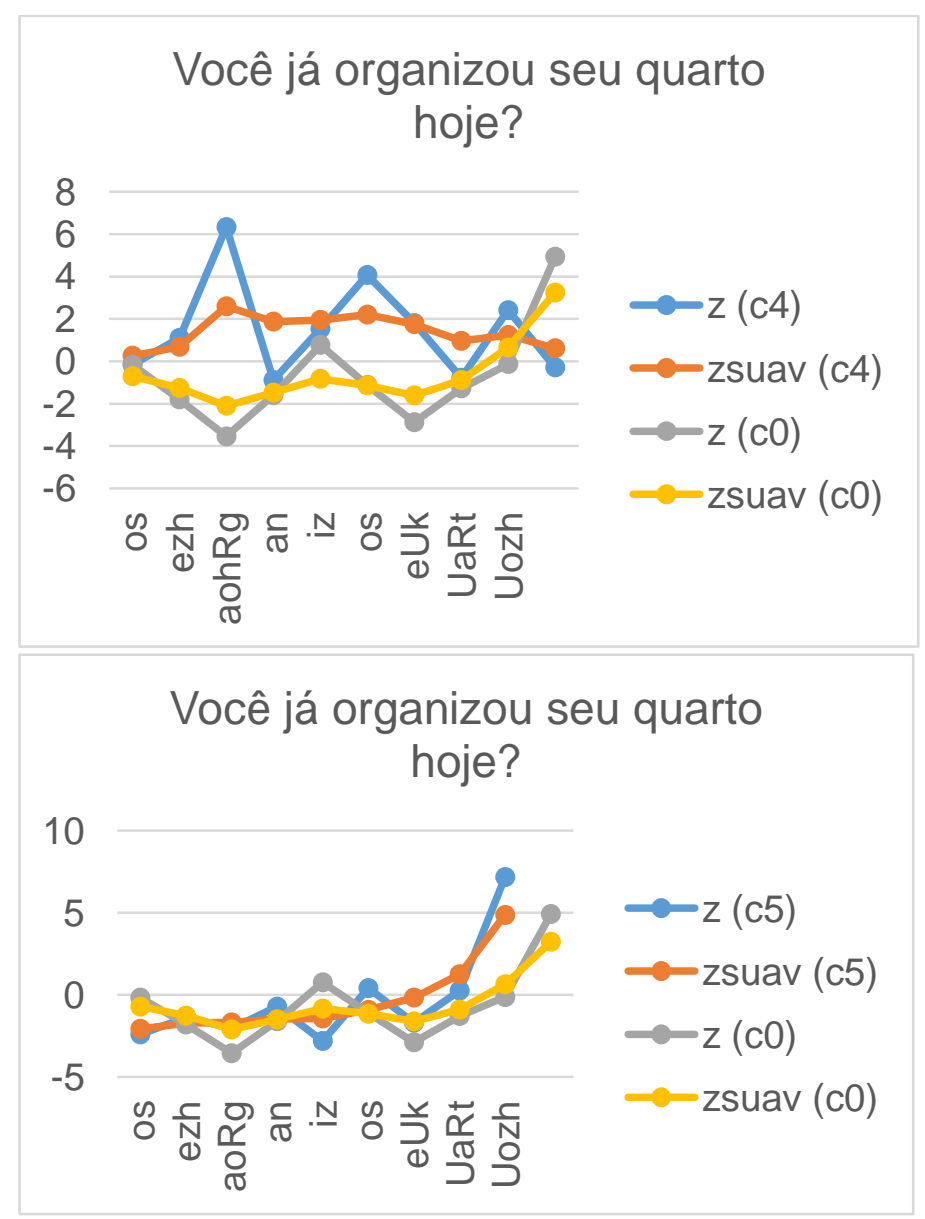

Figura 15: Comparativo entre os valores médios de z-score e z-score suavizado, no enunciado interrogativo "Você já organizou seu quarto hoje?", entre C0 e Grupo B.

Nos dados da Figura 15, fica claro que ainda que agrupados por tempo de imersão, os falantes têm desempenhos distintos quanto à produção rítmica. Nesta análise, os picos de C4 são distintos significantemente de $\mathrm{C} 0$ : os picos são quase opostos, o que indica que a marcação das proeminências é muito destoante. A primeira observação para a unidade VV [aoRg], que tem duração de 671 milissegundos para C4 e apenas 106 para C0. Quanto à produção de C5, as durações são aproximadas àquelas de $\mathrm{C} 0$. Na unidade [aoRg], há durações muito próximas, com valores de z-score suavizado de -1,67 para C5 e 2,1 para C0. 
A Figura 16 mostra mais exemplo de análise realizada em contraste entre o Grupo B e C0, dessa vez, em um enunciado declarativo.

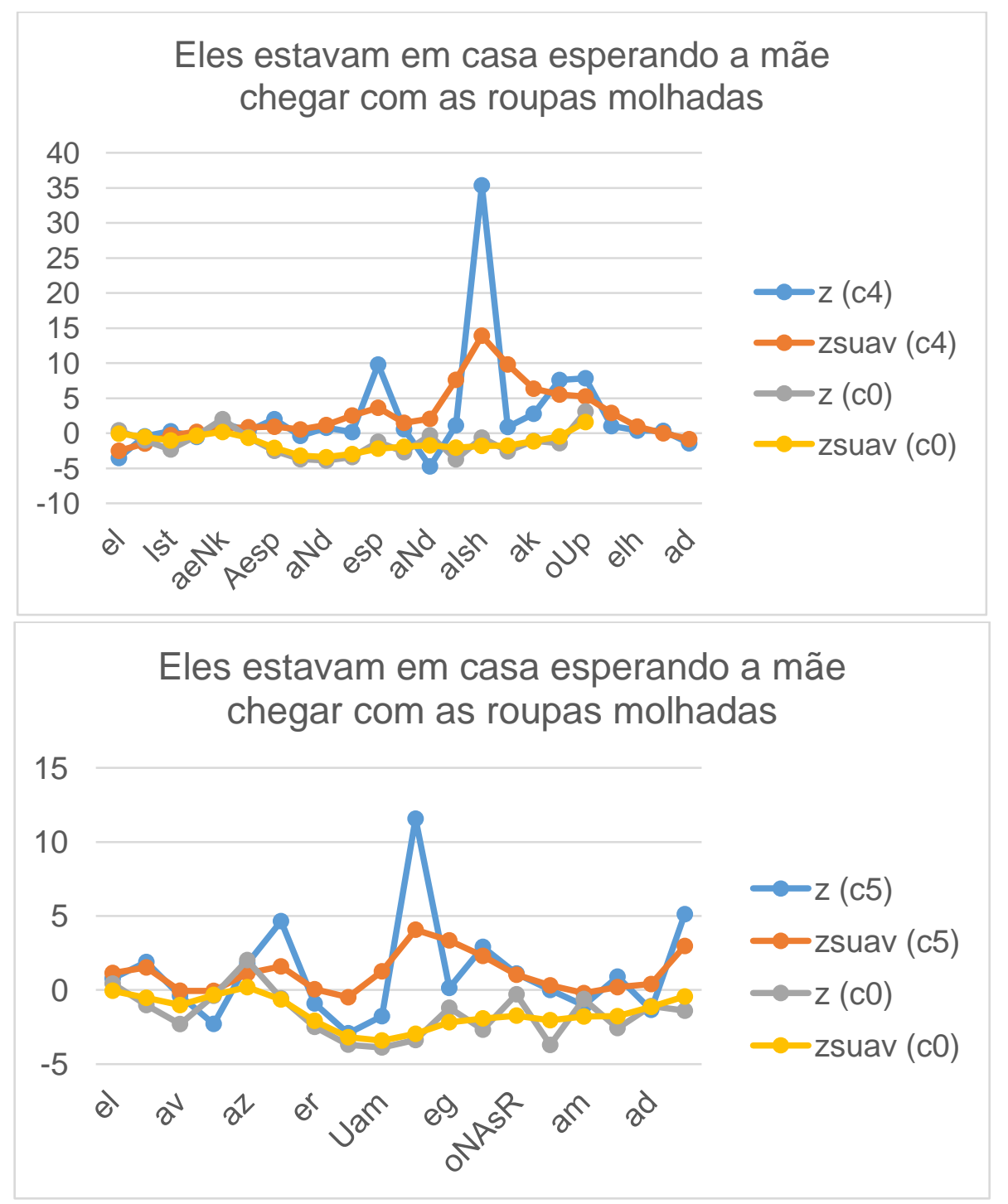

Figura 16: Comparativo entre os valores médios de z-score e $z$-score suavizado, no enunciado declarativo "Eles estavam em casa esperando a mãe chegar com as roupas molhadas", entre C0 e Grupo B.

No enunciado declarativo "Eles estavam em casa esperando a mãe chegar com as roupas molhadas", observa-se que a duração das unidades VV do grupo B está mais próxima de C0. Observa-se a consoância entre picos, especificamente, nas unidades VV [el], [av], 
[aeNk] e [az], na primeira parte do enunciado. Chama-se atenção para o maior pico dos dois enunciados, [aIsh] com duração de 1034 milissegundos na produção de C4, 449 na C5, contra 212 milissegundos na produção de $\mathrm{C} 0$.

A série de análises abaixo traz informações acerca dos contrastes realizados entre o Grupo C e C0.

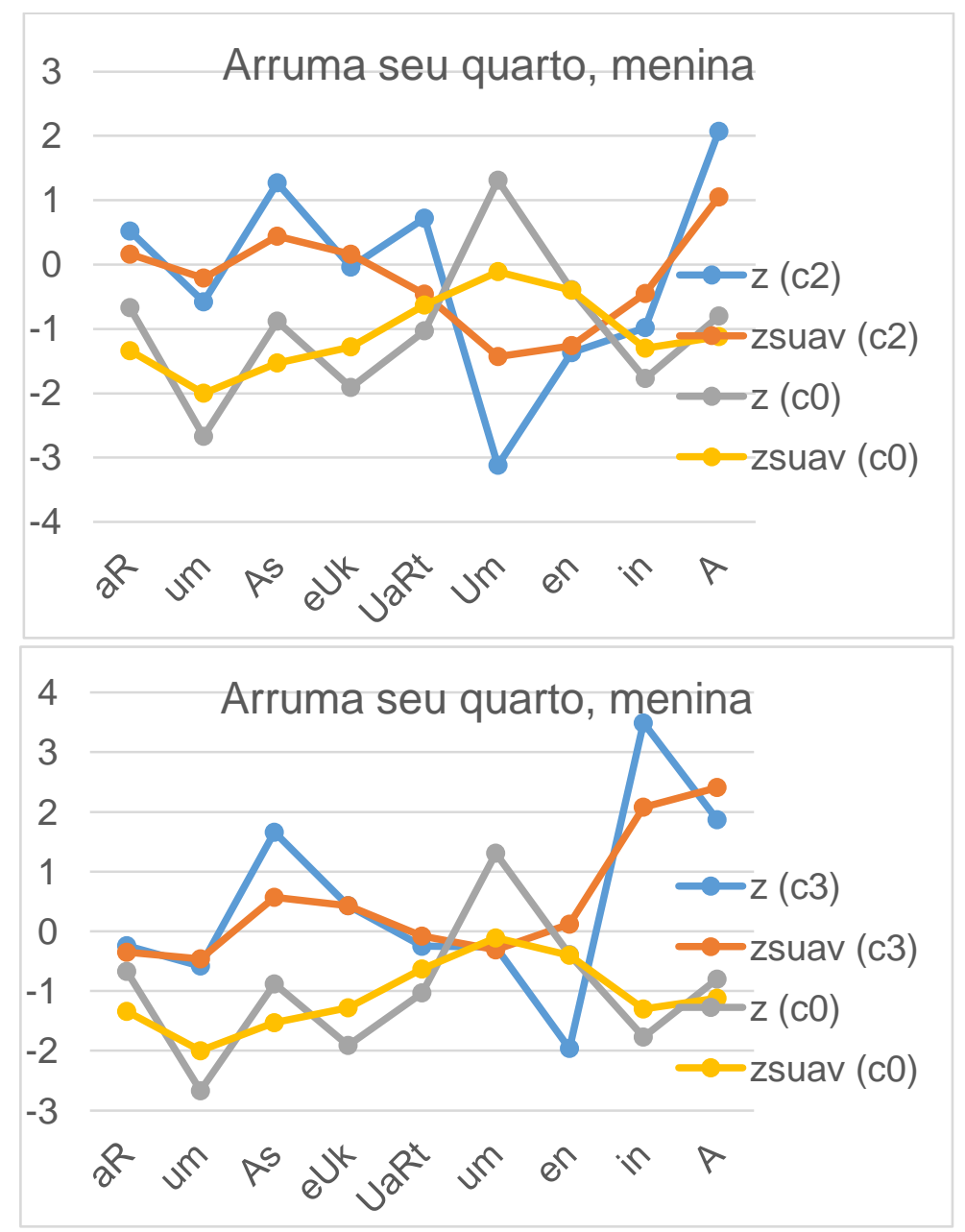

Figura 17: Comparativo entre os valores médios de z-score e z-score suavizado, no enunciado injuntivo "Arruma seu quarto, menina", entre $\mathrm{C} 0$ e Grupo $\mathrm{C}$.

O Grupo C, constituído pelos colaboradores com menor tempo de imersão, apresenta diferença significativa de duração na unidade VV [Um], produzida por C2 e nas fronteiras de ambas as produções, na unidade VV [A]. No caso de [Um], em posição postônica, a duração em milissegundos para $\mathrm{C} 2$ foi de 46 com $-1,43$ de z-score suavizado, contra 134 milissegundos de $\mathrm{C} 0$, com $-0,11$. Nesse caso, excepcionalmente, a duração da unidade $\mathrm{VV}$ foi 
menor que a de C0. Nas fronteiras dos enunciados, também há discrepância significativa na duração das unidades VV, que muito se distinguem nos padrões de C0.

A Figura 18 mostra outro exemplo de análise realizada em contraste entre o Grupo C e C0, dessa vez, em um enunciado interrogativo.

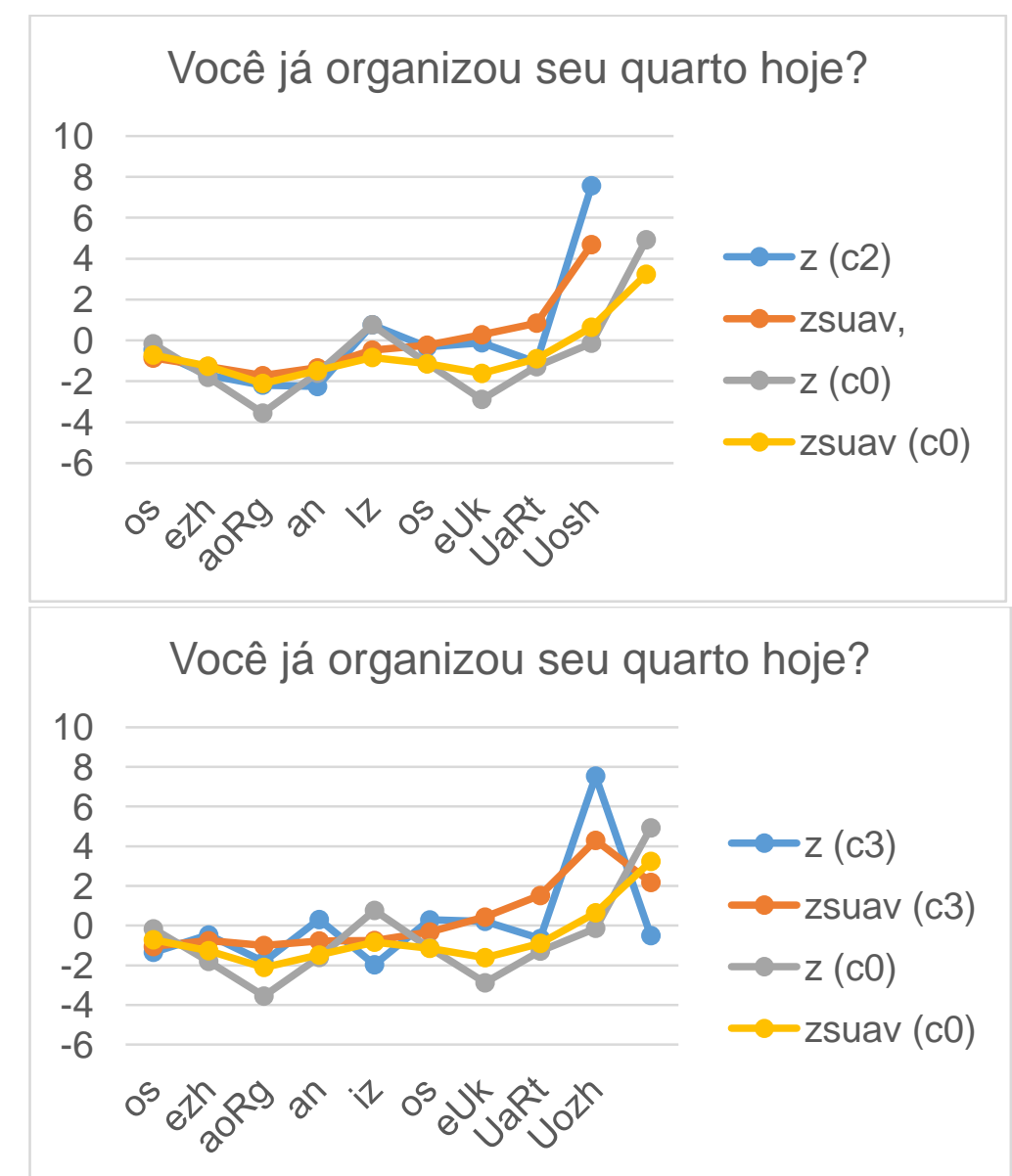

Figura 18: Comparativo entre os valores médios de z-score e $z$-score suavizado, no enunciado interrogativo "Arruma seu quarto, menina", entre C0 e Grupo C.

Na Figura 18, pode-se notar que há grande consonância na duração das unidades VV no enunciado interrogativo entre o Grupo C e C0. Há uma quantidade idêntica de picos, um na unidade [iz] e outro na unidade [UaRt]. A duração da unidade VV [iz] foi idêntica, 141 milissegundos, para C2 e C0, e teve o valor de 141 milissegundos para C3.

A Figura 19 mostra o último exemplo de análise realizada em contraste entre o Grupo C e C0, dessa vez, em um enunciado declarativo. 


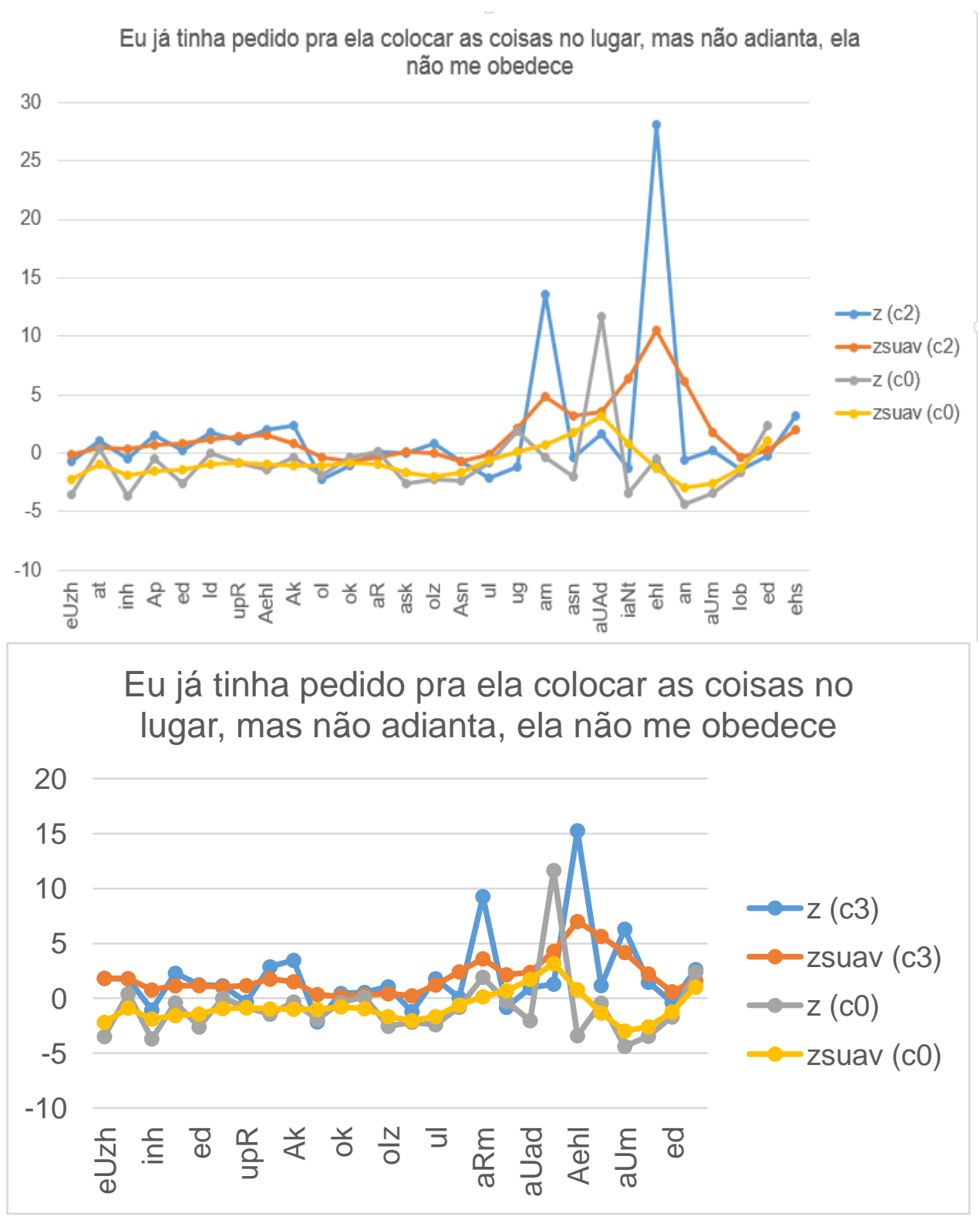

Figura 19: Comparativo entre os valores médios de z-score e z-score suavizado, no enunciado declarativo "Eu já tinha pedido pra ela colocar as coisas no lugar, mas não adianta, ela não me obedece", entre C0 e Grupo C.

A figura 19 indica uma harmonia rítmica significativa entre o Grupo 3 e C0. Para C0, há quatro picos de proeminência na linha de $z$-score, enquanto há 6 picos para $\mathrm{C} 2$ e cinco para C3. As unidades VV de maior ênfase para ambos são [aRm], [Iant] e [ehs]. Essas unidades, portanto, apresentam maior duração. Para C2, suas durações são de, respectivamente, 828, 263 e 368 milissegundos. Para C3, 667, 307 e 268 milissegundos, contra 315, 503 e 279 milissegundos de $\mathrm{C} 0$. 


\subsubsection{Considerações acerca da discrepância da duração das unidades VV}

Analisando o contraste das unidades VV entre colaborares dos grupos A, B e C com C0, observou-se que nos enunciados interrogativos há menos discrepâncias na duração das unidades VV que nos demais enunciados. O colaborador que mais apresentou diferenças em contraste com $\mathrm{C} 0$ em enunciados interrogativos foi $\mathrm{C} 4$, único falante da língua fon como língua materna. Quanto aos enunciados declarativos, os únicos colaboradores que não apresentaram divergências altas em z-score suavizado foram C3 e C2, integrantes do Grupo C. Para os enunciados injuntivos, C4, C5 e C6 apresentaram duração das unidades VV mais próximas de $\mathrm{C} 0$.

Dessa maneira, considera-se que o tempo de imersão dos colaboradores não influi diretamente na aquisição da estrutura rítmica do PB, pois integrantes do grupo $\mathrm{C}$, com menos tempo de imersão apresentam, por exemplo, apresentaram estrutura rítmica mais aproximada do PB para enunciados declarativos que aqueles que integram o grupo A, com quase quatro anos de imersão. Além disso, observou-se que são os enunciados interrogativos produzidos pelos colaborares, os que mais tem duração rítmica aproximada da estrutura do PB, de acordo com os parâmetros do colaborador controle. Os enunciados injuntivos e, principalmente, os declarativos dos colaboradores são os que divergem quanto ao padrão rítmico do $\mathrm{PB}$, de acordo com os dados.

A estrutura das línguas maternas desses colaboradores influi mais diretamente na aquisição rítmica do PB que qualquer outro fator. Para o colaborador $\mathrm{C} 4$, falante da língua fon, por exemplo, há uma transferência relacionada ao tom. Sua língua materna apresenta quatro tons e ainda um alongamento fonológico de vogais. Esse alongamento também é frequente em outras línguas como o lingala, falada pelos colaboradores C1, C2, C5 e C6. Nessas línguas de subfamília bantu, as unidades tonais funcionam como determinantes e são percebidas como pausas reais da voz, fenômeno muitas vezes encontrado nos dados desses colaboradores.

\subsection{A análise da variação da frequência fundamental (f0) e a adoção do sistema DaTo para a notação entoacional}


Nas subseções seguintes estão as análises das variações da frequência fundamental (f0), a apresentação dos dados estatísticos dessa etapa, a aplicação do sistema DaTo e as discussões acerca da frequência dos rótulos em comparação ao colaborador controle, à modalidade enunciativa e às línguas maternas dos colaboradores francófonos.

\subsubsection{A variação da frequência fundamental}

Para conhecer a variação de f0 dos colaboradores francófonos com relação ao colaborador controle, foram calculados manualmente f0 máxima, mínima e sua variação (subtração de f0 mínima de f0 máxima). Dessa forma, foi possível notar claramente as variações, como é possível constatar na tabela abaixo:

\begin{tabular}{|c|c|c|c|c|c|c|c|c|c|c|c|}
\hline \multicolumn{2}{|c|}{ Colaborador } & $\begin{array}{c}\text { Médi } \\
\text { a }\end{array}$ & $\begin{array}{c}\text { Median } \\
\mathbf{a}\end{array}$ & $\begin{array}{l}\text { Desvio } \\
\text { Padrã }\end{array}$ & $\mathrm{CV}$ & Min & Max & $\mathbf{N}$ & IC & $\begin{array}{c}\text { F- } \\
\text { Fisher }\end{array}$ & P-valor \\
\hline \multirow{7}{*}{ f0 mín. } & $\mathrm{CO}$ & 119,4 & 117,0 & 12,3 & $10 \%$ & 97 & 159 & 31 & 4,3 & \multirow{7}{*}{74,63} & \multirow{7}{*}{$<0,001$} \\
\hline & $\overline{\mathrm{C} 1}$ & 114,2 & 112,5 & 12,4 & $11 \%$ & 94 & 142 & 24 & 5,0 & & \\
\hline & $\overline{\mathrm{C} 2}$ & 136,0 & 137,5 & 16,6 & $12 \%$ & 80 & 168 & 30 & 5,9 & & \\
\hline & $\overline{\mathrm{C} 3}$ & 191,8 & 191,0 & 25,9 & $13 \%$ & 152 & 248 & 31 & 9,1 & & \\
\hline & $\overline{\mathrm{C} 4}$ & 103,9 & 102,0 & 11,3 & $11 \%$ & 78 & 143 & 34 & 3,8 & & \\
\hline & $\overline{\mathrm{C} 5}$ & 131,8 & 130,5 & 14,9 & $11 \%$ & 77 & 155 & 28 & 5,5 & & \\
\hline & $\overline{\mathrm{C} 6}$ & 135,1 & 131,0 & 38,6 & $29 \%$ & 76 & 239 & 11 & 22,8 & & \\
\hline \multirow{7}{*}{ f0 máx. } & $\mathrm{C} 0$ & 140,3 & 141,0 & 17,3 & $12 \%$ & 104 & 170 & 31 & 6,1 & \multirow{7}{*}{25,04} & \multirow{7}{*}{$<0,001$} \\
\hline & $\overline{\mathrm{C} 1}$ & 147,7 & 137,0 & 46,6 & $32 \%$ & 113 & 292 & 24 & 18,6 & & \\
\hline & $\overline{\mathrm{C} 2}$ & 163,9 & 161,0 & 28,2 & $17 \%$ & 128 & 295 & 30 & 10,1 & & \\
\hline & C3 & 228,8 & 217,0 & 28,8 & $13 \%$ & 187 & 283 & 31 & 10,2 & & \\
\hline & $\overline{\mathrm{C} 4}$ & 136,6 & 121,5 & 40,2 & $29 \%$ & 107 & 283 & 34 & 13,5 & & \\
\hline & $\overline{\mathrm{C} 5}$ & 164,1 & 154,0 & 39,8 & $24 \%$ & 120 & 297 & 28 & 14,7 & & \\
\hline & $\overline{\mathrm{C} 6}$ & 164,3 & 156,0 & 38,3 & $23 \%$ & 134 & 274 & 11 & 22,6 & & \\
\hline \multirow{7}{*}{$\begin{array}{l}\text { f0 } \\
\text { range }\end{array}$} & $\mathrm{C} 0$ & 20,9 & 15,0 & 16,2 & $78 \%$ & 3 & 55 & 31 & 5,7 & \multirow{7}{*}{0,76} & \multirow{7}{*}{0,600} \\
\hline & $\mathrm{C} 1$ & 33,5 & 19,0 & 45,8 & $137 \%$ & 3 & 187 & 24 & 18,3 & & \\
\hline & $\overline{\mathrm{C} 2}$ & 27,9 & 18,0 & 30,5 & $109 \%$ & 3 & 160 & 30 & 10,9 & & \\
\hline & $\overline{\mathrm{C} 3}$ & 37,0 & 35,0 & 19,7 & $53 \%$ & 4 & 78 & 31 & 6,9 & & \\
\hline & $\overline{\mathrm{C} 4}$ & 32,7 & 18,0 & 38,7 & $118 \%$ & 4 & 156 & 34 & 13,0 & & \\
\hline & $\overline{\mathrm{C} 5}$ & 32,3 & 16,0 & 40,1 & $124 \%$ & 3 & 168 & 28 & 14,9 & & \\
\hline & $\overline{\text { C6 }}$ & 29,2 & 24,0 & 23,5 & $81 \%$ & 3 & 87 & 11 & 13,9 & & \\
\hline
\end{tabular}

Tabela 13: Comparação dos valores de f0 para as produções dos colaboradores francófonos e controle (mín., máx. e range) 
Após a organização da Tabela 13 e da obtenção do p-valor padrão, foram calculados os p-valores em comparação a cada colaborador.

\begin{tabular}{|c|c|c|c|c|c|c|c|}
\hline & & $\mathrm{C} 0$ & C1 & $\mathrm{C} 2$ & C3 & C4 & C5 \\
\hline \multirow{6}{*}{ f0 mín. } & C1 & 0,944 & & & & & \\
\hline & $\mathrm{C} 2$ & 0,009 & $<0,001$ & & & & \\
\hline & $\mathrm{C} 3$ & $<0,001$ & $<0,001$ & $<0,001$ & & & \\
\hline & $\mathrm{C} 4$ & 0,014 & 0,353 & $<0,001$ & $<0,001$ & & \\
\hline & $\mathrm{C} 5$ & 0,130 & 0,012 & 0,977 & $<0,001$ & $<0,001$ & \\
\hline & C6 & 0,187 & 0,033 & 1,000 & $<0,001$ & $<0,001$ & 0,999 \\
\hline \multirow{6}{*}{ f0 máx.. } & $\mathrm{C} 1$ & 0,985 & & & & & \\
\hline & $\mathrm{C} 2$ & 0,112 & 0,611 & & & & \\
\hline & C3 & $<0,001$ & $<0,001$ & $<0,001$ & & & \\
\hline & $\mathrm{C} 4$ & 1,000 & 0,891 & 0,031 & $<0,001$ & & \\
\hline & $\mathrm{C} 5$ & 0,119 & 0,614 & 1,000 & $<0,001$ & 0,034 & \\
\hline & C6 & 0,432 & 0,844 & 1,000 & $<0,001$ & 0,246 & 1,000 \\
\hline \multirow{6}{*}{$\begin{array}{l}\text { f0 } \\
\text { range }\end{array}$} & C1 & & & & & & \\
\hline & $\mathrm{C} 2$ & & & & & & \\
\hline & $\mathrm{C} 3$ & & & & & & \\
\hline & $\mathrm{C} 4$ & & & & & & \\
\hline & $\mathrm{C} 5$ & & & & & & \\
\hline & C6 & & & & & & \\
\hline
\end{tabular}

Tabela 14: p-valores obtidos pela análise da Tabela 13, que evidencia os valores de f0 (min, máx., e range)

Observa-se que não há discrepância significativa com relação aos valores de f0 range. Entretanto, entre si, os colaboradores francófonos podem apresentar discrepâncias significativas de f0 mínima e máxima. Em f0 máxima, há discrepâncias como, por exemplo, entre $\mathrm{C} 1$ e $\mathrm{C} 2, \mathrm{C} 2$ e $\mathrm{C} 4, \mathrm{C} 5$ e C6. Esses dados se confirmam quando agrupamos os colaboradores por línguas que falam, como é perceptível na Tabela 15.

\begin{tabular}{|c|c|c|c|c|c|c|c|c|c|c|c|}
\hline \multicolumn{2}{|c|}{ Língua } & Média & Mediana & $\begin{array}{l}\text { Desvio } \\
\text { Padrão }\end{array}$ & $\mathrm{CV}$ & Min & Max & $\mathbf{N}$ & IC & F-fisher & P-valor \\
\hline \multirow{4}{*}{$\begin{array}{l}\text { f0 } \\
\text { mín. }\end{array}$} & Ewondo & 191,8 & 191,0 & 25,9 & $13 \%$ & 152 & 248 & 31 & 9,1 & \multirow{4}{*}{128,80} & \multirow{4}{*}{$<0,001$} \\
\hline & Fon & 103,9 & 102,0 & 11,3 & $11 \%$ & 78 & 143 & 34 & 3,8 & & \\
\hline & Lingala & 129,0 & 129,0 & 20,8 & $16 \%$ & 76 & 239 & 93 & 4,2 & & \\
\hline & PB & 119,4 & 117,0 & 12,3 & $10 \%$ & 97 & 159 & 31 & 4,3 & & \\
\hline \multirow{4}{*}{$\begin{array}{l}\text { f0 } \\
\text { máx. }\end{array}$} & Ewondo & 228,8 & 217,0 & 28,8 & $13 \%$ & 187 & 283 & 31 & 10,2 & \multirow{4}{*}{48,50} & \multirow{4}{*}{$<0,001$} \\
\hline & Fon & 136,6 & 121,5 & 40,2 & $29 \%$ & 107 & 283 & 34 & 13,5 & & \\
\hline & Lingala & 159,8 & 153,0 & 38,3 & $24 \%$ & 113 & 297 & 93 & 7,8 & & \\
\hline & PB & 140,3 & 141,0 & 17,3 & $12 \%$ & 104 & 170 & 31 & 6,1 & & \\
\hline \multirow{3}{*}{$\begin{array}{l}\text { f0 } \\
\text { range }\end{array}$} & Ewondo & 37,0 & 35,0 & 19,7 & $53 \%$ & 4 & 78 & 31 & 6,9 & \multirow{3}{*}{1,38} & \multirow{3}{*}{0,250} \\
\hline & Fon & 32,7 & 18,0 & 38,7 & $118 \%$ & 4 & 156 & 34 & 13,0 & & \\
\hline & Lingala & 30,8 & 19,0 & 36,8 & $120 \%$ & 3 & 187 & 93 & 7,5 & & \\
\hline
\end{tabular}


Tabela 15: comparação dos valores de f0 (min, máx., e range) para as produções dos colaboradores francófonos e controle agrupados por L1.

Por uma análise obtida pelos dados estatísticos, nota-se que as línguas apresentam discrepâncias entre si, especialmente se comparamos os p-valores na Tabela 16:

\begin{tabular}{ccccc}
\hline & & Ewondo & Fon & Lingala \\
\hline \multirow{2}{*}{ f0 } & Fon & $<0,001$ & & \\
\cline { 2 - 5 } mín. & Lingala & $<0,001$ & $<0,001$ & \\
\cline { 2 - 5 } f0 & PB & $<0,001$ & 0,008 & 0,078 \\
\cline { 2 - 5 } máx.. & Fon & $<0,001$ & & \\
\cline { 2 - 5 } f0 & Lingala & $<0,001$ & 0,005 & \\
\cline { 2 - 5 } range & Fon & & & \\
\cline { 2 - 5 } & Lingala & & & \\
\cline { 2 - 5 } & PB & & & \\
\hline
\end{tabular}

Tabela 16: P-valores obtidos pela análise da Tabela 15, que evidencia os valores de f0 (min, máx., e range) para as produções dos colaboradores francófonos e controle agrupados por L1.

Pelos p-valores disponíveis na Tabela 16, ainda que não haja discrepâncias significativas de f0 range, observa-se que, se compararmos entre as línguas, todas elas têm ocorrências de discrepâncias quanto à f0 máxima e mínima se comparadas à língua ewondo. Além disse, chama-se também a atenção para a discrepância entre as línguas fon e lingala. Quanto aos contrastes das línguas africanas com o PB, constata-se que tas línguas que apresentam discrepâncias de f0 mínima são o ewondo e o fon. Para f0 máxima, essas discrepâncias se encontram apenas em contraste com o ewondo e lingala. Os gráficos boxsplot na Figura 20 constatam as divergências: 


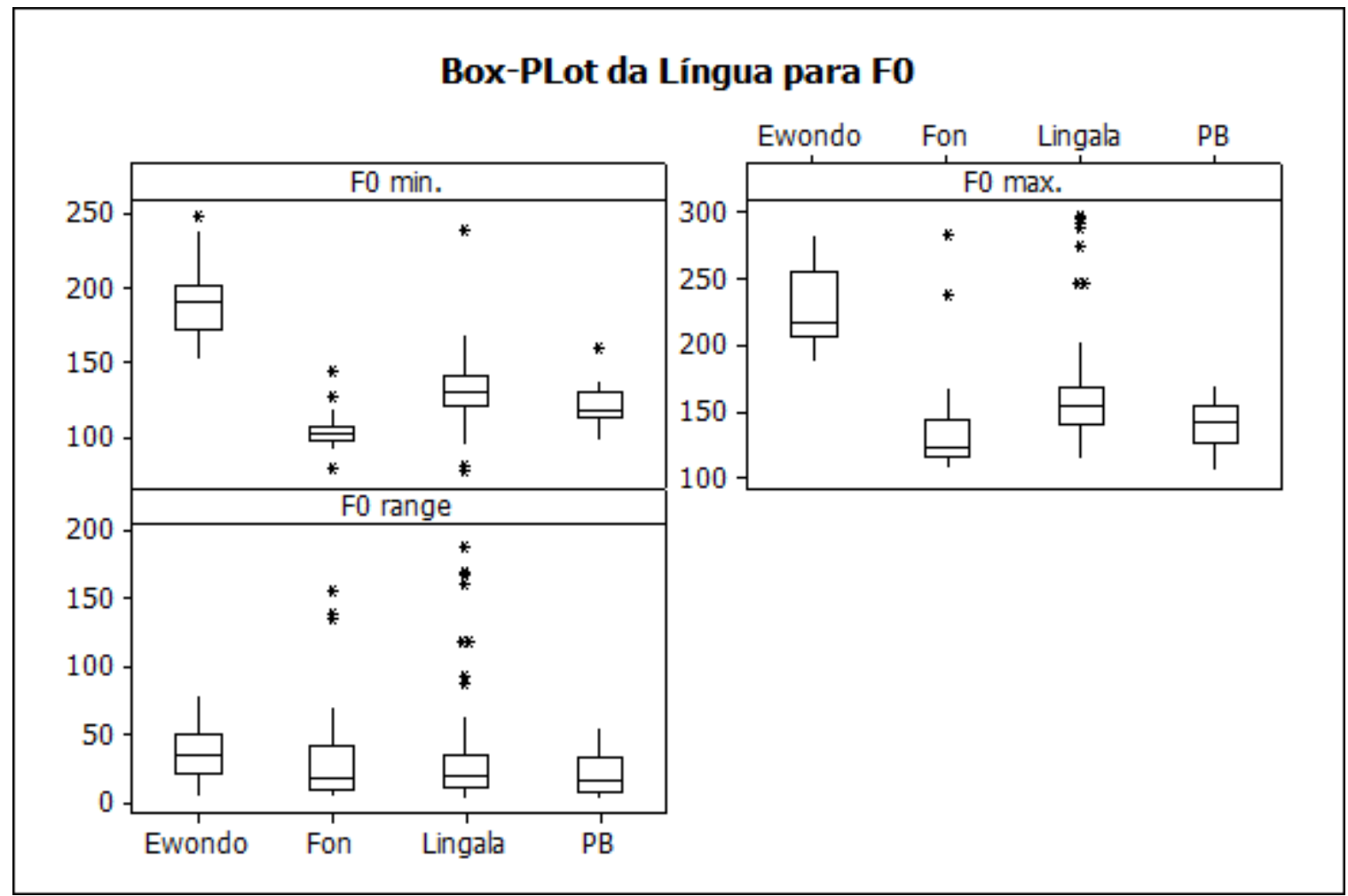

Figura 20: Gráficos box-plot para constatação do contraste dos valores de f0 entre os colaboradores por L1.

Quanto à comparação entre modalidades, a análise estatística evidenciou também poucas diferenças significativas de f0. A diferença mais relevante foi verificada entre a Declarativa III de média 19,3 em comparação com Interrogativa I com média 46,0 (p-valor 0,020),

\subsubsection{A notação entoacional: o sistema DaTo}

A análise da curva melódica pautou-se no sistema notacional DaTo (Dynamic Tones of Brazilian Portuguese). Criado por Lucente (2008;2012), o sistema segue pressupostos dinâmicos que descrevem amplamente a entoação do PB. É importante mencionar que outro sistema de notação entoacional já havia sido proposto, o ToBI, em inglês, Tones and Break Indices, (BECKMAN et al., 1994; SILVERMAN et al., 1992), entretanto, não sob uma perspectiva dinâmica que se adequasse ao PB.

$\mathrm{Na}$ análise embasada pelo sistema DaTo, o contorno da notação está diretamente relacionado ao movimento da curva entoacional em que a proeminência é marcada 
(LUCENTE, 2012). Nos dados desta pesquisa, a curva de f0 foi analisada em todos os pontos de proeminência das vogais tônicas, assim como, na proposta da notação, nas fronteiras de enunciados.

Foram analisados e rotulados 237 contornos. Para ilustrar a análise, foram escolhidas figuras que mostrassem, em primeiro lugar, a ocorrência dos contornos entoacionais e níveis de fronteiras presente nos dados. O primeiro contorno dinâmico, intitulado LH (rising), parte de uma posição mais baixa na sílaba pré-tônica e consegue alcançar seu pico ainda alinhado à vogal tônica.

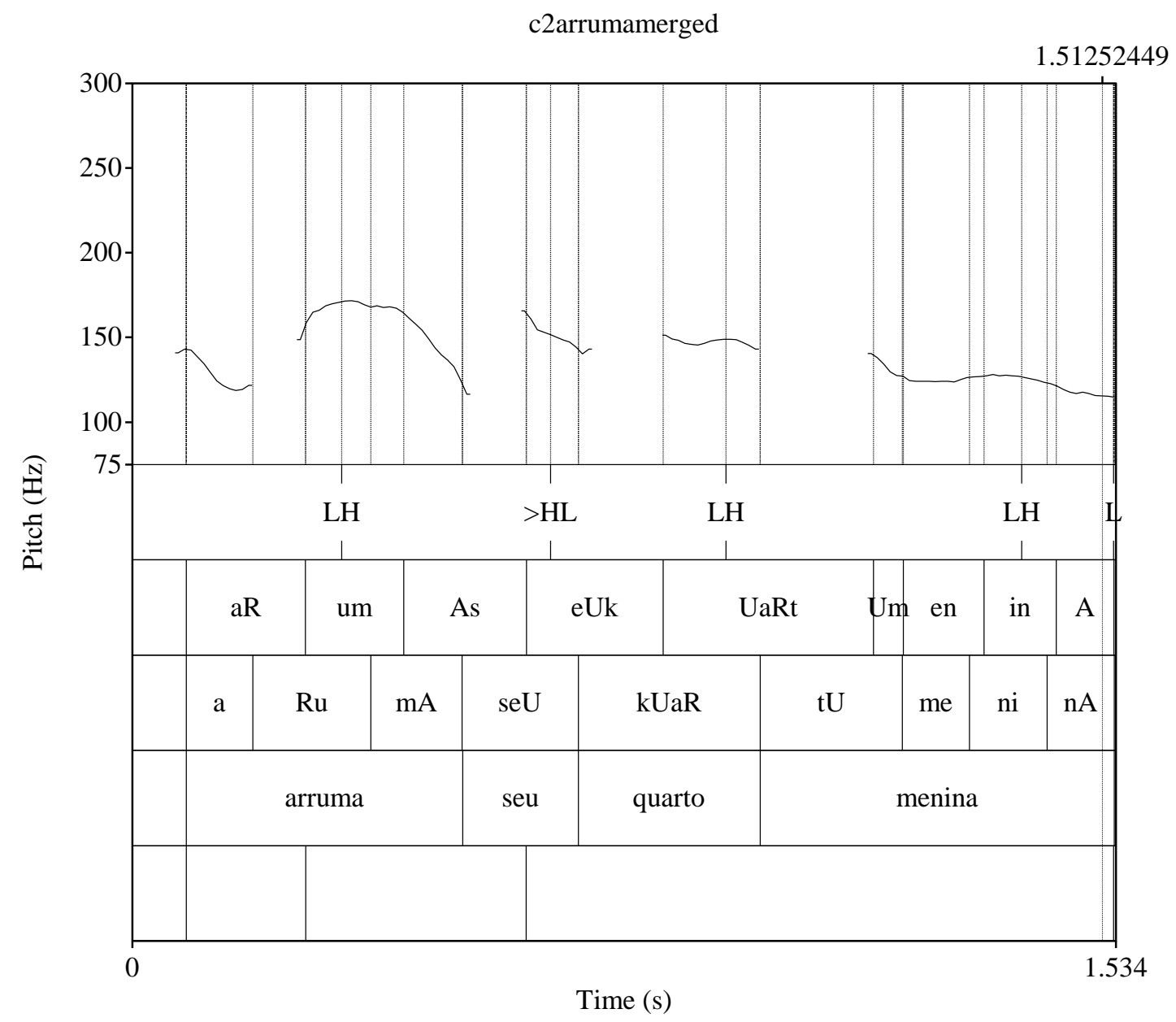

Figura 21: O contorno dinâmico LH no enunciado injuntivo "Arruma seu quarto, menina", produzido por $\mathrm{C} 2$

Na figura 21 há uma ilustração da ocorrência do contorno LH, muito recorrente no início dos enunciados produzidos pelos colaboradores em praticamente todas as modalidades: injutiva, declarativa e interrogativa. Observa-se na unidade VV [um] um contorno de subida que tem seu início da sílaba pretônica e que alcança seu pico alinhado à vogal tônica da palavra em foco. Há, posteriormente, uma descida do contorno na sílaba pós-tônica. O rótulo 
LH foi recorrente em 36,7\% dos contornos. Quanto à posição, 50\% dos contornos no início dos enunciados foi LH e 2,5\% também nas fronteiras finais de enunciados.

O segundo contorno dinâmico recorrente nos dados é intitulado por > LH (late-rising) no sistema notacional DaTo. Lucente (2012) indica que > LH é tão frequente quanto LH na marcação dos enunciados declarativos e interrogativos em PB, o que se pode reafirmar com o corpus analisado nesta tese.

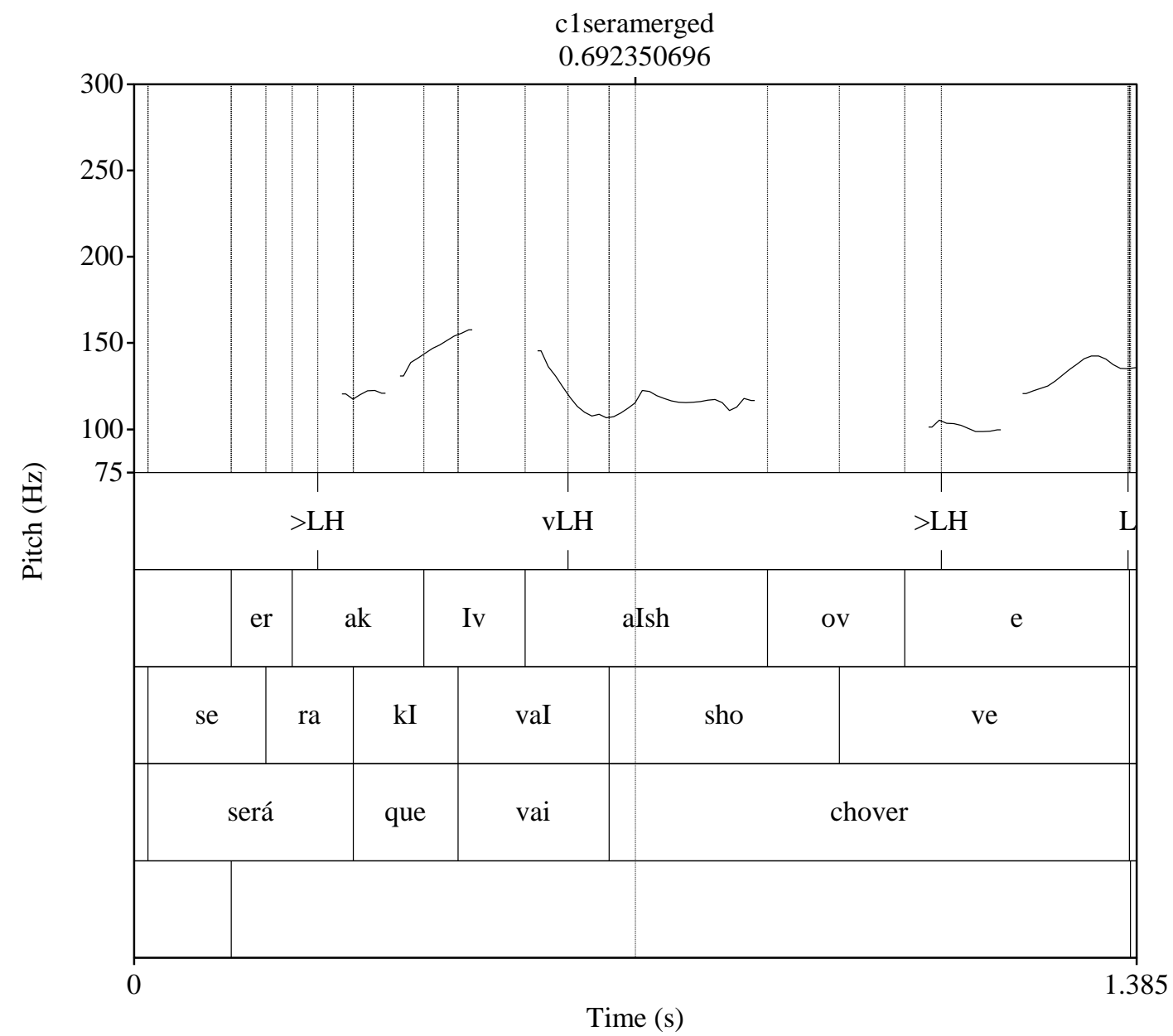

Figura 22: O contorno dinâmico >LH no enunciado interrogativo "será que vai chover?", produzido por $\mathrm{C} 1$

Na Figura 22, >LH está marcado em dois pontos nos picos que ocorrem com atraso no alinhamento à vogal tônica. Lucente (2012) aponta esse atraso como o resultado de uma pertubação no alinhamento de dois sistemas: o articulatório e o entoacional. Nos dados analisados, $23.2 \%$ dos rótulos foram > LH. Dos rótulos em início de enunciado, eles representam 37,5\%. Nas fronteiras finais não foram encontradas ocorrências desse contorno.

O terceiro contorno dinâmico presente nos dados se chama vLH (compressed rising) e marca ênfase como LH e >LH. 


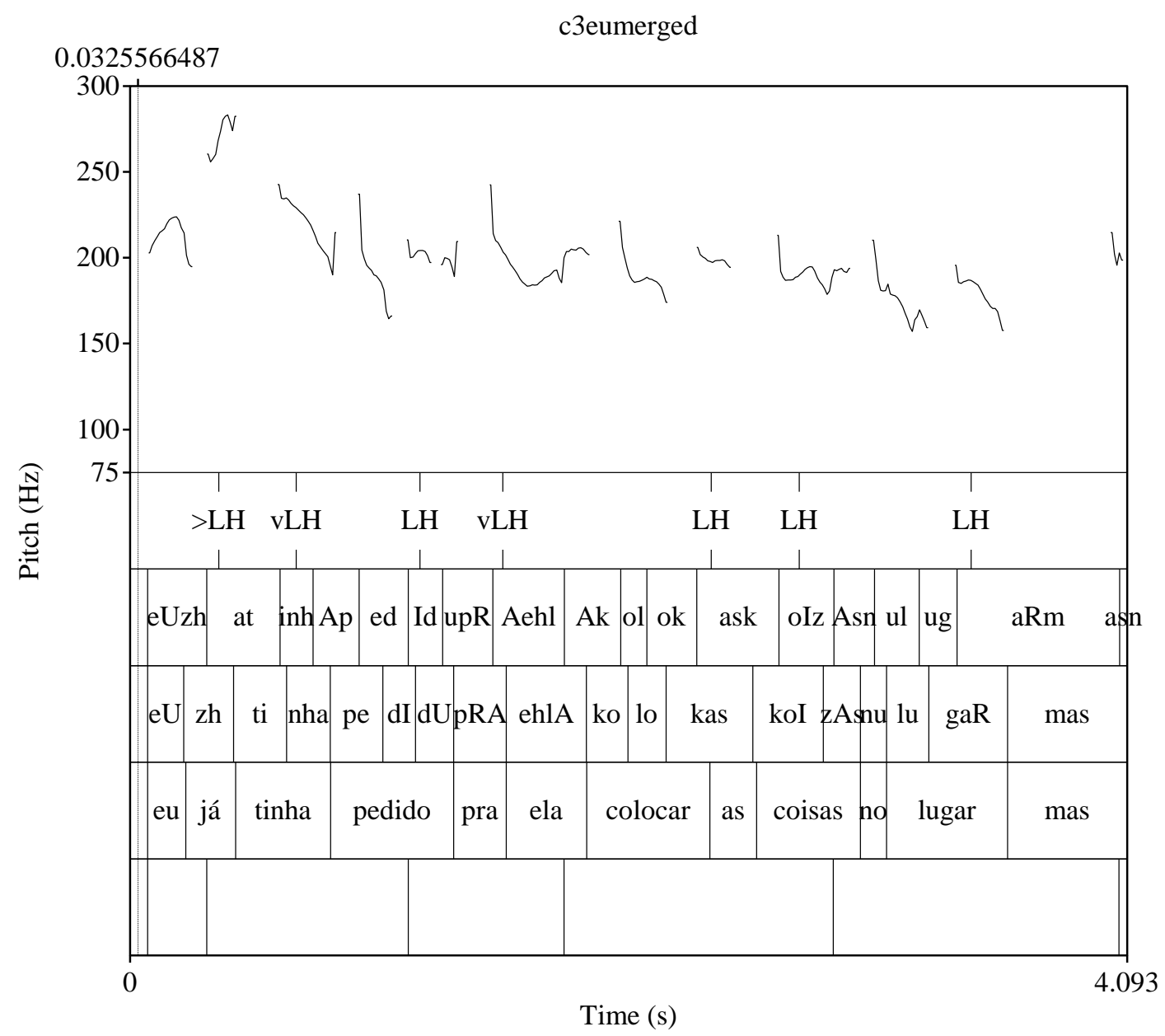

Figura 23: As ocorrências do contorno dinâmico vLH no enunciado interrogativo "eu já tinha pedido pra ela colocar as coisas no lugar, mas ela não me obedece", produzido por C3.

Lucente (2012) aponta que esse contorno acontece quando não há espaço ou ainda por uma impossibilidade fisiológica para que haja a produção de outro pico elevado, chamando-o, portanto, de LH comprimido. Na amostra de análise acima, o contorno vLH está na unidade VV [inh], entre duas consoantes oclusivas. O contorno vLH está presente em $16,4 \%$ dos enunciados. Nas ocorrências, observa-se que 7,5\% desses rótulos marcam fronteiras iniciais. Não há recorrências desse contorno em fronteiras finais.

O quarto contorno encontrado na análise de dados se intitula HL (falling) e é mais comum em fronteiras de enunciados ou perto delas, como se pode notar na Figura 24: 


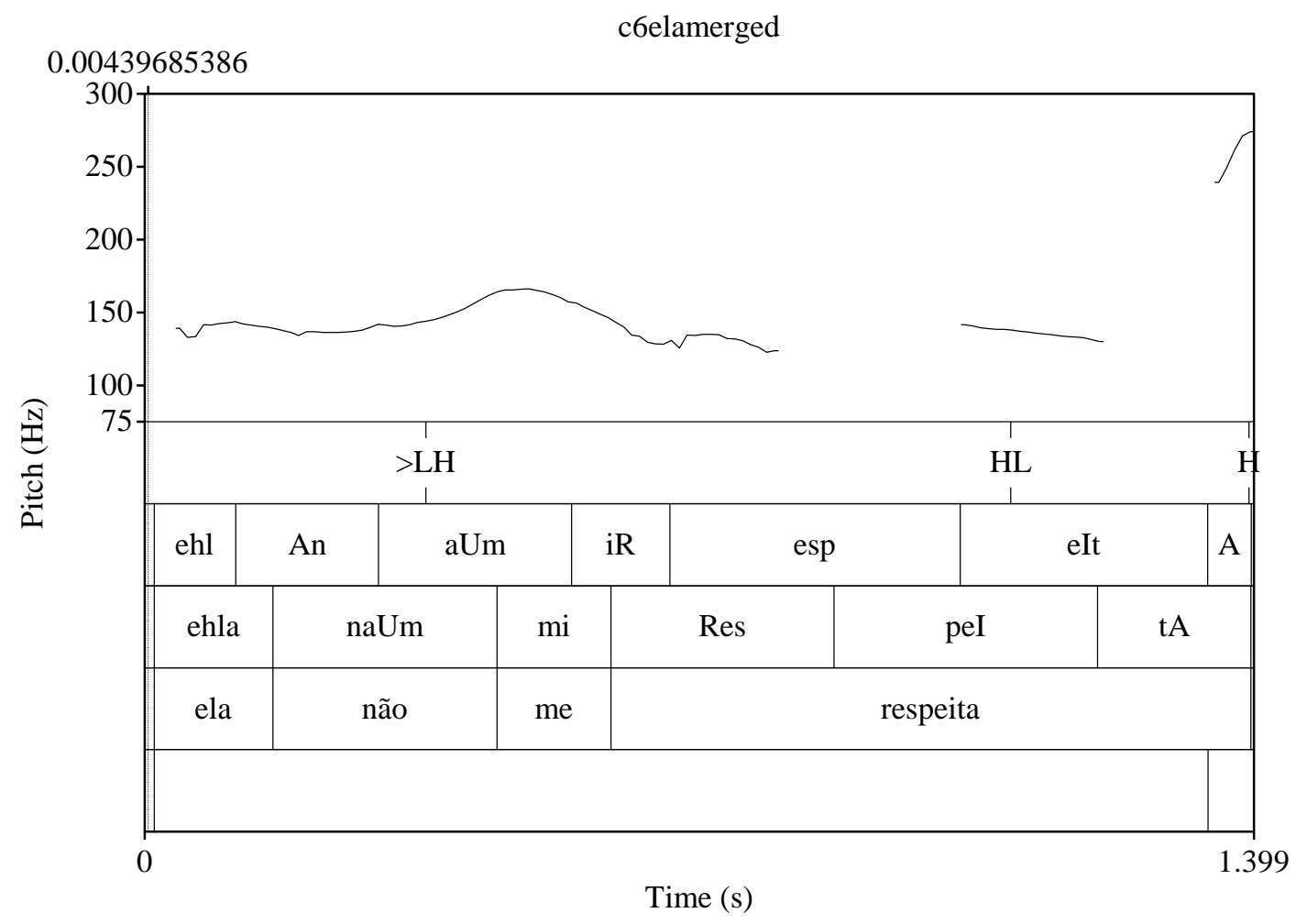

Figura 24: O contorno dinâmico HL no enunciado declarativo "ela não me respeita", produzido por C6.

Os contornos HL ocorrem quando f0 começa a subir na sílaba pretônica alinhada ao início da consoante, assim, o pico fica alinhado ao meio da vogal pretônica, havendo uma descida em seguida, que ocorre na transição com a sílaba tônica. Com frequência de 4,6\% nos dados desta pesquisa, o rótulo HL foi encontrado em 2,5\% dos inícios de enunciados, mas não teve ocorrências em fronteiras finais.

O quinto contorno recorrente nos dados é o >HL (late falling), que tem os mesmos movimentos de HL, contudo, em posição atrasada, como é possível notar na Figura 25: 


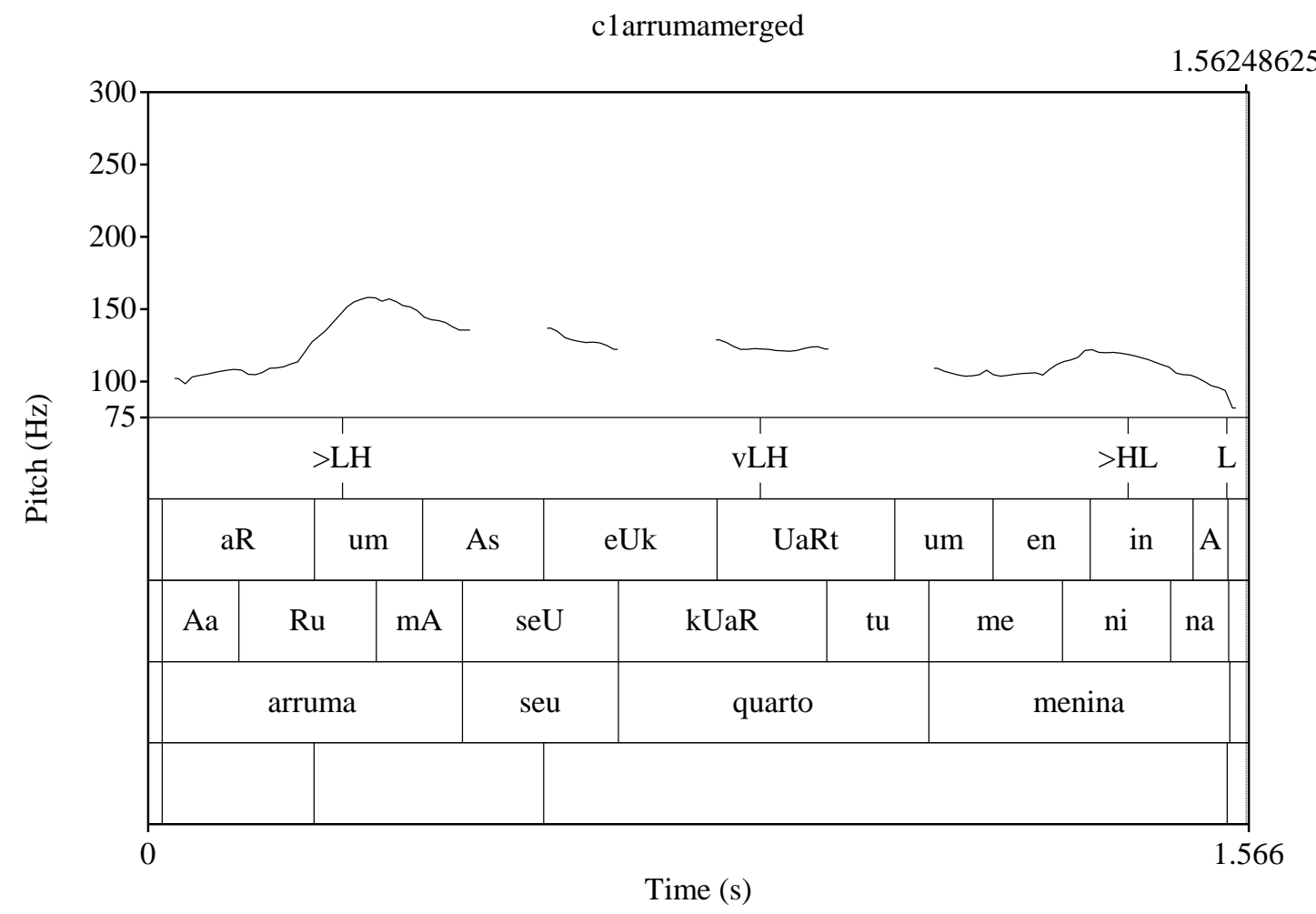

Figura 25: O contorno dinâmico >HL em um trecho do enunciado injuntivo "Arruma seu quarto, menina", produzido por $\mathrm{C} 1$.

Na unidade VV [in], pode-se notar o atraso no pico. A curva de f0 se alinha à vogal tônica, mas só alcança seu pico descendente na próxima unidade VV. Casos de contornos >HL não foram recorrentes nos dados, bem como Lucente (2012) aponta não serem muito recorrentes no PB. O contorno $>$ HL ocorreu em 2,1\% dos dados, sem nenhuma ocorrência em início ou fronteiras finais de enunciados.

O sistema notacional DaTo intitula os níveis de fronteira em H (alto) e L (baixo). Com relação a esses níveis, nos dados, o contorno $\mathrm{H}$ representa $3,7 \%$ dos rótulos, enquanto $\mathrm{L}$ representa 13\%. Como marcadores de fronteiras, L representa 75\% delas, contra 22,5 representadas por $\mathrm{H}$.

Os contornos HLH (falling-rising), vHL (compressed falling) e LHL (rising-falling) não foram encontrados nos dados analisados, nem nas produções dos colaboradores francófonos, nem de $\mathrm{C} 0$, o colaborador controle.

\subsubsection{A frequência dos rótulos do sistema DaTo por modalidade de enunciados}


Para prover uma análise entre as notações entoacionais dos colaboradores francófonos e de $\mathrm{C} 0$, descreveu-se a frequência dos rótulos por enunciado. Nas sentenças declarativas, o padrão encontrado foi o uso de fronteira $\mathrm{L}$ em todos os enunciados, seguidas necessariamente de um contorno HL. As fronteiras iniciais dos enunciados declarativos de C0 também foram marcadas por HL.

Em consonância com os contornos entoacionais de $\mathrm{C} 0$, a análise dos dados dos colaboradores francófonos evidenciou que, nos enunciados declarativos, 57,8\% dos contornos iniciais de fronteira foram LH e outros 36,8\%, >LH. Entretanto, não se pode considerar que uma frequência significativa de >LH apresente discrepância na comparação com os dados de $\mathrm{C} 0$, uma vez que esse contorno é bastante produtivo em enunciados declarativos de falantes do PB. Um dado curioso é que o contorno vLH está em 5,2\% dos contornos da modalidade declarativa, mas apenas para C5. Quanto às fronteiras finais, 100\% dos contornos foram L.

Para visualizar a semelhança dos contornos dos colaboradores francófonos ao de $\mathrm{C} 0$, o quadro abaixo indica, por meio de cores, o contraste de uma sentença declarativa.

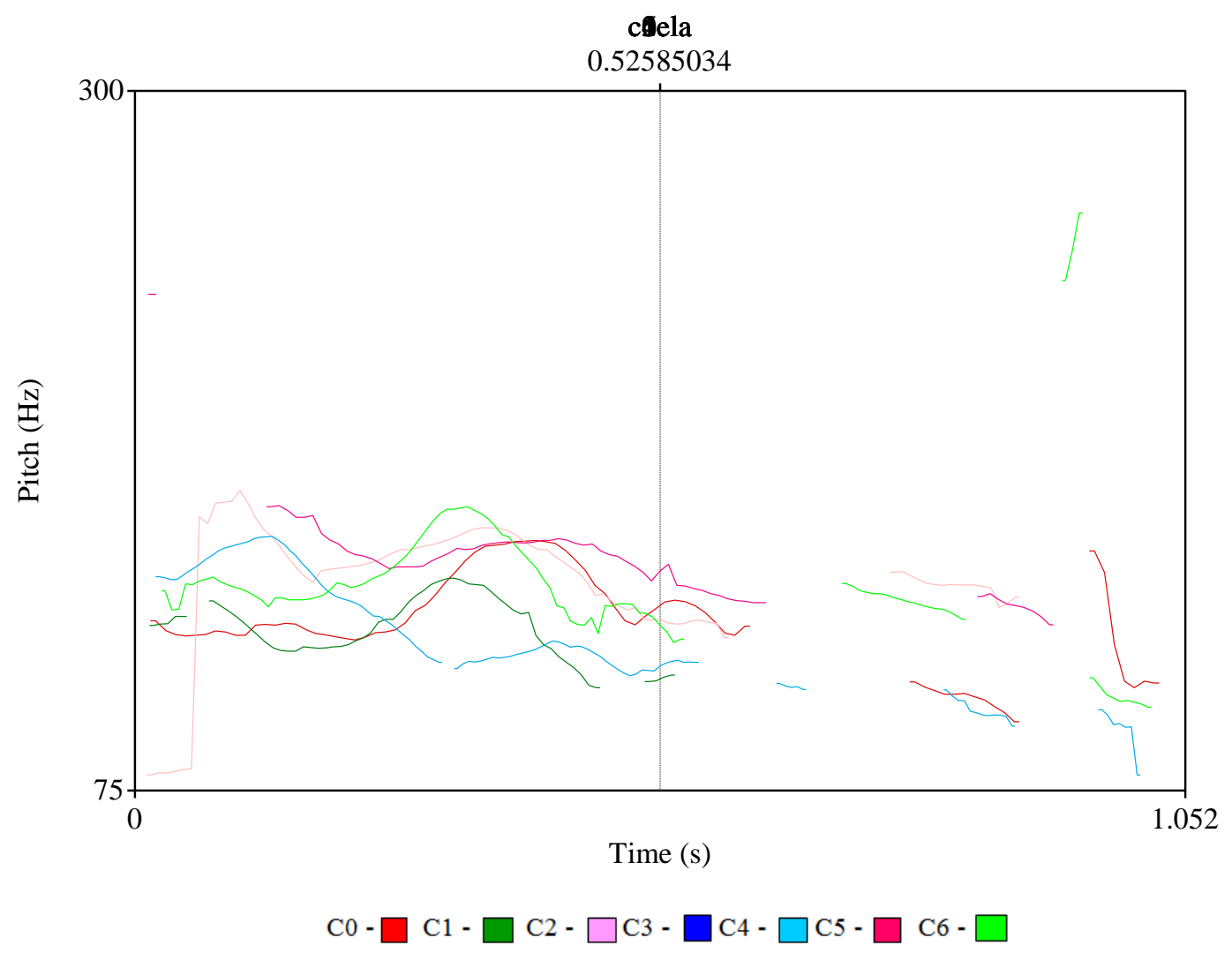

Figura 26: Comparativo entre as variações da frequência fundamental (f0) dos colaboradores no enunciado declarativo "Ela não me respeita". 
Na Figura 26, contata-se a semelhança dos contornos entre os colaboradores francófonos e C0 nas fronteiras do enunciado, assim como pode-se notar que, embora haja valores diferentes de $\mathrm{f} 0$, os contornos trilham para os mesmos picos de $\mathrm{C} 0$, não havendo discrepâncias significativas que possam, por exemplo, prejudicar a comunicação.

Para reafirmar a constatação, na Figura 27 também é possível encontrar similaridades em outro enunciado declarativo.

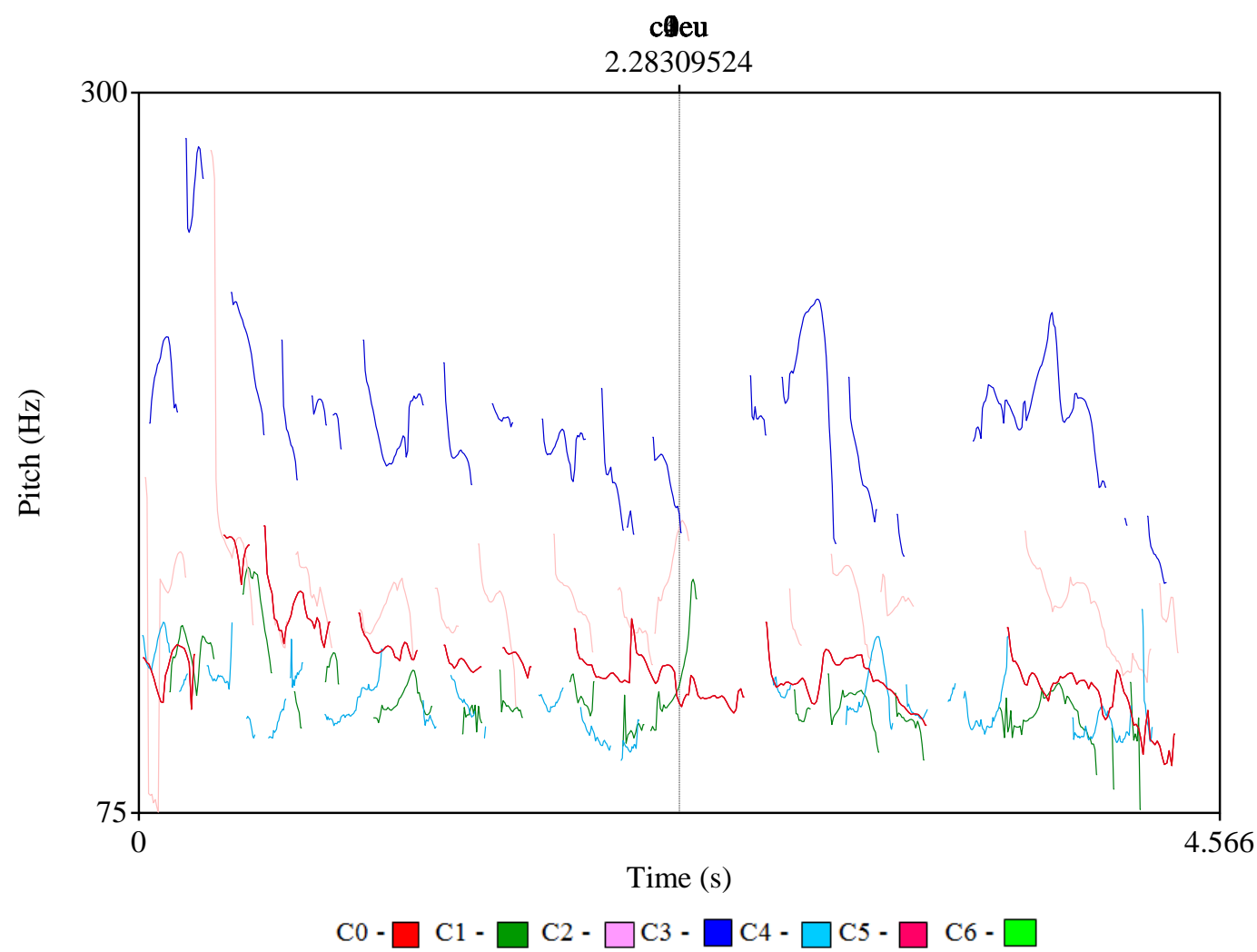

Figura 27: Comparativo entre as variações da frequência fundamental (f0) dos colaboradores no enunciado declarativo "Eu já tinha pedido pra ela colocar as coisas no lugar, mas não adianta, ela não me obedece".

$\mathrm{Na}$ Figura 27, pode-se observar as similaridades dos contornos de fronteira, marcados pelos rótulos $\mathrm{LH}$ e > LH no início, com movimento de descida do final dos enunciados, evidenciando o rótulo L.

Quanto aos enunciados interrogativos, observa-se que 57,1\% das fronteiras de início foram marcadas pelo contorno $\mathrm{LH}$, e $28,5 \%$, pelo $>\mathrm{LH}$. O contorno $\mathrm{vLH}$ apresentou ocorrência em $14.2 \%$ desses enunciados e ocorreu apenas nos dados de C0. Dessa forma, $100 \%$ dos colaboradores francófonos produziram enunciados com proeminência de rótulo LH 
ou > LH no início dos enunciados interrogativos e todos os colaboradores apresentaram contornos ascendentes nas fronteiras iniciais, como é possível notar na Figura 28:

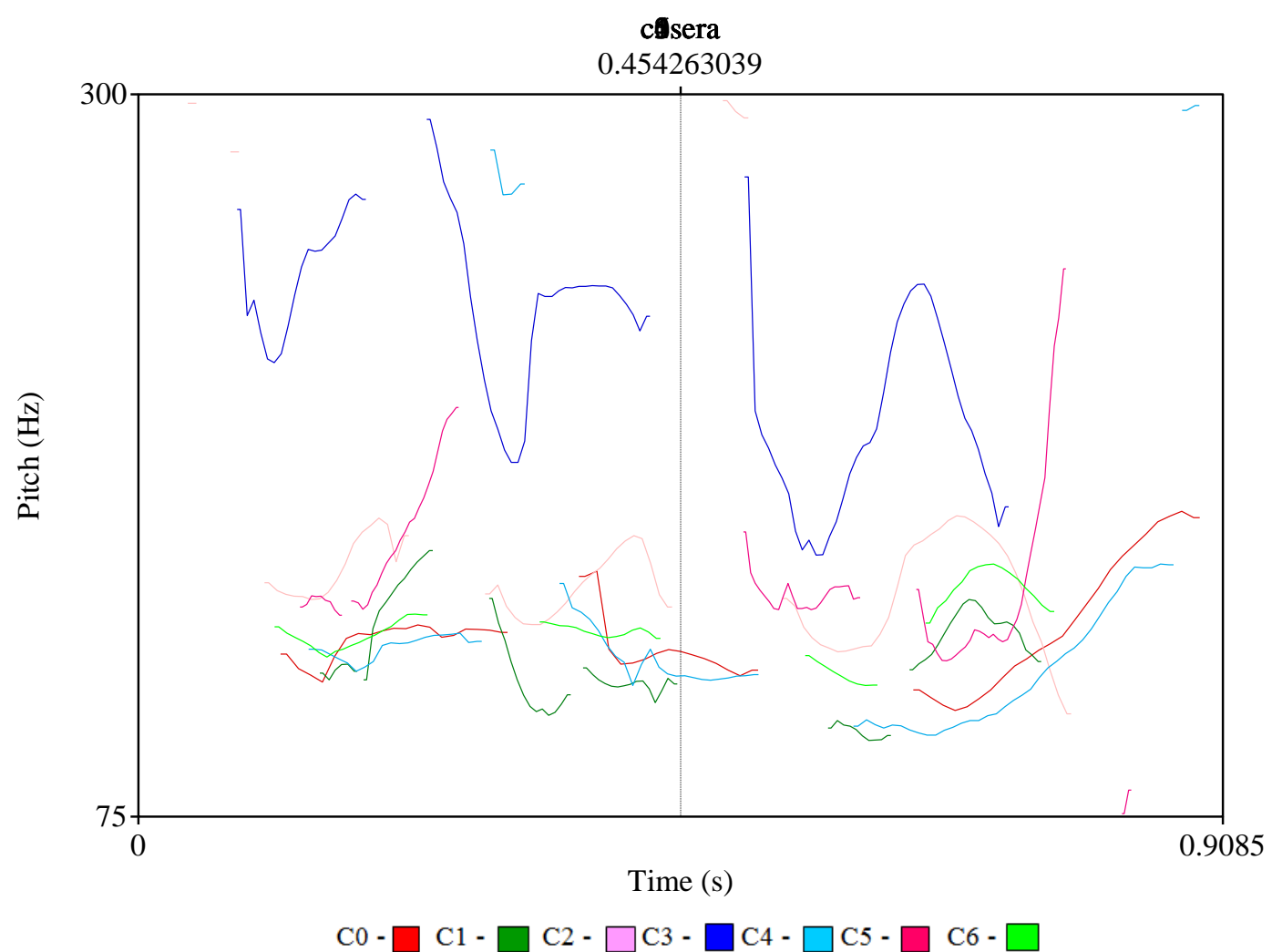

Figura 28: Comparativo entre as variações da frequência fundamental (f0) dos colaboradores no enunciado interrogativo "Será que vai chover?".

Apesar da similaridade dos contornos nas fronteiras iniciais, há discrepância significativa nas fronteiras finais. Para os enunciados interrogativos, $50 \%$ dos dados dos colaboradores apresentou proeminência $\mathrm{H}$ para o final e outros $50 \%$, L. Entretanto, é necessário apontar que dos enunciados interrogativos produzidos por $\mathrm{C} 0,100 \%$ apresentaram fronteira ascendente H. O contraste também pode ser visto na Figura 29, em outra amostra: 


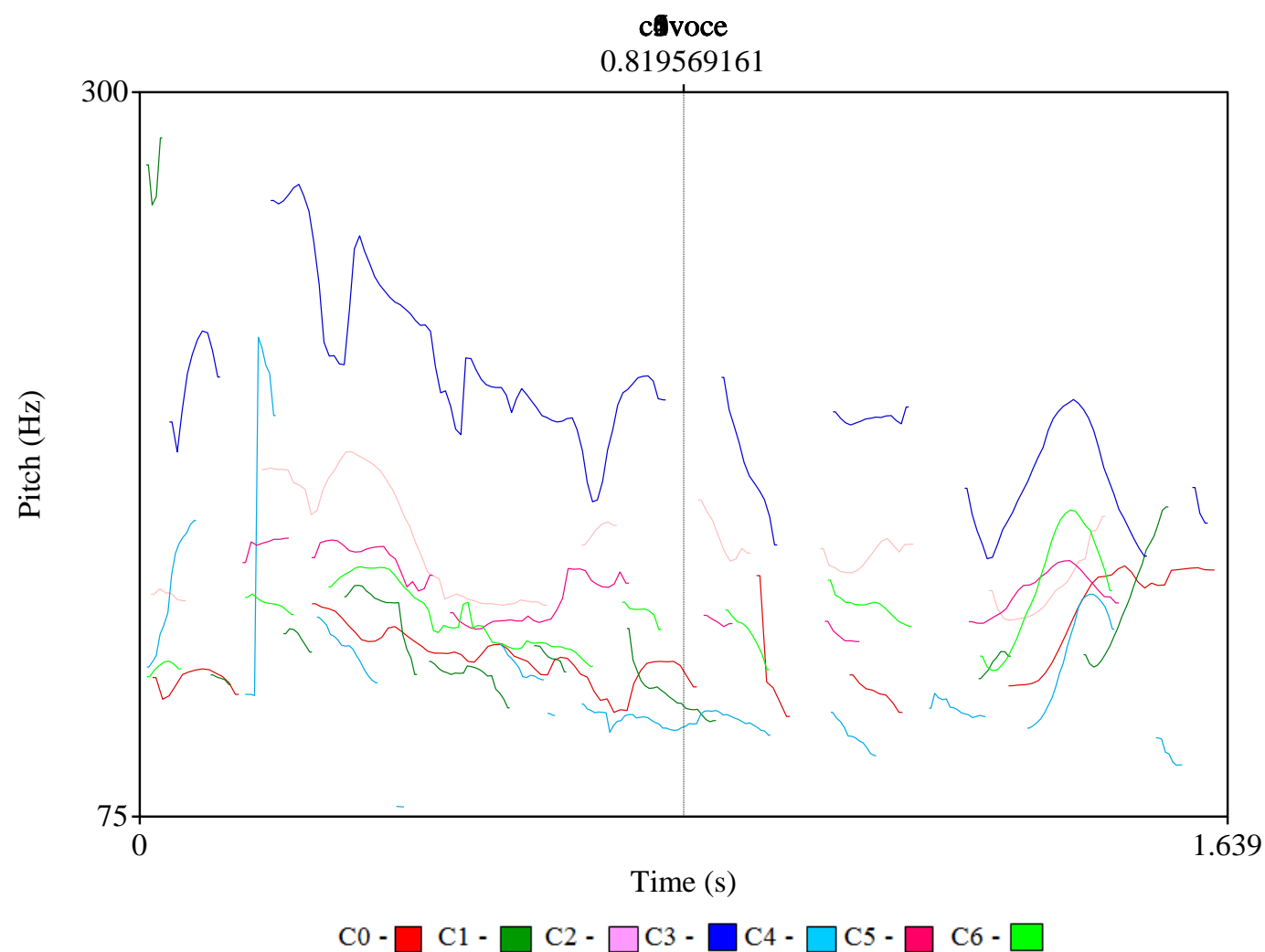

Figura 29: Comparativo entre as variações da frequência fundamental (f0) dos colaboradores no enunciado interrogativo "Você já organizou seu quarto hoje?".

De maneira geral, 58,3\% dos colaboradores francófonos apresentaram fronteira final $\mathrm{L}$, o que destoa do padrão do $\mathrm{PB}$, que marca as fronteiras finais de enunciados interrogativos com proeminência H. A ocorrência esteve presente em, pelo menos, uma sentença interrogativa de cada colaborador francófono, o que aponta para a não internalização da estrutura entoacional em enunciados interrogativos em PB.

A última modalidade analisada foi a injuntiva. Nesses enunciados, o contorno LH foi encontrado no início de 44,8\% das sentenças e > LH, nos outros 55,2\%. Nos dados de C0, o contorno LH foi encontrado em $100 \%$ dos enunciados nas fronteiras iniciais. Nas fronteiras finais, o rótulo $\mathrm{L}$ foi presente em $71,4 \%$ dos dados, enquanto $\mathrm{H}$ esteve em 14,2\%. Curiosamente, o contorno LH também foi encontrado em fronteiras, representando outros 14,1\% dos rótulos. Na Figura 30, é possível ver uma comparação da amostra: 


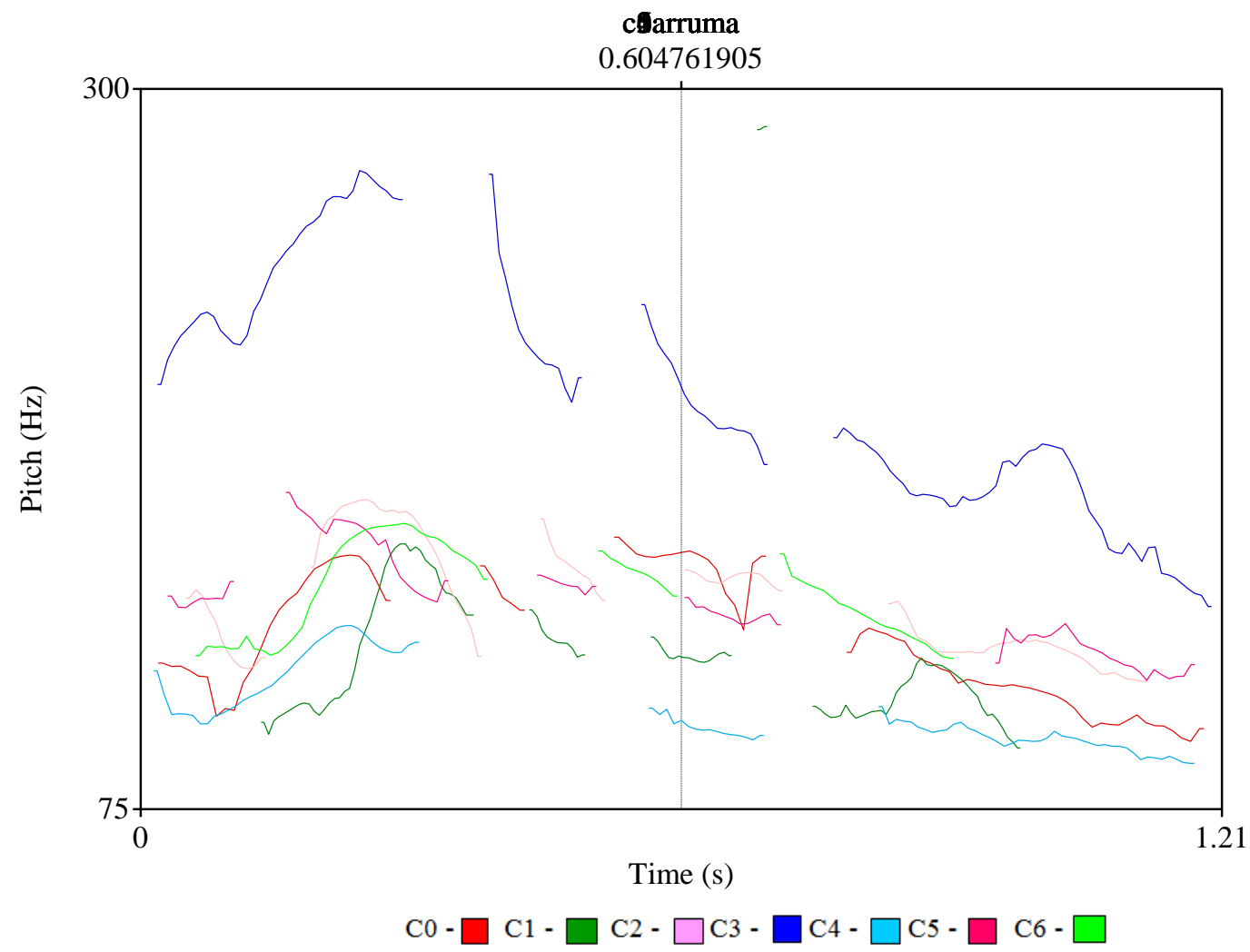

Figura 30: Comparativo entre as variações da frequência fundamental (f0) dos colaboradores no enunciado injuntivo "Arruma seu quarto, menina".

Na Figura 30, observa-se a configuração da curva de fo dos colaboradores e evidencia-se uma consonância significativa. As fronteiras iniciais apresentam movimentos de subida e as finais, de descida. Nos dados, o rótulo $\mathrm{H}$ em final só foi encontrado em enunciados produzidos por $\mathrm{C} 5$, integrante do Grupo A, o de maior tempo de imersão. Ainda assim, o rótulo $\mathrm{H}$ não foi frequente em todos os dados desse colaborador. Dessa forma, afirma-se que, por meio da análise dos enunciados injuntivos, os colaboradores francófonos apresentam desempenho entoacional similar a $\mathrm{C} 0$, não sendo esta modalidade um impeditivo no processo de aquisição da entoação e do ritmo.

A análise percentual da frequência dos rótulos da notação entoacional permitiu constatar que há discrepâncias significativas de entoação apenas nos enunciados interrogativos produzidos pelos colaboradores francófonos, que seguiram, na maioria dos dados, um padrão rítmico distinto do PB para a produção de perguntas, o que pode gerar problemas de compreensão com o interlocutor. 


\section{CONCLUSÃO}

O capítulo final desta tese apresenta um diálogo com os objetivos propostos para a realização do trabalho, relata as perspectivas futuras para os estudos relacionados ao tema e disserta sobre a aplicabilidade das reflexões para o ensino do ritmo e da entoação.

\subsection{As respostas aos questionamentos motivadores ao tema}

Observar a aquisição da linguagem como um sistema complexo e dinâmico é abrir caminhos para pensar nesse processo também de maneira não linear. Para os sujeitos desta pesquisa, em especial, há fatores envolvidos que muitas vezes destoam de um aprendiz de PBSL: o nível social-cultural, a tensão do requisito de exame de proficiência, a ideia de nova adaptação à realidade depois da aprovação e, com base neste estudo, as interferências diretas de suas línguas maternas na aquisição do ritmo e da entoação do PB. Sabe-se, contudo, que o processo de aquisição é um continuum. Os sujeitos interagem e, a cada dia, há mudanças no sistema linguístico em direção ao seu desenvolvimento.

A iniciativa deste trabalho surgiu do interesse pelas particularidades da pronúncia nas produções de aprendizes francófonos do PB. No início desses estudos, não se esperava, no entanto, que fosse possível encontrar respostas no nível suprassegmental. Os objetivos da pesquisa foram se refinando até que a reposta fosse encontrada justamente na competência multilinguística dos aprendizes africanos.

A divisão dos colaboradores desta pesquisa em grupos objetivou identificar se as línguas maternas desses aprendizes seriam fatores determinantes quando comparadas entre si, ou, ainda, se havia distinção entre a produção dos enunciados por modalidades e entre aprendizes por tempo de imersão. Elaborou-se um estudo descritivo, primeiramente, sobre a família linguística que abrangia as línguas maternas desses aprendizes que, posteriormente, tornaram-se colaboradores ao estudo. Conhecer o mosaico das línguas africanas proporcionou o entendimento da influência das línguas tonais diretamente na aquisição do PB.

Diferentemente de um falante nativo, os colaboradores francófonos apresentaram uma característica muito particular que os diferencia dos demais aprendizes: a duração ampla das unidades silábicas. A unidade abordada neste trabalho foi a $\mathrm{VV}$, que parte do onset de 
uma vogal até o onset da vogal seguinte. Trabalhos anteriores já haviam evidenciado o papel das unidades VV na estrutura rítmica do PB e essas pesquisas contribuíram imensamente para traçar uma comparação entre as produções de um falante nativo e de falantes de PBSL.

Conhecer o padrão rítmico das línguas dos colaboradores também foi importante. Em muitas de suas línguas, diferentemente do PB, a marcação da tonicidade não está ligada pelo alongamento das unidades silábicas, sendo comum que as sílabas tenham durações mais uniformes. Foi possível identificar e contrastar estatisticamente a diferença na duração (em milissegundos) das unidades VV entre os colaboradores francófonos e o controle, promovendo contrastes que abarcaram seu tempo de imersão, sua língua materna e também a modalidade dos enunciados produzidos.

Embora a duração das unidades VV tenha apresentado grandes diferenças entre colaboradores francófonos e controle, por meio da notação entoacional, sob a visão do sistema DaTo, foi possível constatar que os colaboradores alcançaram proeminências muito semelhantes àquelas do colaborador controle e, consequentemente, rótulos notacionais. Entretanto, um fato curioso foi que o tempo de imersão não foi fator determinante para que os contornos dos colaboradores francófonos se aproximassem do colaborador controle, evidenciando que aptidões individuais e até mesmo línguas maternas distintas são fatores que influenciam a aquisição rítmica mais diretamente.

Constatou-se que a duração das unidades VV é que indicam a grande discrepância entre os falantes do PB e, quanto à modalidade, é no enunciado interrogativo que está a principal distinção do PB: na fronteira final com contorno descendente, ao invés de ascendente.

Essas características estão presentes nas produções de todos os colaboradores, independentemente do seu tempo de imersão. A frequência desses fenômenos abre os caminhos para a presença de fossilização na estrutura rítmica do sistema adquirido. Observando a língua como um sistema dinâmico, pode-se notar a dificuldade na produção e na interpretação da entoação como pontos que requeiram muita energia para o aperfeiçoamento deste campo da aquisição fonológica.

Com base no SLM (FLEGE, 2005), a aprendizagem da fala permanece intacta durante a vida dos falantes, contudo, os efeitos da idade aparecem pela forma como os sistemas fonéticos da L1 e L2 interagem. Dessa forma, é preciso ajudar esses sujeitos a aperfeiçoarem suas categorias fonéticas usadas na percepção e na produção da L1 para a L2. Assim, sons idênticos e diferentes podem ser percebidos e, tratando-se de diferenças acústicas, o tratamento das dificuldades pode ganhar mais enfoque. 
Para que os sujeitos melhorem sua percepção e produção entoatória, é preciso pensar em estratégias de criação de novas categorias fonéticas para o PB, por sua estrutura rítmica diferenciada das línguas da subsubfamília bantu.

\subsection{Perspectivas para futuras pesquisas embasadas na aquisição do ritmo e aplicabilidade da pesquisa}

A elaboração deste trabalho trouxe outras perguntas para os estudos linguísticos. Embora houvesse coletado dados em língua francesa, a pesquisadora decidiu trabalhar apenas com as produções dos colaboradores em PB. Além disso, para segmentar e analisar os dados no programa de análise, a qualidade das gravações para esse propósito deveria ser alta, o que motivou a coleta de dados mais controlada. Será enriquecedor para a pesquisa linguística buscar análises que envolvam também a fala espontânea, assim, espera-se aplicar a metodologia deste trabalho a novos dados, como também contar com mais colaboradores. A língua materna dos aprendizes também é de grande interesse para a pesquisadora. Dessa forma, espera-se contribuir com discussões acerca da aquisição do ritmo do PB por falantes de outras línguas, especialmente, línguas que tenham estrutura rítmica muito próxima ou muito distante do PB.

Ao aprender uma segunda língua, o desenvolvimento da habilidade oral é um dos maiores desafios tanto para os aprendizes quanto para o professor. As dificuldades voltadas para a habilidade oral podem ser resultantes de diversos fatores, como visto neste trabalho. Chegar à pronúncia ideal não é um processo simples, ainda que tratemos de L1 e L2 semelhantes. A aquisição da pronúncia e do ritmo se torna um desafio quando, até mesmo nos estágios mais avançados de aprendizagem da L2, o sujeito continua com dificuldades, prejudicando sua produção oral e alterando sons. Isso também pôde ser comprovado com base na análise da duração das unidades VV. Alguns aprendizes, ainda que tivessem mais tempo de imersão que outros, possuíam interferências muito marcadas.

Para ensinar entoação, é necessário fazer uma abordagem adequada das teorias fonológicas. Atualmente, para ensinar as vogais e consoantes, é usada a análise fonológica segmental linear por meio do Alfabeto Fonético Internacional. O método citado anteriormente implementa o ensino da fonética, levando o aluno compreender que existem consoantes e 
vogais como traços segmentais, não levando à reflexão de que existem outros traços sonoros que desafiam o modelo.

O mais árduo é trazer ao entendimento desses alunos as dimensões da variação entoacional que caracterizam suas línguas maternas e que os mesmos contornos podem ter funções distintas em outras línguas, já que essas noções têm ligação com a estrutura sonora, o que não é visto nos estudos de ensino de prosódia.

A maioria dos aspectos entoacionais está ligada a conceitos prosódicos como o acento, a sílaba e a o enunciado entoacional, o que já traz a eles uma dificuldade de caracterização. Entender a noção de pitch, por exemplo, exige o entendimento de que há unidades prosódicas como a sílaba e a frase entoacional. Na mesma maneira, não é possível explorar o pitch sem fazer uma ligação aos acentos.

Não é viável fazer a análise entoacional de uma língua sem resolver a questão da prosódia. Por isso, os aprendizes precisam desenvolver a habilidade de identificar os constituintes prosódicos usados pelos falantes nativos. Dessa forma, esses sujeitos poderão estruturar os traços entoacionais.

Atualmente, os computadores são aliados para a análise de processos fonológicos e concomitantemente para o ensino de segunda língua. Os softwares apresentam a possibilidade de visualizar a frequência fundamental, a duração e a intensidade dos sons, facilitando aos professores o entendimento das análises de padrões de entoação, ritmo e outras características fonéticas.

Um bom aliado no processo de aquisição do ritmo é o PRAAT. Os estudantes podem fazer gravações individuais e levarem para a sala de aula para que o professor mostre a variação de f0, sem grandes explicações de cunho científico, mas propondo que os contornos entoacionais se aproximem daqueles produzidos pelos falantes nativos.

A expectativa é que as discussões neste trabalho sirvam de insumo para a produção de materiais voltados para a aquisição do ritmo do PB, campo novo e em processo de ascensão. 


\section{REFERÊNCIAS}

ABAURRE, M. B. M. Fonologia e Fonética. Guimarães, E. e Zoppi-Fontana, M. (orgs.), Introdução às Ciências da Linguagem: a Palavra e a Frase. Campinas: Pontes, 2006.

ABERCROMBIE, D. Teaching pronunciation. In: BROWN, A. (Org.) Teaching English pronunciation: A book of readings. New York: Routledge, 1991.

ANGENOT, G. L.; AMARAL, G.G. Classificação tipológica e genealógica das línguas africanas. Rondônia: UFR, 2009.

ARANTES, P. Collect formants.praat, v. 0.11 alpha, 2011.

BARBOSA, P. A. Elementos para uma tipologia do ritmo (linguístico) da fala à luz de um modelo de osciladores acoplados. Cógnito - Cadernos Romênicos em Ciência Cognitiva, v. 2, n. 1, 2004, p. 31-58.

BARBOSA, P. A. Incursões em torno do ritmo da fala. Campinas: Pontes/Fapesp. 2006.

Prosódia. Enciclopédia Virtual de Psicolinguística, 2008. Disponível em <http://wikipsicolinguistica.org $>$. Acesso em 15 de julho de 2013.

BASTIN, Y. Les langues bantoues. In: BARRETEAU, D. (Org) 1nventaire des Études Linguistiques, pp. 123-185. Paris: Conseil International de la Langue Française, 1978, p. 123-185.

BECKMAN, M. E. On blending and the mora. Papers in Laboratory Phonology, v. 4, 1995, p. $157-167$.

BISOL, Leda. Introdução a estudos de fonologia do português brasileiro. 5 ed. Porto Alegre: EDIPUCRS, 2010.

BLEEK, W. A Comparative Grammar of South African Languages. Westmead: England: Gregg International, 1971.

BLOOMFIELD, L. Language. New York: Henry Holt and Company, 1933. 
BOERSMA, P.; WEENINK, D. (2011). PRAAT: doing phonetics by computer (versão 5.2.25) (programa de computador), acessado em 22 de outubro de 2014 em http://www.praat.org.

BOLINGER, D. Intonation. Harmondsworth: Penguin, 1972.

BROWMAN, C. P.; GOLDSTEIN, L. Dynamics and articulatory phonology. In: T. van Gelder e B. Port (Orgs.) Mind as motion. Cambridge: MIT Press, 1995, p. 175-193.

BROWN, H. D. Principles of language learning and teaching. 4 ed. Londres: Pearson Education, 2000.

BYBEE, J. Phonology and language use. Cambridge: Cambridge University Press, 2001.

CAGLIARI, L. C. Elementos de fonética do português brasileiro. Tese (livre-docência) Unicamp, Campinas, 1981.

CAGLIARI, L. C. Análise fonológica: Introdução à teoria e à pratica com especial destaque para o modelo fonêmico. São Paulo: Mercado das Letras, 2002.

CALLOU, D.; LEITE, Y. Iniciação à fonética e à fonologia. 10. ed. Rio de Janeiro: Jorge Zahar, 2005.

CAMARA JÚNIOR, J. M. Estrutura da Língua Portuguesa. 40. ed. Petrópolis: Vozes, 2007.

CHOMSKY, N. Aspects of the theory of syntax. Cambridge, MA: MIT Press, 1965.

CHOMSKY, N. Knowledge of language: its nature, origin and use. New York: Praeger, 1986.

$\mathrm{N}$. New horizons in the study of language and mind. Cambridge: Cambridge University Press, 1997.

CHOMSKY, N.; HALLE, M. The sound pattern of English. Nova Iorque, Evanston e Londres: Harper and Row, Publishers, 1968. 
CLARK, J; YALLOP, C. An introduction to phonetics and phonology. Oxford: Blackwell, 1995.

COOK, V. J. Competence and multi-competence. In: BROWN, G.; MALMKJAER, K; WILliAMS, J. (Orgs.) Performance and competence in second language acquisition. Cambridge: Cambridge University Press, 1996.

COOK, V. Linguistics and second language acquisition. Londres: Macmillan, 1993.

CORDER, S. P. Error Analysis: Perspectives on second language acquisition. Londres: Longman, 1974.

CORDER, S. P. The significance of learners' errors. International Review of Applied Linguistics, v. 5, 1967, p. 160-170.

COUTO, H. H. Ecolinguística: estudo das relações entre língua e meio ambiente. Brasília: Thesaurus Editora, 2007.

CRISTÓFARO-SILVA, T. Descartando fonemas: a representação mental da fonologia de uso. In: HORA, D.; COLLISCHONN, G. Teoria linguística: fonologia e outros temas. João Pessoa: Editora Universitária, 2003.

CRISTÓFARO-SILVA, T. Fonética e fonologia: perspectivas complementares. Estudos das Língua(gem), v. 3, p. 25-40, 2006 b.

. O Ensino de Pronúncia na Aula de Língua Estrangeira. In: FONSECASILVA, M. C.; PACHECO, V.; LESSA-DE-OLIVEIRA, A. S. C. Em torno da língua(gem): questões e análises. Vitória da Conquista: Edições UESB, 2007.

CRYSTAL, D. Dicionário de Linguística e Fonética. Rio de Janeiro: Jorge Zahar Editor, 1985.

CRYSTAL, D. The Cambridge encyclopedia of language. 3 ed. Nova Iorque, Cambridge University Press, 2010.

CRYSTAL, D.The language revolution. Cambridge: Polity Press, 2004. 
DE BOT, K.; MAKONI, S. Language and aging in multilingual contexts. Toronto: Multilingual Matters LTD, 2005.

ELLIS, N. Emergentism, connectionism and language learning, Language Learning, v. 48, n. 4, p. 631-664, 1998.

ELLIS, N. The study of second language acquisition. 2 ed. Oxford: Oxford University Press, 2008.

ELMAN, J. L.; BATES, E. A.; JOHNSON, M. H.; SMITH, A. K.; PARISI, D.; PLUNKETT, K. Rethinking innateness: A connectionist perspective on development. Cambridge: The MIT Press, 1996.

ERVIN, S.; OSGOOD, C. Psycholinguistics: A survey of theory and research problems. In: C. Osgood e T. Seboek (Orgs.), Psycholinguistics (pp. 139-146). Baltimore, MA: Waverly Press, 1954.

ESCUDERO, P. The linguistic perception of SIMILAR L2 sounds. In: Phonology in perception. Berlin: Mounton de Gruyter, 2009, cap. 5, p. 151-190.

FAGE, J. D. Historiografia Africana. São Paulo: Ática, 1981.

FLEGE, J. E. Second Language Speech Learning Theory, Findings, and Problems. In: STRANGE, W. (Org) Speech Perception and Linguistic Experience: Issues in CrossLanguage Research. Timonium: York Press, 1995.

FLEGE, J. E. The Phonological Basis of Foreign Accent: A Hypothesis. In: Tesol Quaterly, v. 14, 1981.

FLEGE, J. E.; SCHIRRU, C.; MACKAY I. R. A. Interaction between the native second language phonetic subsystems. Speech Communication, v. 40, 2003, p. 467-491.

FLEGE, J. E.; WALLEY, A. C. Effect of lexical status on children's and adult's perception of native and non-native vowels. Journal of Phonetics, v. 27, 1999, p. 307-332.

FLICK, U. Introdução à Pesquisa Qualitativa. Porto Alegre: Artmed, 1995. 
FRIES, C.C. Teaching and learning English as a foreign language. Ann Arbor: University of Michigan Press, 1945.

FRY, D. B. Duration and intensity as physical correlates of linguistic stress. Journal of the Acoustical Society of America, 1955.

GASS, S. Integrating research areas: a framework for second language studies. Applied Linguistics, v. 9, 1988, p. 198-217.

GASS, S. M.; SELINKER, L. Second language acquisition: an introductory course. 3 ed. Nova Iorque: Routledge, 2008.

GASS, S.; SELINKER, L. Language Transfer in Language Learning. Rowley: Newbury House, 1983.

GOLDSMITH, J. A. Autosegmental and metric phonology. Oxford e Cambridge: Basil Blackwell, 1990.

GOLDSMITH, J. A. Phonological Theory. In: GOLDSMITH, John A. The Handbook of Phonological Theory. Cambridge, Massachuset: Blackwell, 1995.

GREENBERG, J. H. Universals of Language. Cambridge: MIT Press, 1963.

GREENBERG, J. Studies in African Linguistic Classification. New Haven: Compass Publishing Company, 1955.

GUILLET, G. Initiation a la tonalité et a la grammaire de la Langue Fon. Contonou, 1972.

GUTHRIE, M. Comparative bantu: An Introduction to the Comparative Linguistics and the Prehistory of the bantu Languages. Gregg International, 1968.

GUTHRIE, M. The Classification of the bantu Languages. Londres: Dawnsons, 1948.

GUTHRIE, M. Tone ranges in two-tone language (Lingala). In: GUTHRIE, M. Collected papers on bantu Linguistics. Teddington: Gregg Internetional Publishers Limited, 1970, cap. 2, p. 469-478. 
HALLIDAY, M. A. K. Introduction to Functional Grammar. Londres: Edward Arnold, 1994.

HALlidAY, M. A. K; MCINTOSH, A; STREVENS, P. The Linguistic Sciences and Language Teaching. Londres: Longman, 1964.

HAUGEN, E. The Norwegian Language in America: A study in bilingual behavior. Filadélfia: UP of Pennsylvania, 1953.

HAYES, B. Introductory Phonology. Oxford: Blackwell, 2008.

HAYMAN, L. M. Do all languages have word accent? In: HULST, H. (Org) Word Strees: Theorical and typological issues. Cambridge: University Press, 2014, cap. 2, p. 56-82. HEINE, B.; DEREK; N. African Languages: An Introduction. Cambridge, UK: Cambridge University Press, 2000.

HULST, H. The study of word accent and stress: past, presente, and future. In: HULST, H. (Org) Word Stress: Theorical and typological issues. Cambridge: University Press, 2014, cap. 1, p. 3-55.

HULST, H.; SMITH, N. Autosegmental studies on pitch accent. Dordrecht: Foris Publications, 1988.

HULST, H.; SMITH, N. The variety of pitch accent systems: Introduction. In: HULST, H.; SMITH, N. (Orgs) Autosegmental studies on pitch accent. Dordrecht: Foris Publications, 1988, cap. 1, p. 9-22.

JAKOBOVITS, L. A.; LAMBERT, W. E. Semantic satiation among bilinguals. Journal of Experimental Psychology, v. 62, p. 576-582, 1961.

JAKOBSON, R. Princípios de Fonologia Histórica. Tradução de Wilmar da Rocha D’angelis. Campinas, SP: Cut Nimuendaju, 2008.

JILKA, M. e MÕHLER, G. Intonational foreign accent: speech technology and foreign language teaching. Proceedings of ESCA Workshop on Speech Technology in Language Learning - Sweden: Marholmen Conference, 1998. 
JILKA, M. The contribution of intonation to the perception of foreign accent.Tese de Doutorado. Alemanha: Universidade de Stuttgart, 2000:

KISSEBERTH, C. W. Digo tonology. In: G. N. CLEMENTS; J. GOLDSMITH. (Orgs.) Autosegmental Studies in bantu Tone. Dordrecht: Foris Publications, 1984, p. 105-182.

KRASHEN, S. D. Principles and practice in second language acquisition. Oxford: Pergamon, 1982.

KRASHEN, S. D. Principles and practice in second language acquisition. Oxford: Pergamon Press, 1982.

KRASHEN, S. D. The input hypothesis. Londres: Longman, 1985.

KUHL, P. K.; IVERSON, P. Mapping the perceptual magnet effect for speech using signal detection theory and multidimensional scaling. Journal of the Acoustical Society of America, v. 97, 1995, p. 553-562.

KUKANDA, V. Diversidade lingüística em África. In: Africana Studia, no. 3. Porto, Faculdade de Letras da Universidade do Porto, 2000. Pp. 101-117.

LADD, D. R. Intonational phonology. Cambridge: Cambridge University, 2008. Ed. 2.

LADEFOGED, P. A course in phonetics. 3 ed. Boston: Heinle e Heinle, 1993. P. 289.

LADEFOGED, P. A phonetic study of West African languages. Cambridge: Cambridge University Press, 1968.

LADEFOGED, P. Elements of acoustic phonetics. Chicago: The University of Chicago Press, 1962.

LADEFOGED, P. Preliminaries to linguistic phonetics. Chicago: The University of Chicago Press, Midway Reprint, 1971. P. 122.

LADEFOGED, P. Vowels and consonants: an introduction to the sounds of languages. Massachusetts e Oxford: Blackwell, 2001. 
LADEFOGED, P; JOHNSON, K. A course in phonetics. $6^{\text {a }}$ ed. Massachusetts: Wadsworth Cengage Learning, 2011.

LADEFOGED, Peter; MADDIESON, Iam. The Sounds of the World's Languages. Cambridge, Massachuset: Blackwell, 1995.

LADO, R. Linguistics Across Cultures: Applied Linguistics for Language Teachers. Ann Arbor: University of Michigan Press, 1957.

LARSEN-FREEMAN, D. Chaos/complexity science and second language acquisition. Applied Linguistics, v. 18, 1997, 141-165.

LARSEN-FREEMAN, Diana; CAMERON, Lynne. Complex Systems and Applied Linguistics. Oxford University Press: Oxford, 2008.

LEE N.; SCHUMANN, J. H. The evolution of language and of the symbolosphere as complex adaptive systems. Paper presented at the conference of the American Association for Applied Linguistics, Arlington, March, 2003.

LEFFA, V. J. Metodologia do ensino de línguas. In BOHN, H. I.; VANDRESEN, P. Tópicos em lingüística aplicada: $O$ ensino de línguas estrangeiras. Florianópolis: Ed. da UFSC, 1988. p. 211-236.

LEHISTE, I. Suprasegmentals. Cambridge: MIT Press, 1970.

LIEBERMAN, P. Some acoustic correlates of word stress in American English. Massachussets: The MIT Press, 1976.

LONG, M. H. (Orgs) The handbook of second language acquisition. Oxford, Massachusetts e Victoria: Blackwell Publishing, 2003. Cap. 4, p. 63-103.

LUCENTE, L. Aspectos Dinâmicos da Fala e da Entoação no Português Brasileiro. Tese de doutorado. Unicamp, 2012.

LUCENTE, L. DaTo: Um sistema de notação entoacional do português brasileiro baseado em princípios dinâmicos. Ênfase no foco e na fala espontânea. Dissertação de Mestrado. Unicamp, 2008. 
MAJOR, R. C. Stress-timing in Brazilian Portuguese. Journal of Phonetics, 1981. 9(3): 343-352. MAJOR, R. C. Stress-timing in Brazilian Portuguese. Journal of Phonetics, 1981. 9(3): 343-352.

MASSINI-CAGLIARI, G. Acento e ritmo. São Paulo: Contexto, 1992.

MASSINI-CAGLIARI, G. Do poético ao linguístico no ritmo dos trovadores: três momentos da história do acento. Araraquara: FCL/Laboratório Editorial/UNESP, Cultura Acadêmica, 1999. P. 207.

MASSINI-CAGLIARI, G.; CAGLIARI, L. C. Fonética. Introdução à Lingüística: domínios e fronteiras, MUSSALIM, Fernanda e BENTES, Anna Christina (org.). São Paulo: Cortez, 2001.

MATTHIAS, J. The Contribution of Intonation to the Perception of Foreign Accent. Tese de doutorado. University of Stuttgart, 2000.

MATTOS E SILVA, Rosa Virgínia. (2002). Para a história do português culto e popular brasileiro: sugestões para uma pauta de pesquisa. In: ALKMIM, Tânia Maria (Org.). Para a história do português brasileiro. Volume III: novos estudos. São Paulo: Humanitas. p. 443464

MATTOSO, Kátia de Queirós. (1992). Bahia, século XIX: uma província no Império. Rio de Janeiro: Nova Fronteira

MAURER, Bruno. Les langues de scolarisation em Afrique francofone: enjeux et repères pour l'action. Agence Universitaire de la Francophonie. Unesco. Paris, 2010.

MCLAUGHLIN, B. Second-language acquisition in childhood. Hillsdale: Erlbaum, 1978.

MEEUSSEN, A. E. A note on permutation in Kpelle-Mende. African Language Studies, v. 6, 1965, p. 112-116.

MIRA MATEUS, M. H. Fonética, Fonologia e Morfologia do Português. Lisboa: Universidade Aberta, 1990.

MORAES, J. A. e Y. LEITE. Ritmo e velocidade da fala na estratégia do discurso: uma proposta de trabalho. In: Ilari, Rodolfo (org.) Gramática do Português Falado. Volume II: Níveis de Análise Lingüística. Campinas: Ed. da UNICAMP, 1992. pp. 65-77 
MUSSA, Alberto. (1991). O papel das línguas africanas na história do português do Brasil. Dissertação de Mestrado. Universidade Federal do Rio de Janeiro, Rio de Janeiro. NEMSER, W. Approximative systems of foreign language learners. International Review of Applied Linguistics, v. 9, 1971, p. 115-123.

NEWMAN, S. On the stress system of English. Word, v. 2, 1947, p. 171-87.

ODDEN, D. Phonology at the phrasal level in bantu. In: KATAMBA, F. bantu phonology and morphology. Munchen: Lincom Europa, 1995, cap. 3, p. 40-68.

ODDEN, D. Predictable tone systems in bantu. In: HULST, H.; SMITH, N. (Orgs) Autosegmental studies on pitch accent. Dordrecht: Foris Publications, 1988, cap. 12, p. 225251.

ODLIN, T. Cross-linguistic influence. In: DOUGHTY, C. J.; LONG, M. H. (Orgs) The handbook of second language acquisition. Oxford, Massachusetts e Victoria: Blackwell Publishing, 2003. Cap. 15, p. 436-486.

OKODOWA, B. Descrição preliminar de aspectos da fonologia e da morfologia do lembaama. Dissertação de Mestrado em Linguística - Faculdade de Filosofia, Letras e Ciências Humanas. Universidade de São Paulo: São Paulo, 2000.

OLTON, R. M. Semantic Generalization between Languages. Dissertação de mestrado. McGill University, 1960.

PIERREHUMBERT, J. B. Dissimilarity in the Arabic Verbal Roots. Proceedings of the North East Linguistics Society, v. 23, 1993, p. 367-381.

PIERREHUMBERT, J. B. Syllable Structure and Word Structure. In: KEATING, P. (Org.), Papers in Laboratory Phonology III. Cambridge: Cambridge University Press, 1994, p. $168-190$. . The phonology and phonetics of english intonation. Tese de doutorado. Massachusetts Institute of Technology, 1980.

PIKE, K. Phonetics: A critical analysis of phonetic theory and a technic for the practical description of sounds. 13. ed. Michigan: The University of Michigan Press, 1972. 
PIKE, K. Tone Languages: a technique for determining the number and type of pitch contrasts in a language, with studies in tonemic substitution and fusion. Ann Arbor: University of Michigan Press, 1948.

QUILIS, A. Fonética acústica de la lengua española. Madrid: Gredos, 1988.

REDDEN, J. E. A descriptive gramar of Ewondo. Carbondale: Department of Linguistics Southern Illinois University, 1979.

SAPIR, E. A linguagem: introdução ao estudo da fala. Tradução e apêndice de J. Mattoso Câmara Jr. São Paulo: Perspectiva, 1980.

SAPIR, E. Language: An Introduction to the Study of Speech. Courier Dover Publications, 2004

SAUSSURE, F. Curso de lingüística geral. São Paulo: Cultrix, 1972.

SCHUMANN, J. La adquisición de lenguas segundas: la hipótesis de la pidgnización. In: LICERAS, J.M. (Org) La adquisición de las lenguas extranjeras. Madrid: Visor, 1992.

SELIGER, H.; KRASHEN, S.; LADEFOGED, P. Maturational constraints in the acquisition of second language accent. Language Sciences, v. 36, p. 20-22, 1975.

SELIGMAN, C. G. Races of Africa. 1930.

SELINKER, L. Interlanguage. International Review of Applied Linguistics, v. 10, 1972, p. 209-231.

SELINKER, L. Interlanguage. International Review of Applied Linguistics, v. 10, n. 3, p. 209-231, 1972.

SILVA, A. H. P. Pela incorporação de informação fonética aos modelos fonológicos. Revista Letras, n. 60, p. 319-333, 2003.

SILVA, A. H. P. O estatuto da análise acústica nos estudos fônicos. Cadernos de Letras da UFF - Dossiê: Letras e cognição, nº41, p. 213-229, 2010. 
STÖRIG, H. J. A aventura das línguas: uma história dos idiomas do mundo. São Paulo: Melhoramentos, 2003. p. 165-175.

TARAllO, F.; ALCKMIM, T. Falares crioulos: línguas em contato. São Paulo: Ática, 1987. (Série Fundamentos, 15)

TEYSSIER, Paul (1997). História da língua portuguesa. São Paulo: Martins Fontes.

THELEN, E.; SMITH; L. A Dynamic Systems Approach to the Development of Cognition and Action. Cambridge: The MIT Press1994.

TRUBETZKOY, N. S. Principles of phonology. Tradução Christiane A. M. Baltaxe. Berkeley: University of California Press, 1969.

WALTHER, H. A aventura das línguas no Ocidente: origem, história e geografia. Trad. por Sérgio Cunha dos Santos. São Paulo: Mandarim, 1997. p. 317-361.

WARDHAUGH, R. An introduction to sociolinguistics. 2. ed. Oxford: Blackwell, 1992.

WEINREICH, U. Languages in Contact: findings and problems. Paris: The Hague, 1953.

WEINREICH, U.; LABOV, W.; HERZOG, M. I. Fundamentos empíricos para uma teoria da mudança lingüística. Tradução de Marcos Bagno. Revisão técnica de Carlos Alberto Faraco. Posfácio de Maria da Conceição A. de Paiva e Maria Eugênia Lamoglia Duarte. São Paulo: Parábola, 2006.

WEISS, Helga. Fonética articulatória: guia e exercícios. 3 ed. Brasília: SIL, 1988. 
ANEXO A 


\section{INSTITUTO DE CIENCIAS \\ HUMANAS / UNIVERSIDADE \\ DE BRASÍLIA / CAMPUS}

\section{PARECER CONSUBSTANCIADO DO CEP}

\section{DADOS DO PROJETO DE PESQUISA}

Título da Pesquisa: Aspectos fonológicos da aquisição do Português do Brasil por africanos francófonos

Pesquisador: Eugenia Magnolia da Silva Fernandes

Área Temática:

Versão: 2

CAAE: 20825813.6 .0000 .5540

Instituição Proponente: Instituto de Ciências Humanas

Patrocinador Principal: Financiamento Próprio

DADOS DO PARECER

Número do Parecer: 402.339

Data da Relatoria: 27/09/2013

Recomendações:

Conclusões ou Pendências e Lista de Inadequações:

Aprovado

Situação do Parecer:

Aprovado

Necessita Apreciação da CONEP:

Não

Considerações Finais a critério do CEP:

BRASILIA, 22 de Setembro de 2013

Assinador por:

Soraya Fleischer

(Coordenador) 


\section{ANEXO B}


\# SGdetector.psc

\# Script implemented by Plinio A. Barbosa (IEL/Unicamp) for detecting

\# stress group boundaries from production criteria, namely VV durations.Input: previously

\# segmented

\# VV intervals (TextGrid)

\# Please, do not distribute without the author's previous authorisation

\# The TextGrid and Reference-statistics (zaldo.TableOfReal) files need to be in the

\# same directory!!!

\# Date: May 27th, 2004

form Aquisição dos arquivos

word Arquivo_(TextGrid) FAbranchesRead

integer VvTier 1

choice Referencia: 1

button PB

button PE

endform

\# Lê o arquivo de referencia com as triplas (segmento, média, desvio-padrão) do locutor

\# Referencia. A variável nseg contém o número total de segmentos do arquivo de referência

Read from file... 'referencia\$'.TableOfReal

nseg $=$ Get number of rows

\#

\# Lê arquivo e TextGrid (desde q tenha o mesmo nome do arquivo de som

$\operatorname{arq} \$=$ arquivo $\$+"$. TextGrid"

Read from file... 'arq\$'

begin $=$ Get starting time

end $=$ Get finishing time

nselected $=$ Get number of intervals... 'vvTier'

nselected $=$ nselected -2

arqout $\$=$ arquivo $\$+$ "dur" + ".txt" 
filedelete 'arqout\$'

arqoutstrgrp\$ = arquivo $\$+$ "SG" + ".txt"

filedelete 'arqoutstrgrp\$'

fileappend 'arqout\$' \% Segmentos acusticos, duracao (ms) , z, z suav., fronteira 'newline\$'

fileappend 'arqoutstrgrp\$' \% Duração do grupo acentual | Número de sílabas 'newline\$'

select TextGrid 'arquivo\$'

initialtime $=$ Get starting point... 'vvTier' 2

for i from 1 to nselected

$\operatorname{adv}=\mathrm{i}+1$

nome $\$=$ Get label of interval... 'vvTier' 'adv'

itime $=$ Get starting point... 'vvTier' 'adv'

ftime $=$ Get end point... 'vvTier' 'adv'

dur $=$ ftime - itime

dur $=\operatorname{round}($ dur*1000)

tint $=$ Get starting point... 'vvTier' 'adv'

call zscorecomp 'nome\$' 'dur' 'tint'

dur'i' = dur

$z^{\prime} i^{\prime}=\mathrm{z}$

nome'i'\$ = nome\$

select TextGrid 'arquivo\$'

$\operatorname{adv}=\mathrm{i}+1$

endfor

$\operatorname{smz} 1=(2 * z 1+z 2) / 3$

$\operatorname{deriv} 1=\operatorname{smz} 1$

$\mathrm{smz} 2=(2 * \mathrm{z} 2+\mathrm{z} 1) / 3$

$\operatorname{deriv} 2=\operatorname{smz} 2-\operatorname{smz} 1$

$\mathrm{i}=3$

if $\operatorname{smz} 1<\mathrm{smz} 2$

$\operatorname{minsmz}=\operatorname{smz} 1$ 
máx.smz $=$ smz2

else

$\operatorname{minsmz}=\operatorname{smz} 2$

máx.smz = smz1

endif

while $\mathrm{i}<=$ (nselected-2)

del1 $=\mathrm{i}-1$

$\operatorname{del} 2=\mathrm{i}-2$

$\operatorname{adv} 1=\mathrm{i}+1$

$\operatorname{adv} 2=i+2$

smz'i' $=\left(5^{*} z^{\prime} i^{\prime}+3^{*} z^{\prime}\right.$ del $\left.1^{\prime}+3^{*} z^{\prime} \operatorname{adv} 1^{\prime}+z^{\prime} \operatorname{del} 2^{\prime}+1^{*} z^{\prime} \operatorname{adv} 2^{\prime}\right) / 13$

deriv'i' = smz'i' - smz'del1'

if smz'i' $<$ minsmz

$\operatorname{minsmz}=$ smz'i' $^{\prime}$

endif

if smz'i' > máx.smz

máx.smz $=$ smz'i'

endif

$\mathrm{i}=\mathrm{i}+1$

endwhile

tp1 $=$ nselected -1

tp2 $=$ nselected -2

smz'tp1' $=\left(3^{*} z^{\prime} \operatorname{tp} 1^{\prime}+z^{\prime} \operatorname{tp} 2^{\prime}+z^{\prime}\right.$ nselected' $) / 5$

deriv'tp1' = smz'tp1' - smz'tp2'

if smz'tp1'< minsmz

$\operatorname{minsmz}=\operatorname{smz}^{\prime} t \mathrm{t} 1^{\prime}$

endif

if smz'tp1' > máx.smz

máx.smz = smz'tp1' 
endif

smz'nselected' $=\left(2^{*} z^{\prime}\right.$ nselected' $+z^{\prime}$ tp $\left.1^{\prime}\right) / 3$

deriv'nselected' $=$ smz'nselected' - smz'tp1'

if smz'nselected' $<$ minsmz

minsmz $=$ smz'nselected'

endif

if smz'nselected' > máx.smz

máx.smz = smz'nselected'

endif

tempfile\$ = "temp.TableOfReal"

filedelete 'tempfile\$'

fileappend 'tempfile\$' File type = "ooTextFile short" 'newline\$'

fileappend 'tempfile\$' "TableOfReal" 'newline\$'

fileappend 'tempfile\$' 'newline\$'

fileappend 'tempfile\$' 2 'newline\$'

fileappend 'tempfile\$' columnLabels []: 'newline\$'

fileappend 'tempfile\$' "position" "smoothed z" 'newline\$'

tpp $=$ nselected +2

fileappend 'tempfile\$' 'tpp' 'newline\$'

time $=$ initialtime

fileappend 'tempfile\$' row[1]: "0" 0.00 .0 'newline\$'

boundcount $=0$

sdur $=0$

ssyl $=0$

sdurSG $=0$

$\operatorname{svar}=0$

for i from 1 to nselected

tempsmz $=$ smz'i'

tpnome $\$=$ nome'i'\$ 


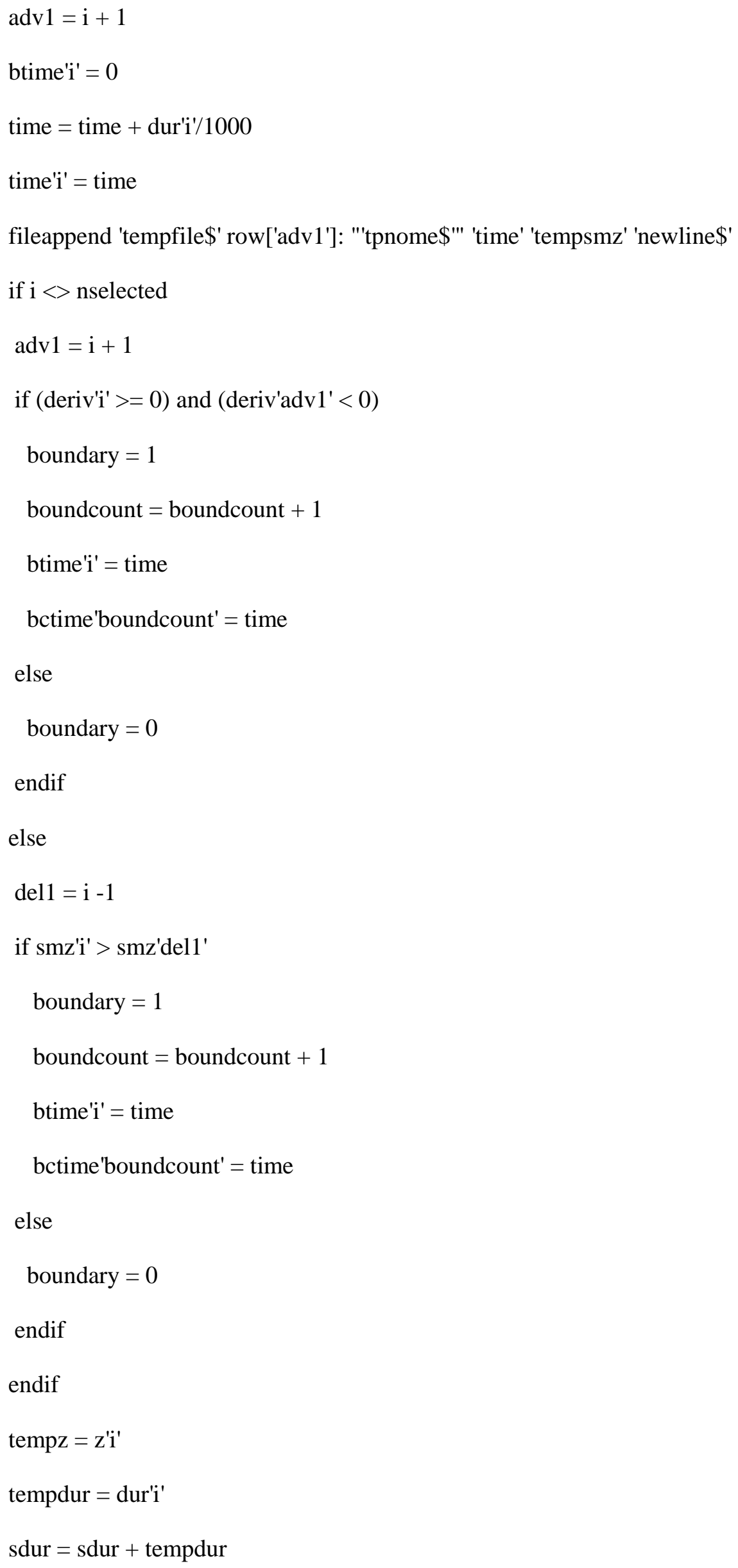


sdurSG $=$ sdurSG + tempdur

$\operatorname{ssyl}=\operatorname{ssyl}+1$

fileappend 'arqout\$' 'tpnome\$' 'tempdur' 'tempz:2' 'tempsmz:2' 'boundary' 'newline\$'

if boundary $==1$

fileappend 'arqoutstrgrp\$' 'sdurSG' 'ssyl' 'newline\$'

sdurSG $=0$

$\operatorname{ssyl}=0$

endif

endfor

meandur $=$ sdur/nselected

for i from 1 to nselected

svar $=$ svar $+(\text { dur'i' }- \text { meandur })^{\wedge} 2$

endfor

stddevdur $=\operatorname{sqrt}(\operatorname{svar} /($ nselected -1$))$

fileappend 'arqout\$' Média e desvio-padrão: 'meandur:0' 'stddevdur:0' 'newline\$'

tp $=\mathrm{i}+1$

fileappend 'tempfile\$' row['tp']: "X" 'end' 0 'newline\$'

select all

Remove

Black

Axes... 0101

for i from 1 to nselected - 1

tm = time'i'/time'nselected'

smzz $=$ smz'i'/máx.smz

$\mathrm{j}=\mathrm{i}+1$

tmnext $=$ time'j'/time'nselected'

smzznext $=$ smz'j' 1 máx.smz

Draw line... 'tm' 'smzz' 'tmnext' 'smzznext'

endfor 
\# Write a TextGrid with the stress group boundaries

fileout $\$$ = arquivo $\$+$ "2.TextGrid"

filedelete 'fileout\$'

fileappend 'fileout $\$$ ' File type = "ooTextFile short" 'newline\$'

fileappend 'fileout\$' "TextGrid" 'newline\$'

fileappend 'fileout\$' 'newline\$'

fileappend 'fileout\$' 'begin' 'newline\$'

fileappend 'fileout\$' 'end' 'newline\$'

fileappend 'fileout\$' <exists> 'newline\$'

fileappend 'fileout\$' 1 'newline\$'

fileappend 'fileout\$' "IntervalTier" 'newline\$'

fileappend 'fileout\$' "StressGroups" 'newline\$'

fileappend 'fileout\$' 'begin' 'newline\$'

fileappend 'fileout\$' 'end' 'newline\$'

tmp $=$ boundcount +2

fileappend 'fileout\$' 'tmp' 'newline\$'

fileappend 'fileout\$' 0.00 'newline\$'

fileappend 'fileout\$' 'initialtime' 'newline\$'

fileappend 'fileout\$' "' 'newline\$'

temp $=$ initialtime

for i from 1 to boundcount

fileappend 'fileout\$' 'temp' 'newline\$'

temp $=$ bctime'i'

fileappend 'fileout\$' 'temp' 'newline\$'

fileappend 'fileout\$' "" 'newline\$'

endfor

fileappend 'fileout\$' 'temp' 'newline\$'

fileappend 'fileout\$' 'end' 'newline\$'

fileappend 'fileout\$' "' 'newline\$' 
\#\#

$\operatorname{arqgrid} 1 \$=$ arquivo $\$+$ ".TextGrid"

$\operatorname{arqgrid} 2 \$=$ fileout $\$$

Read from file... 'arqgrid $1 \$$ '

Read from file... 'arqgrid $2 \$$ '

select all

Merge

\#\#

procedure zscorecomp nome $\$$ dur tint

sizeunit = length $($ nome $\$)$

sumofmeans $=0$

sumofvar $=0$

$\mathrm{cpt}=1$

while cpt $<=$ sizeunit

$\mathrm{nb}=1$

terminate $=0$

$\mathrm{k}=1$

$\operatorname{seg} \$=\operatorname{mid} \$($ nome $\$, \mathrm{cpt}, 1)$

if $\mathrm{cpt}<$ sizeunit

if $\operatorname{mid} \$($ nome $\$, c p t+1,1)==" h "$ or $\operatorname{mid} \$($ nome $\$, c p t+1,1)==" N "$

$\mathrm{nb}=\mathrm{nb}+1$

$\operatorname{seg} \$=\operatorname{seg} \$+\operatorname{mid} \$($ nome $\$, \operatorname{cpt}+1,1)$

endif

if $(\mathrm{cpt}+\mathrm{nb}<=$ sizeunit $)$

$\operatorname{tp} \$=\operatorname{mid} \$($ nome $\$, \mathrm{cpt}, 1)$

call isvowel 'tp\$'

if $((\operatorname{mid} \$($ nome $\$, c p t+n b, 1)=" I ")$ or $(\operatorname{mid} \$($ nome $\$, c p t+n b, 1)=" U "))$ and truevowel

$\operatorname{seg} \$=\operatorname{seg} \$+\operatorname{mid} \$($ nome $\$, \operatorname{cpt}+\mathrm{nb}, 1)$

$\mathrm{nb}=\mathrm{nb}+1$ 


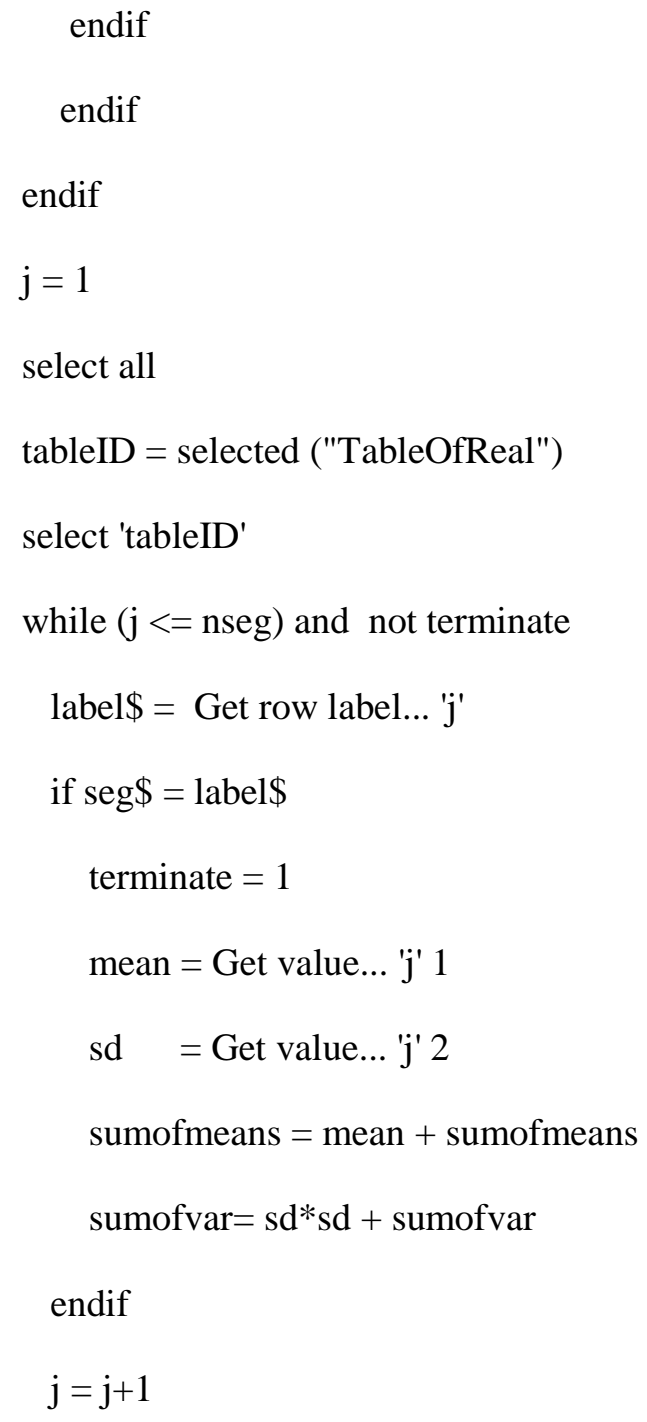


...or temp $\$=" \mathrm{~A} "$ or temp $\$=" \mathrm{O} "$ or temp $\$=" \mathrm{U} "$

truevowel $=1$

endif

endproc 
APÊNDICE A 


\section{TERMO DE CONSENTIMENTO LIVRE E ESCLARECIDO}

Você está sendo convidado a participar da pesquisa "Aspectos fonológicos na aquisição do Português Brasileiro por africanos francófonos" de responsabilidade de Eugênia Magnólia da Silva Fernandes, aluna de doutorado da Universidade de Brasília. O objetivo desta pesquisa é identificar e analisar as interferências das línguas africanas e da língua francesa no processo de aprendizagem do português por africanos. Assim, gostaria de consultá-lo(a) sobre seu interesse e disponibilidade de cooperar com a pesquisa.

Você receberá todos os esclarecimentos necessários antes, durante e após a finalização da pesquisa, e lhe asseguro que o seu nome não será divulgado, sendo mantido o mais rigoroso sigilo mediante a omissão total de informações que permitam identificá-lo(a). Os dados provenientes de sua participação na pesquisa, tais como questionários, entrevistas, fitas de gravação ou filmagem, ficarão sob a guarda do pesquisador responsável pela pesquisa.

A coleta de dados será realizada por meio de gravações de voz guiadas por leituras de pequenos textos, descrição de imagens e relatos de histórias. É para estes procedimentos que você está sendo convidado a participar. Sua participação na pesquisa não implica em nenhum risco ou análise de proficiência em língua portuguesa.

Espera-se com esta pesquisa contribua para estudantes africanos interessados em aprender o português do Brasil e que tenham como objetivo a aprovação com nível satisfatório no Exame Celpe-Bras (Certificado de Proficiência em Língua Portuguesa para Estrangeiros).

Sua participação é voluntária e livre de qualquer remuneração ou benefício. Você é livre para recusar-se a participar, retirar seu consentimento ou interromper sua participação a qualquer momento. A recusa em participar não irá acarretar qualquer penalidade ou perda de benefícios.

Se você tiver qualquer dúvida em relação à pesquisa, você pode me contatar através do telefone (61)8251-0040 ou pelo e-mail lia.unb@gmail.com.

A equipe de pesquisa garante que os resultados do estudo serão devolvidos aos participantes por meio da divulgação dos resultados obtidos que deverão fornecer subsídios para o ensino de português para estrangeiros, podendo ser publicados posteriormente na comunidade científica. 
Este projeto foi revisado e aprovado pelo Comitê de Ética em Pesquisa do Instituto de Ciências Humanas da Universidade de Brasília - CEP/IH. As informações com relação à assinatura do TCLE ou os direitos do sujeito da pesquisa podem ser obtidos através do e-mail do CEP/IH cep_ih@unb.br.

Este documento foi elaborado em duas vias, uma ficará com o(a) pesquisador(a) responsável pela pesquisa e a outra com o senhor(a).

Assinatura do Participante

Assinatura do Pesquisador 
APÊNDICE B 


\section{FICHA DE IDENTIFICAÇÃO DO COLABORADOR}

Pesquisa de Doutorado: "Aspectos fonológicos na aquisição/aprendizagem do Português Brasileiro por africanos francófonos"

Doutoranda: Eugênia Magnólia da Silva Fernandes

Orientadora: Daniele Marcelle Grannier

Nome:

Sexo: ( ) Feminino ( ) Masculino

Data de nascimento:

Nacionalidade:

Língua materna:

Línguas africanas que fala (por ordem de uso):

Línguas estrangeiras que fala (por ordem de proficiência):

Há quanto tempo no Brasil?

Onde e como aprendeu português?

Convivia e/ou convive com brasileiros?

Por que veio ao Brasil?

- Local e data do preenchimento da ficha:

Brasília, de de 
APÊNDICE C 


\section{Aspectos fonológicos da aquisição \\ do português brasileiro por africanos francófonos}

Pesquisadora

Eugênia Fernandes

Universidade de Brasília

\section{Esclarecimentos}

Você está colaborando para uma pesquisa da Universidade de Brasília (UnB) com foco no ensino da pronúncia do Português Brasileiro a africanos francófonos. $\mathrm{O}$ objetivo da coleta de dados, por meio das gravações, é encontrar as principais interferências da sua língua materna e da língua francesa no português brasileiro. Dessa forma, pretende-se criar estratégias para ajudar a lidar com essas interferências.

Para começar, leia o enunciado abaixo em voz alta. Quando terminar, passe para os próximos slides de faça o mesmo.

A proposta da pesquisa não é julgar a pronúncia dos colaboradores como certa ou errada, mas apenas identificar características de pronúncia. Então, não se preocupe em monitorar sua fala.

Leia espontaneamente, da maneira como você usa o português no seu dia a dia.

Os irmãos sempre brigam pra assistir televisão.

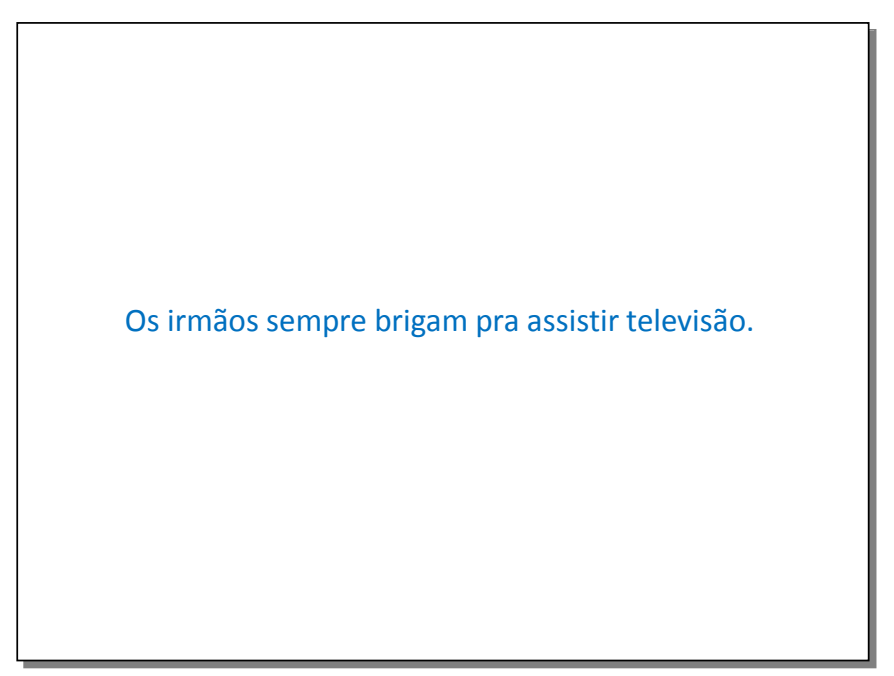

Eles estavam em casa esperando a mãe chegar com as roupas molhadas.

Eu já tinha pedido pra ela colocar as coisas no lugar, mas não adianta, ela não me obedece. 

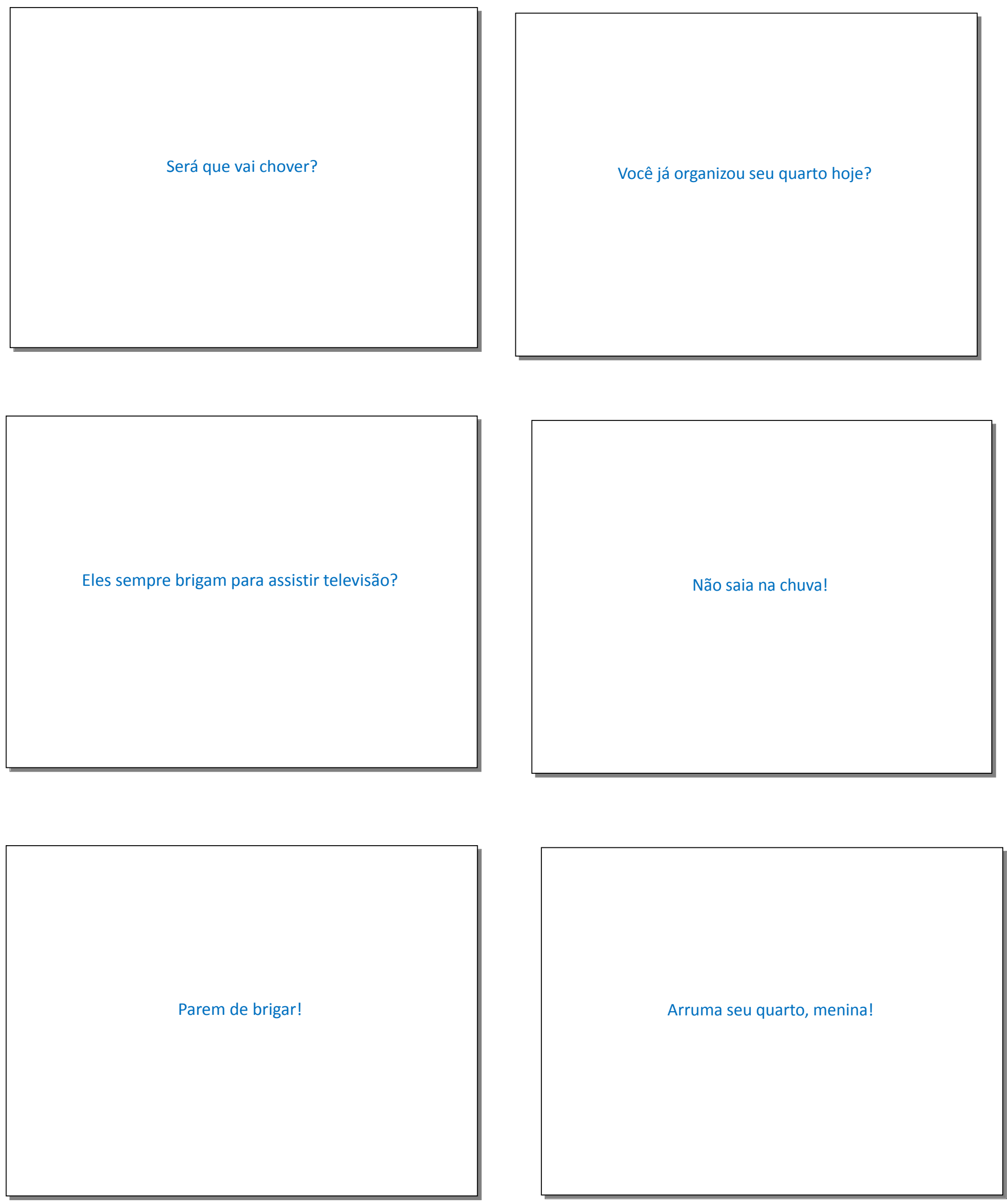

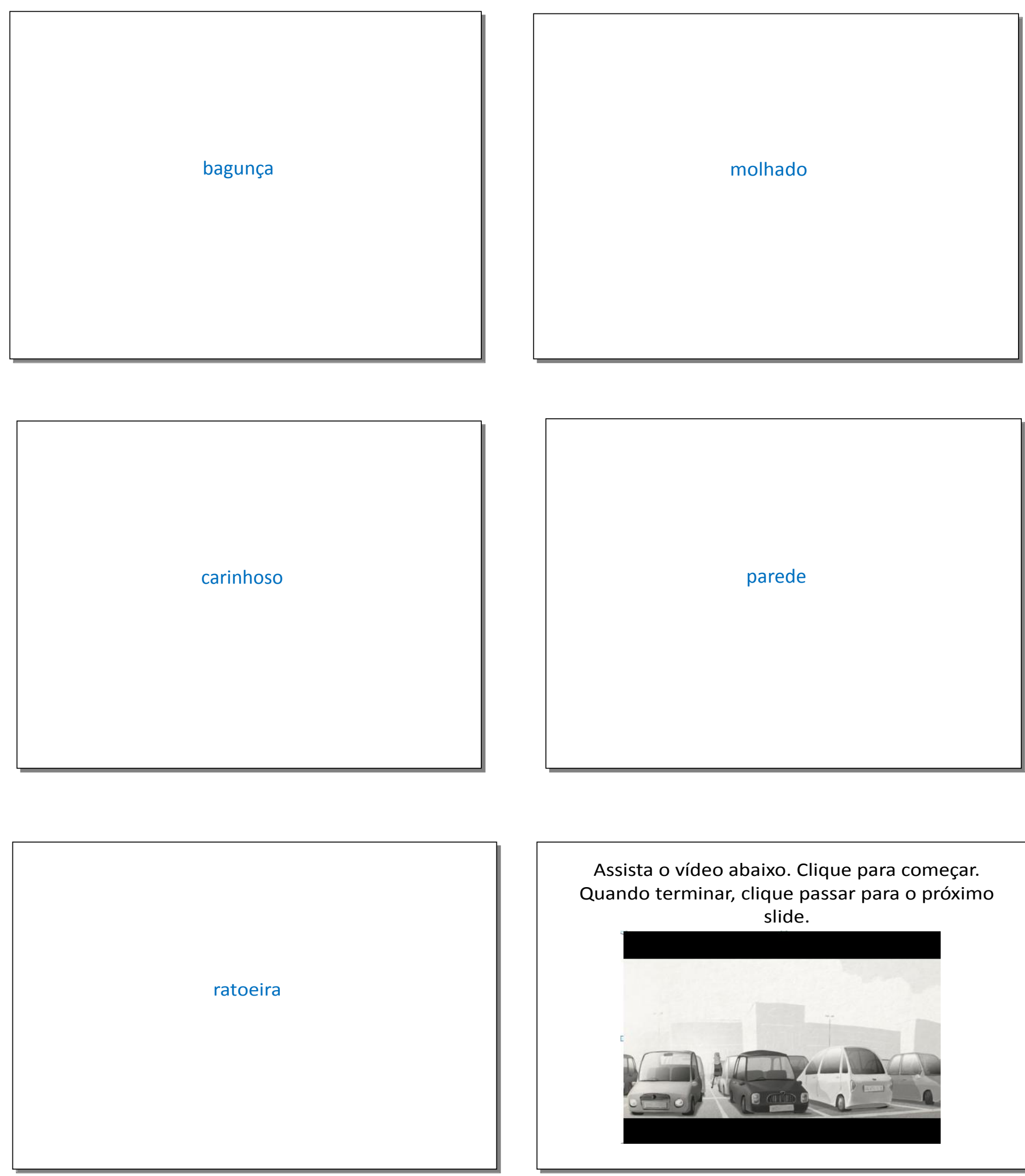

Assista o vídeo abaixo. Clique para começar. Quando terminar, clique passar para o próximo slide.

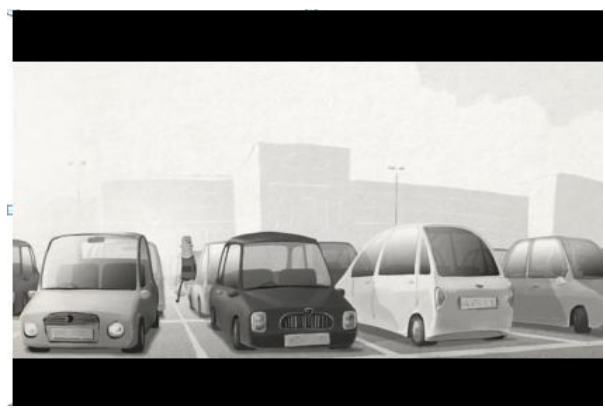


Leia a palavra abaixo. Faça o mesmo nos próximos slides.

\section{Organização}

Conte a história que aconteceu no vídeo.

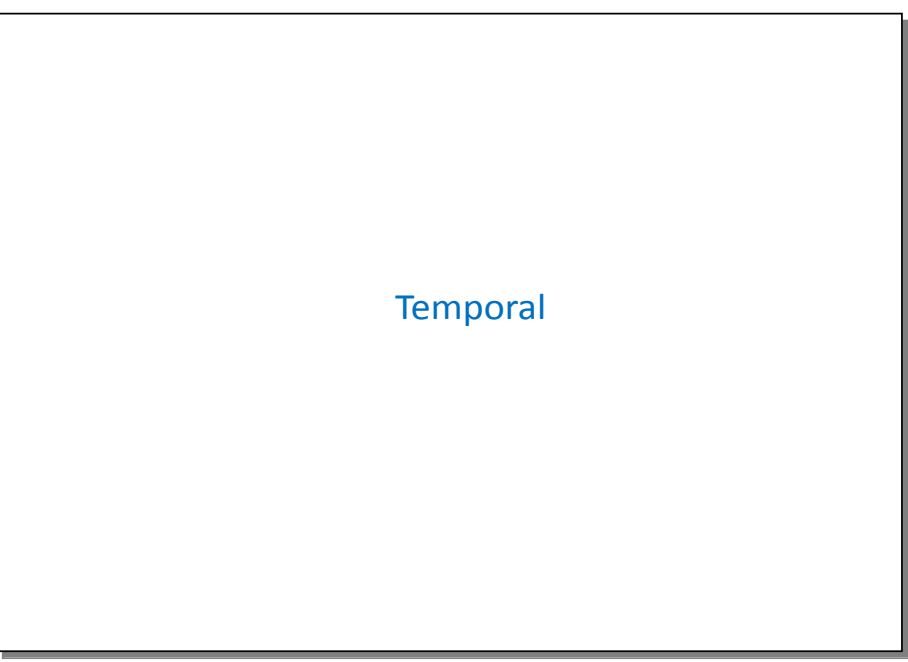

Assista o vídeo abaixo. Clique para começar. Quando terminar, clique passar para o próximo slide.

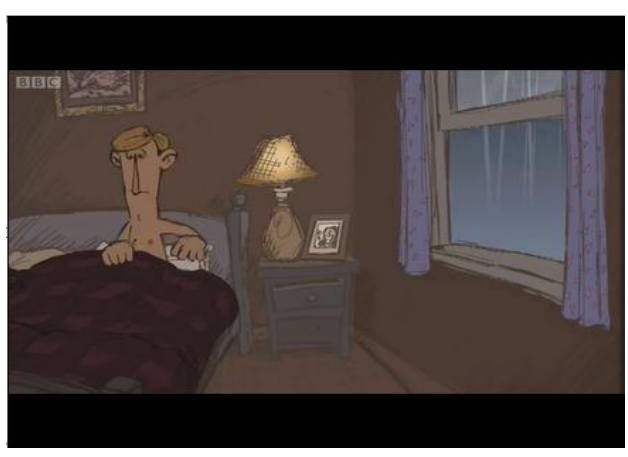

Eles gostam de chocolate? vídeo. 

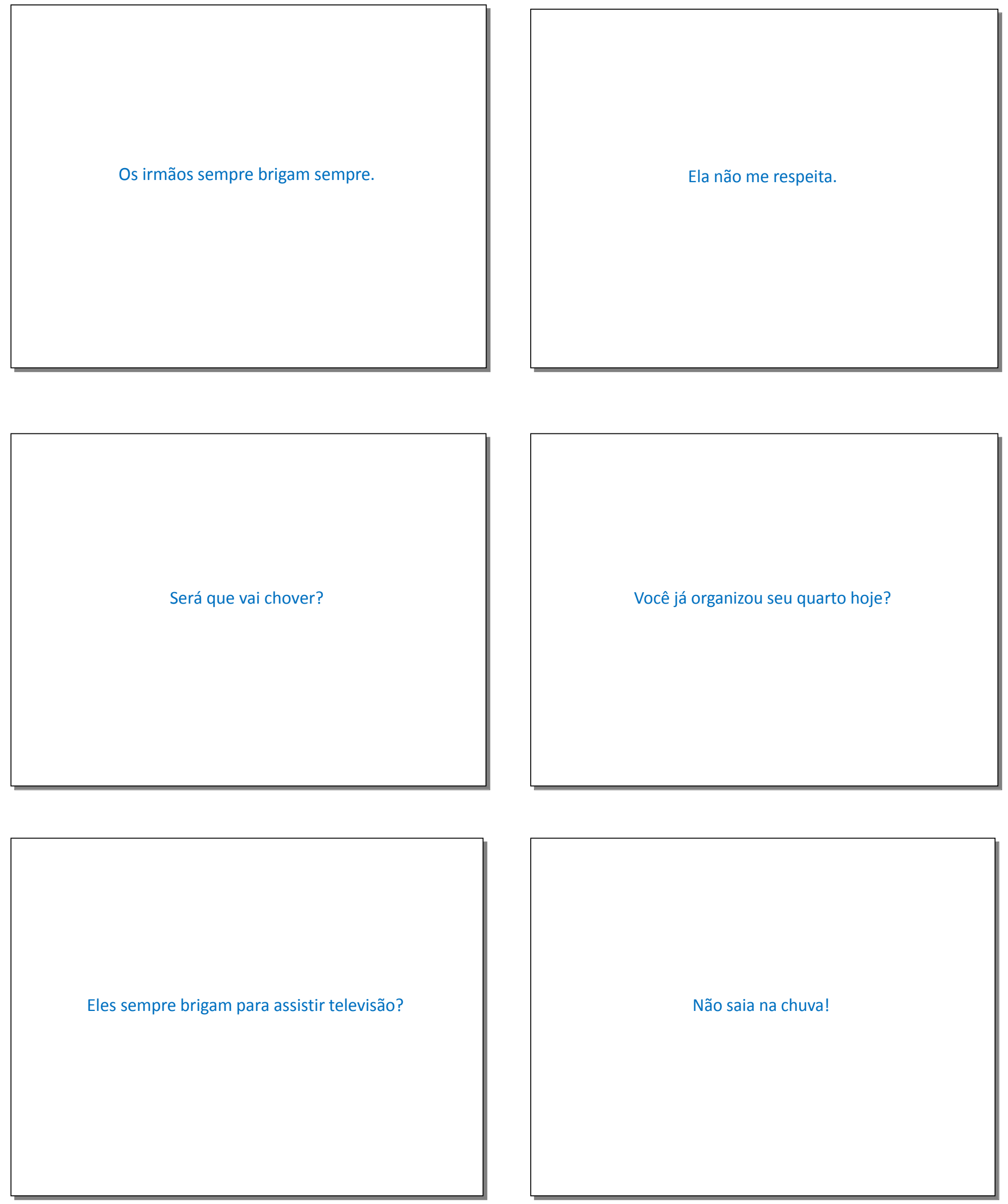
Parem de brigar!

Larga o emprego!

Quantos dias tem dezembro?
Arruma seu quarto!

Um rapaz larga o emprego.

Quem vai trocar a roupa? 
Quando começa a partida?

Me dá água, por favor!
Me dá água, por favor!

\section{Muito obrigada!}

Você receberá posteriormente o convite para participar da apresentação da pesquisa com a qual colaborou. Dessa forma, poderá ver as contribuições para aqueles que são africanos francófonos e têm interesse em aprender o Português Brasileiro.

Sua participação foi muito importante! 